UNIVERSIDADE DE SÃO PAULO

FACULDADE DE ECONOMIA ADMINISTRAÇÃO E CONTABILIDADE DEPARTAMENTO DE ADMINISTRAÇÃO PROGRAMA DE PÓS-GRADUAÇÃO EM ADMINISTRAÇÃO

DETERMINANTES DO INVESTIMENTO EXTERNO DIRETO EM TERRAS NOS PAÍSES EM DESENVOLVIMENTO

Leandro Simões Pongeluppe

Orientadora: Prof ${ }^{\mathrm{a}}$. Dr ${ }^{\mathrm{a}}$. Maria Sylvia Macchione Saes

SÃO PAULO

2013 
Prof. Dr. João Grandino Rodas

Reitor da Universidade de São Paulo

Prof. Dr. Reinaldo Guerreiro

Diretor da Faculdade de Economia, Administração e Contabilidade

Prof. Dr. Adalberto Américo Fischmann

Chefe do Departamento de Administração

Prof. Dr. Lindolfo Galvão de Albuquerque Coordenador do Programa de Pós-Graduação em Administração 


\section{DETERMINANTES DO INVESTIMENTO EXTERNO DIRETO EM TERRAS NOS PAÍSES EM DESENVOLVIMENTO}

Dissertação apresentada ao Departamento de Administração da Faculdade de Economia, Administração e Contabilidade da Universidade de São Paulo como requisito para obtenção do título de Mestre em Ciências.

Orientadora: Prof ${ }^{a}$. Dra . Maria Sylvia Macchione Saes

Versão Corrigida

(versão original disponível na Faculdade de Economia, Administração e Contabilidade)

\section{SÃO PAULO}




\section{FICHA CATALOGRÁFICA}

Elaborada pela Seção de Processamento Técnico do SBD/FEA/USP

\section{Pongeluppe, Leandro Simões}

Determinantes do investimento externo direto em terras nos países em desenvolvimento / Leandro Simões Pongeluppe. - São Paulo, 2013.

$87 \mathrm{p}$.

Dissertação (Mestrado) - Universidade de São Paulo, 2013.

Orientador: Maria Sylvia Macchione Saes.

1. Investimentos estrangeiros 2. Economia institucional 3. Vantagem competitiva 4.Países em desenvolvimento I. Universidade de São 


\section{AGRADECIMENTOS}

Certamente em apenas uma página não cabem todos os agradecimentos que deveriam ser prestados pela realização desta dissertação. Mas, ainda que de forma breve, espero transmitir a todos aqui citados meu sincero agradecimento pela ajuda, força e amizade.

Agradeço primeiramente a Deus e a São Jorge por me guiarem e por iluminarem meus caminhos!

À minha mãe por me ensinar o valor que tem a educação em nossas vidas, e a ter flexibilidade para contornar as adversidades do caminho.

Ao meu pai por me ensinar a ter firmeza em minhas decisões e a ter determinação para correr atrás de meus sonhos.

A meu avó José (em memória) e a meu tio Werno por me ensinarem o valor e a importância que o trabalho duro tem na vida de um homem. Obrigado por seu exemplo de vida.

À minha família. Em especial, à minha tia Maria Luiz quem sempre torceu por mim.

À minha orientadora Profa. Sylvia Saes (a quem tenho a honra de chamar de minha "segunda mãe") pela amizade e por acreditar em mim. Obrigado por sempre me ouvir e por me ajudar a crescer e aprender mais a cada dia como pessoa e como pesquisador.

Ao Prof. Sérgio G. Lazzarini (a quem tenho a honra de chamar de "coach") pela amizade e pela confiança. Obrigado pelas oportunidades que me deu e por me mostrar que com garra é possível vencer, mesmo vindo de uma origem humilde.

Aos professores Carlos Eduardo Carvalho, Luiz Mesquita e Marco Antônio dos Santos. Obrigado por me incentivarem a tentar algo novo e a sair de minha "zona de conforto".

Ao Prof. Bastiaan Philip Reydon pelas recomendações e conselhos dados durante a banca de qualificação. Obrigado pelo incentivo à realização deste trabalho.

Ao Prof. Flávio Saes por sempre se preocupar em me enviar notícias e novidades sobre o tema de investimento estrangeiro em terras brasileiras. Obrigado pelo carinho e pela amizade.

Aos professores Decio Zylbersztajn, Fábio Mizumoto, Dirk Boehe, Rita Lima de Castro (esta em especial pelo apoio para a finalização deste trabalho), Hildo Meirelles, Sandro Cabral, Paulo Furquim, Ana Célia Castro, Vivian Lara, Roberta Souza, Rubens Nunes, Guilherme Fowler e Priscila Claro, com os quais tive a honra de trabalhar nestes últimos anos. Obrigado pelos ensinamentos.

Ainda no âmbito acadêmico, agradeço à CAPES (Coordenação de Aperfeiçoamento Pessoal de Nível Superior), pela bolsa a mim concedida para a realização do presente trabalho, e sem a qual não poderia ter me dedicado exclusivamente a este projeto. À Universidade de São Paulo, à Faculdade de Economia Administração e Contabilidade, e em especial ao CORS (Center for Organization Studies), por contribuir de maneira indelével para a minha evolução, não apenas como estudante, mas também como pessoa. 
A meus amigos Kassia Watanabe, Eduardo Leão, Rubia Rinaldi Leão, Gustavo Toshiaki e Ellen Aabo, os quais possibilitaram que a viagem a Moçambique fosse realizada com sucesso, permitindo que o entendimento sobre o tema aumentasse consideravelmente. Obrigado por seu apoio e amizade.

A todos entrevistados nesta pesquisa, por sua paciência e atenção a mim prestadas. Obrigado por seu testemunho e por sua colaboração. Em especial, agradeço ao advogado Samuel Araújo e ao deputado federal Homero Pereira que me ajudaram tão gentilmente.

A meus amigos do CORS e do PENSA, Nobuiuki Ito, Paula Schnaider (em especial, obrigado pelo grande apoio para a melhoria do trabalho), Gabriela Jardim, Sara Gurfinkel, Mariana Granziera, Bruno Perosa, Raquel Zanon, Bruna Avellan, Fausto Makishi, Eder Carvalho, Fabio Dolnikoff, Tiago Carvalho, Anders Fredriksson, Carol Moron, Fernando Kolya, Carol Foscaches, Caroline Gonçalves, Fernanda Lemos, Edvanilcia Genari ("Neca"), Francisco Costa e Bruno Varella. A este último meu agradecimento especial, pois graças a ele a ao Antônio Carlos ("AC") conheci este grupo de pesquisa. Obrigado a todos pelas longas conversas, conselhos e ensinamentos. Este trabalho é de vocês também (eventuais erros são de minha responsabilidade).

A meus amigos da graduação, Yasser Saleh, George Abdul-Hak, Laura Martins, Kary Visoto, Wu Yunjia, Marcelo Domingues, Vinícius Lima e Renan Alves os quais sempre me incentivaram e me deram força para continuar a luta.

Por fim, obrigado a todos que de alguma forma me ajudaram a concluir mais este sonho! Vamos em busca do próximo!

Força e Honra!!! 


\section{RESUMO}

\section{DETERMINANTES DO INVESTIMENTO EXTERNO DIRETO EM TERRAS NOS PAÍSES EM DESENVOLVIMENTO}

Desde o final dos anos 2000, impulsionado pelo boom dos preços das commodities, o movimento de aquisição de terras por estrangeiros tem se acentuado nos países em desenvolvimento. Este estudo pretende responder quais são os condicionantes que determinam os Investimentos Externos Diretos (IED) em terras em alguns países e não em outros. Em termos teóricos, a abordagem da Nova Economia Institucional (NEI) argumenta que as instituições são importantes para as estratégias dos agentes econômicos e para o seu desempenho (NORTH, 1990). Já a Teoria Baseada em Recursos (TBR) afirma que os recursos são determinantes para a criação de rendas econômicas, por seu pontencial de gerarem vantagens competitivas (BARNEY, CLARK, 2007). Tendo em vista essas abordagens, esse estudo tem como hipótese que o ambiente institucional e a presença de recursos estratégicos influenciam o nível de Investimento Externo Direto em aquisição de terras nos países em desenvolvimento. Utilizando-se de análise estatística qualitativa comparativa e quantitativa verifica-se a relação entre o nível de IED aplicado nos países receptores, tendo em vista os seguintes condicionantes: direito de propriedade; nível de corrupção; liberdade de investimento; disponibilidade de terra agricultutável; e produtividade da terra. Para tanto, foram usados dados secundários de organizações internacionais, tais como: Food and Agriculture Organization (FAO), Banco Mundial; Conferência das Nações Unidas sobre Comércio e Desenvolvimento (UNCTAD); Organização para a Cooperação e Desenvolvimento Econômico (OCDE) e Heritage Foundation - Wall Street Journal. Realizou-se também estudos mais aprofundados em dois países - Moçambique e Brasil - que vêm sendo escolhidos pelos investidores externos. Por fim, concluiu-se que o padrão de investimento nos países em desenvolvimento leva em conta, fundamentalmente, a garantia de direitos de propriedade e a diminuição da disponibilidade de terras nas localidades alvo de aplicações, mostrando que tanto a literatura institucional quanto a de recursos são relevantes na decisão de investimento, porém algumas de suas dimensões são mais importantes que outras.

Palavras-chave: Investimento Externo Direto, Nova Economia Institucional, Teoria Baseada em Recursos, Países em Desenvolvimento, Mercado de Terras. 


\section{ABSTRACT \\ DETERMINATS OF LAND FOREIGN DIRECT INVESTMENT IN DEVELOPING COUNTRIES}

Since the late 2000s, driven by boom of commodity prices, the movement of land acquisition by foreigners has been growing in developing countries. This study aims to answer what are the conditions that determine Foreign Direct Investment (FDI) in land in some countries and not in others. In theoretical terms, the approach of New Institutional Economics (NIE) argue that institutions are important to strategies of economic agents and their performance (NORTH, 1990). Resource-Based Theory (RBT) states that the resources are crucial to the creation of rents, by its pontencial of generating competitive advantages (BARNEY, CLARK, 2007). Given these approaches, this study has been hypothesized that the institutional environment and the presence of strategic resources influence the level of Foreign Direct Investment on land acquisition in developing countries. Using statistical qualitative comparison analysis and quantitative will be checked the relationship between the applied level of FDI in host countries, taking into consideration the following factors: property rights; level of corruption; investment freedom; avaiability of soil for agriculture use; and land pproductivity. Thus, we used secondary data from international organizations such as: Food and Agriculture Organization (FAO), World Bank, United Nations Conference on Trade and Development (UNCTAD), Organization for Economic Co-operation and development (OECD) and Heritage Foundation - Wall Street Journal. We also conducted further studies in two countries - Mozambique and Brazil - which has been choosed by foreign investors. Finnaly, it was concluded that the pattern of investment in developing countries, takes into account primarily the security of property rights and the decrease availability of land in the targeted locations of aplications, showing that both the institutional literature, as resources literature are relevant in the investment decision, but some of its dimensions are more important than others.

Keywords: Foreign Direct Investment, New Institutional Economy, Resource-Based Theory, Developing Countries, Land Market. 


\section{SUMÁRIO}

1. INTRODUÇÃO

2. A RACIONALIDADE DOS INVESTIMENTOS EM TERRAS: A NOVA ECONOMIA INSTITUCIONAL E A TEORIA BASEADA EM RECURSOS ......................................... 11

2.1 - A Nova Economia Institucional (NEI) ........................................................ 12

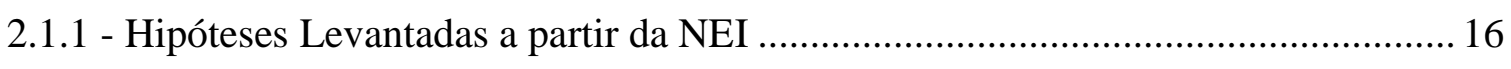

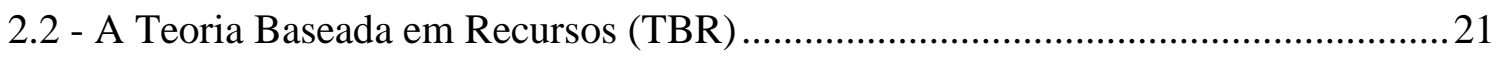

2.2.1 - A Terra Como Recurso Estratégico …............................................................. 27

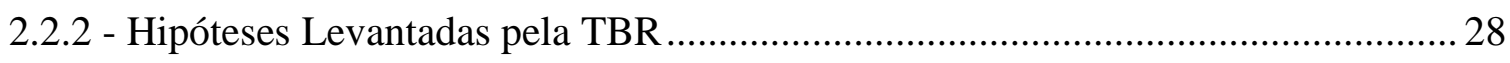

2.3 - Importância da Interação entre NEI e TBR .........................................................29

3. ANÁLISE APLICADA SOBRE OS DETERMINANTES DO INVESTIMENTO EXTERNO DIRETO NOS PAÍSES EM DESENVOLVIMENTO....................................... 32

3.1 - Análise Estatística Qualitativa e os determinantes do IED ......................................32

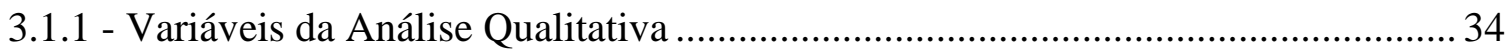

3.1.2 - Análise dos determinantes do IED em 2010 segundo a metodologia csQCA...... 40

3.2 - Análise Estatística Quantitativa e os determinantes do IED, 2000-2010 ................45

3.2.1 - Variáveis e Resultados do Modelo Quantitativo ................................................. 46

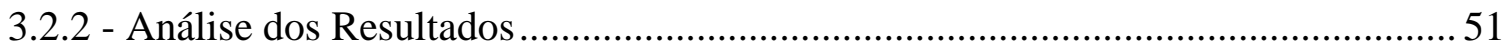

4. DUAS EXPERIÊNCIAS DE INVESTIMENTO EXTERNO DIRETO EM TERRAS ......53

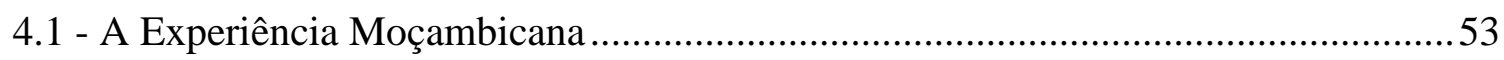

4.1.1 - Ambiente Institucional em Moçambique e os Investimentos em Terras............... 54

4.1.2 - Ambiente Institucional Moçambicano: A Visão dos Agentes Locais ..................... 56

4.1.3 - Considerações Finais sobre a Experiência Moçambicana ................................... 61

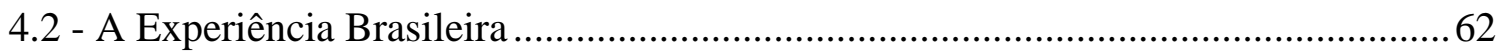

4.2.1 - Investimento Estrangeiro em Terras Brasileiras ................................................ 63

4.2.2 - Ambiente Institucional Brasileiro no Tangente a Terras ..................................... 65

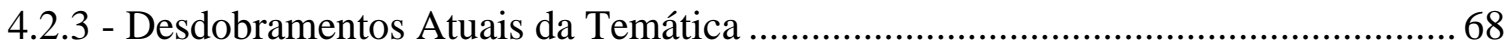




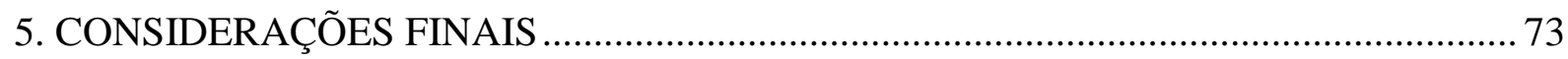

5.1 - Contribuições, Limitações e Sugestões para Estudos Futuros ................................... 77

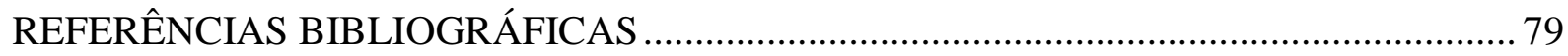

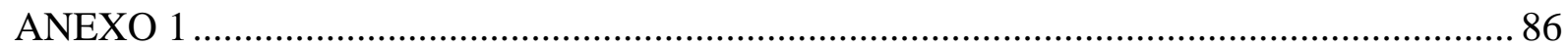




\section{LISTA DE TABELAS}

Tabela 1- Potencial disponibilidade de terras não-cultivadas em diferentes regiões ................ 38

Tabela 2 - Produtividade na produção de cereais das regiões ................................................ 40

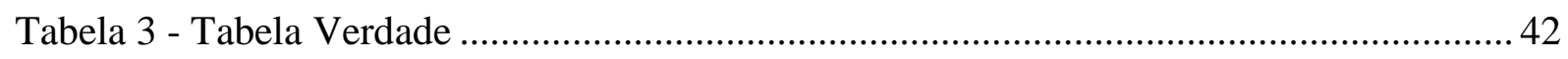

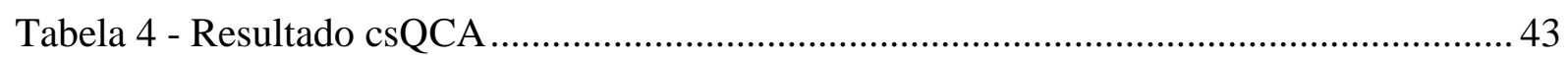

Tabela 5 - Resultado Modelos Painel de Efeito Fixo e Aleatório ........................................... 50

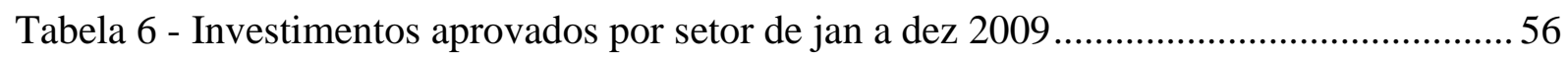

Tabela 7 - Fluxo de Investimentos Externos no Brasil por Setor (USD Milhões) .................... 65

Tabela 8 - Explicação para as Expressões Lógicas ............................................................... 87

\section{LISTA DE QUADROS}

Quadro 1 - Descrição das Variáveis do Estudo Qualitativo........................................................ 40

Quadro 2 - Descrição das Variáveis do Estudo Quantitativo................................................... 49

Quadro 3 - Hipóteses e Resultados das Análises ..................................................................... 76 


\section{LISTA DE FIGURAS}

Figura 1 - Índice de preço das commodities alimentícias (por mês) ….................................... 7

Figura 2 - Instituições e Organizações .............................................................................. 13

Figura 3 - Quatro pontos da dinâmica institucional segundo Aoki (2007) e possíveis relações 15

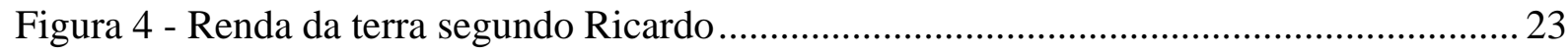

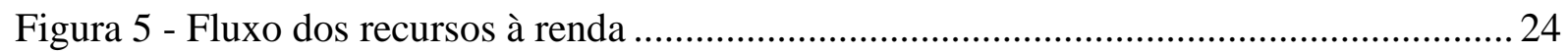

Figura 6 - Dinâmica e Hipóteses para o IED em Terras .......................................................... 31

Figura 7 - Desenho dos sistemas: mais semelhantes e mais diferentes .................................. 33

Figura 8 - Classificação dos países segundo indicador de Direitos de Propriedade ................. 36

Figura 9 - Classificação dos países segundo indicador de Ausência de Corrupção................. 36

Figura 10 - Classificação dos países segundo indicadores de Liberdade de Investimento ....... 37

Figura 11 - Área Colhida e Respectiva Produção de Cereais ................................................... 39

Figura 12 - Dados Dicotomizados no software TOSMANA ................................................. 41

Figura 13 - Evolução Comparativa EUA/Brasil sobre o Preço da Terra Agricultável............ 52

Figura 14 - Processo de aplicação de projeto e direito à terra em Moçambique.......................58

Figura 15 - Evolução dos Registros e Áreas em Mãos de Estrangeiros.................................... 64 


\section{INTRODUÇÃO}

Desde o início dos anos 2000, os países em desenvolvimento têm acolhido significativos aportes de Investimento Externo Direto (IED) na forma de aquisição de terras. Devido à contemporaneidade desse fenômeno, não há informações sistemáticas sobre o assunto, o que não impediu de ele ser objeto de muito debate tanto na mídia, quanto em organizações internacionais, tais como Banco Mundial (2010) e FAO(2012a, 2012b) ${ }^{1}$.

\section{O relatório: "Rising Global Interest in Farmland. Can It Yield Sustainable and Equitable}

Benefits?", um dos primeiros a tratar do tema, foi divulgado pelo Banco Mundial, em 2010.

De acordo com esse levantamento, só entre outubro de 2008 e agosto de 2009, 46,6 milhões de hectares teriam sido adquiridos por estrangeiros nos países em desenvolvimento, o que significa uma área superior a toda a região agricultável do Reino Unido, França, Alemanha e Itália, juntos. Nesse mesmo período, apenas no Brasil os investidores estrangeiros já teriam adquirido 3,6 milhões de hectares.

O levantamento também informa que os projetos são principalmente de grande porte; têm tamanho médio de 40.000 ha, sendo que um quarto deles envolve mais de 200.000 ha. ${ }^{2}$ Segundo o referido estudo, os investidores são concentrados em três categorias principais: (a) Grandes Corporações Multinacionais do Agronegócio ${ }^{3}$; (b) Fundos de Investimento ${ }^{4}$; e (c)

\footnotetext{
${ }^{1}$ De um lado, defende-se que os investimentos estrangeiros devem trazer lucros e crescimento para os países não desenvolvidos, de outro, argumenta-se que se trata de um novo colonialismo que levará a concentração da propriedade e lucro apenas para os investidores, sem desenvolver os países receptores dos investimentos. Por exemplo, ver: The Economist (THE CHINESE AND ARABS ARE BUYING POOR COUNTRIES' FARMS ON A COLOSSAL SCALE. BE WARY OF THE RESULTS, 2009), (BANCO MUNDIAL, 2010) e (FAO, 2012a, 2012b).

${ }^{2}$ Esses dados foram obtidos a partir de compilação de informações da mídia a partir do blog: farmalandgrab.org

3 Essas firmas conseguem coordenar toda a cadeia produtiva do(s) produto(s), gerando vantagens competitivas na produção. Podem-se citar exemplos como: a argentina El Tejar, que já é a maior produtora de soja do Brasil, com 673 mil toneladas plantadas em 220 mil hectares (HANNEMANN, 2011), e a indiana Karuturi Global Ltda, que recebeu concessão de 300 mil hectares, na Etiópia (DAVISON, 2011).

${ }^{4}$ Por terem acesso fácil ao mercado de crédito internacional, estes fundos vêm crescentemente investindo em terras, dada sua inerente liquidez, estabilidade (frente às crises econômicas), potencial na geração de valor futuro e baixa depreciação no mercado (REYDON, 1992). Como exemplo cita-se, o fundo Pharos Miro Agricultural Fund dos Emirados Árabes Unidos, constituído em uma joint venture com o fundo Miro Holding International (sediado em Londres), que investiu em 2009 U\$ 350 milhões na agricultura e tem como expectativa de retorno $25 \%$ em cinco anos (KHAN, 2009).
} 
Estados Nacionais ${ }^{5}$. Os países africanos têm apresentado maior participação em termos de área adquirida no total mundial. Dados apresentados no relatório da FAO (2012a) "Trends and Impacts of Foreign Investment in Developing Country Agriculture” mostram que entre 754 negócios envolvendo terras, 56,2 milhões de hectares estão localizados na África, 17,7 milhões hectares na Ásia e sete milhões de hectares na América (FAO, 2012a, p.5).

As motivações para a ocorrência desse fenômeno são bastante consensuais. A tendência de crescimento no preço das commodities alimentícias é uma delas. A Figura 1 mostra essa alta, ressaltando dois momentos importantes, 2008 e 2011, em que os aumentos foram intensificados devido a problemas climáticos. Esses eventos foram bastante destacados na mídia internacional em consequência da elevada insegurança alimentar de populações em diversos países (FOOD: THE SILENT TSUNAMI, 2008; WHATEVER HAPPENED TO THE FOOD CRISIS?, 2009).

De acordo com os especialistas, esta tendência de elevação não deve se modificar, implicando uma maior atratividade dos investimentos em países produtores ou potencialmente produtores de bens alimentícios (FAO, 2012a). Vale dizer que a alta dos preços dos combustíveis fósseis em 2007-2008 também aumentou a demanda por terras, gerando uma "competição" entre biocombustíveis e alimentos pela área agricultável, fato este que ocasionou um aumento ainda maior nos preços dos alimentos.

\footnotetext{
${ }^{5}$ Alguns países, notadamente a China, vêm realizando este tipo de investimento visando garantir acesso à terra para produção de alimentos no futuro. Um exemplo, publicado na mídia foi o plano do Estado chinês, em 2010, de investir cerca de U\$ 11 bilhões no Brasil no setor agrícola (CHINA COMPRA TERRAS NO BRASIL, 2010). Outro caso, também apresentado na mídia diz respeito às tratativas de acordo entre Coréia do Sul e Madagascar, que definia uma concessão de 1,3 milhões de hectares por 99 anos para a empresa coreana Daewoo (HEAD, 2009).
} 


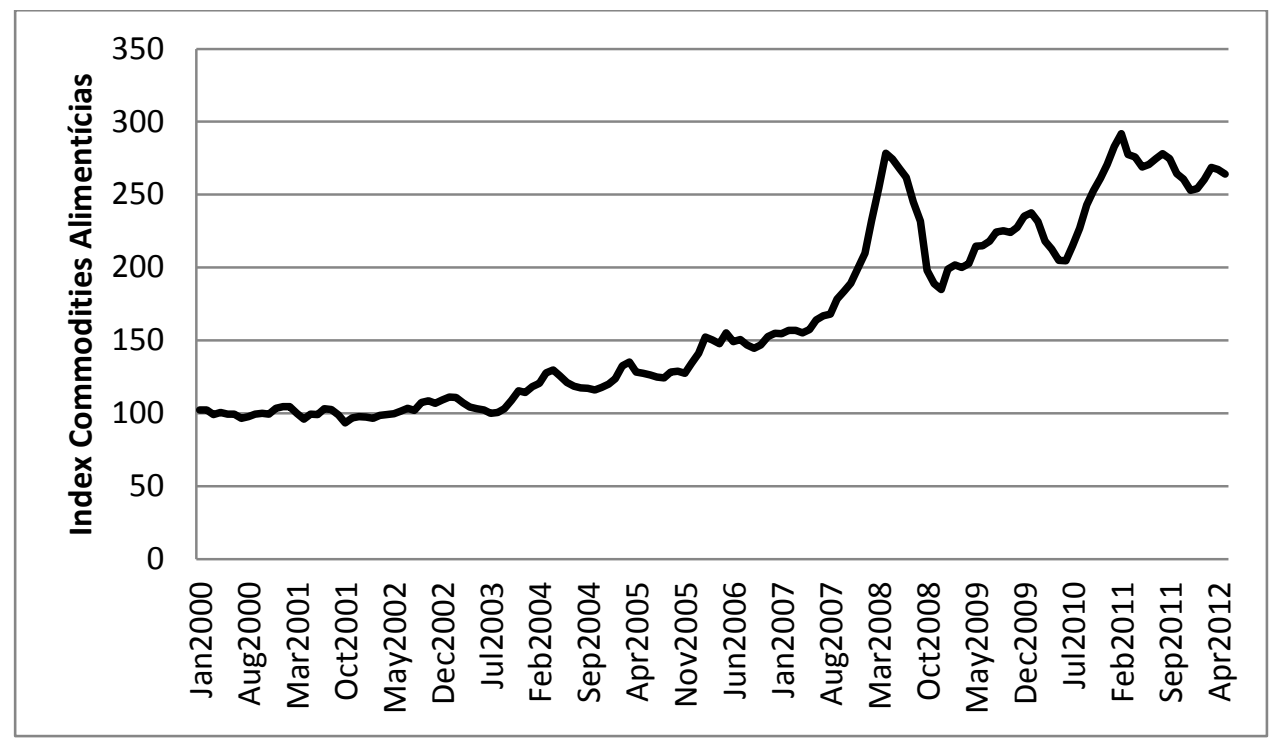

Figura 1 - Índice de preço das commodities alimentícias (por mês) Fonte: UNCTADStat $(2012, \mathrm{~s} / \mathrm{p}$.).

Outro fator considerado relevante para a elevação da procura por terras são as projeções de crescimento populacional. De acordo com estimativas da FAO-OCDE, em 2050 a população mundial será de aproximadamente nove a nove e meio bilhões de habitantes (OCDE, 2009). Considerando tal projeção com as perspectivas de aquecimento global, escassez de recursos hídricos e de solos agricultáveis ${ }^{6}$, potencializa-se a insegurança também na produção alimentícia e em sua capacidade de atender à crescente demanda por comida, sobretudo em localidades altamente povoadas como Europa, China e Índia.

Por fim, a crise econômica e financeira mundial que as economias desenvolvidas têm sofrido a partir dos anos 2008 têm, de forma semelhante, estimulado a busca por terras devido o potencial de liquidez, reserva de valor e capacidade de apreciação ao longo do tempo que a terra inerentemente detém (REYDON, 1992). Esse condicionante pode explicar, por exemplo, a motivação dos grandes fundos de investimentos na aquisição de terras em países estrangeiros, onde ela ainda tem um valor de mercado subestimado.

Tendo em vista as considerações apresentadas, que mostram a tendência do crescimento dos investimentos em terras nos países em desenvolvimento, pode-se pensar em duas categorias

\footnotetext{
${ }^{6}$ Presentes em relatórios da OCDE (Organização para a Cooperação e Desenvolvimento Econômico) e dos painéis do IPCC (Intergovernmental Panel on Climate Change), especificamente no painel AR4.
} 
de questões de pesquisa. Aquelas que tentam explorar a problemática da tomada de decisão de investimento ex-ante (ou seja, as motivações para a escolha do local do investimento) e as que estão interessadas no resultado desses investimentos ex post (ou seja, desempenho para os investidores e/ou para os países hospedeiros).

A questão de pesquisa que interessa a presente dissertação diz respeito à primeira categoria, já que ela possibilita uma discussão instigante sob a ótica da Nova Economia Institucional - NEI (NORTH, 1990) e da Teoria Baseada em Recursos - TBR (BARNEY, CLARK, 2007) quais sejam: por que alguns países, em especial, têm sido alvos dos investimentos estrangeiros? Qual o papel do ambiente econômico/institucional na decisão de investir? Por que países que têm rígidas restrições aos investimentos estrangeiros têm também apresentado um grande aporte de recursos na aquisição de terras por capital internacional? Qual o papel dos recursos (disponibilidade de terra /produtividade) na escolha dos investidores por uma determinada região/país? Sendo assim, a problemática central do presente estudo é responder:

\section{Quais os determinantes do investimento externo direto em terras nos países em desenvolvimento?}

O papel do ambiente institucional será investigado à luz da NEI principalmente a partir das ideias de North (1990), Alston, Eggertsson e North (1996), Aoki (2007), Brousseau e Raynaud (2007). Estes autores destacam de que forma as instituições vigentes condicionam a lógica de tomada de decisão econômica e determinam, por consequência, o desempenho das organizações. Para esses autores, a garantia de direitos de propriedade induz as organizações a investirem em atividades economicamente produtivas, visando à acumulação de capital. Nesse sentido, um sistema político-econômico "ideal" é aquele que estabelece uma estrutura de propriedade que maximize o produto econômico de uma sociedade. Ou seja, aquele que estabelece um sistema de propriedade bem definido e acompanhado de um aparato institucional eficaz no cumprimento das regras em vigor e no estabelecimento de salvaguardas aos investimentos realizados.

A partir da NEI surgem, por conseguinte, três hipóteses a serem verificadas:

h1: Direitos de Propriedade (Força Legal) bem definidos atraem maiores volumes de IED. h2: A Ausência de Corrupção (Força Política) atrai maiores volumes de IED. 
h3: A Liberdade de Investimento (Força Econômica) atrai maiores volumes de IED.

O papel dos recursos será abordado pela Teoria Baseada em Recursos (TBR). A TBR foi inicialmente proposta por Penrose (1959) e desenvolvida por Wernerfelt (1984, 1995), Barney (1991), Peteraf (1993), Barney e Clark (2007), dentre outros. Essa abordagem ressalta a importância existente no mercado de fatores, pois é a partir da posse de recursos valiosos, raros e inimitáveis que a firma obtém vantagens competitivas (VC). A TBR auxilia a entender como a terra, por ser um recurso estratégico, é vista como uma importante fonte de Vantagens Competitivas Sustentáveis (VCS) para as firmas. Para a TBR a visão da terra como "ativo especial" ocorre não apenas por sua inerente liquidez (REYDON, 1992), mas principalmente pelo potencial de geração de rendas ricardianas, decorrente de sua exploração produtiva.

A partir da TBR surgem, por conseguinte, duas hipóteses a serem verificadas:

h4: A maior Disponibilidade de Terras Agricultáveis atraem maiores volumes de IED.

h5: Quanto menor for a Produtividade da Terra (rendimento), maior é o potencial de atração de IED.

Para tratar as cinco hipóteses da pesquisa serão realizadas dois tipos de análises. A primeira trata a variável IED em função de variáveis institucionais (Direitos de Propriedade; Ausência de Corrupção e Liberdade de Investimentos) e de recursos (Disponiblidade de Terras Agricultavéis e Produtividade da Terra), a partir da metodologia de análise qualitativa introduzida por Rihoux e Ragin (2009) para amostras pequenas. Nesta situação a amostra será composta por 16 países em desenvolvimento, considerados de forma estanque no ano de 2010. A segunda metodologia avalia os determinates do IED, no período de 2000 a 2010, para 75 países em desenvolvimento, por meio de análises quantitativas fundamentadas no modelo de dados em painel de efeito fixo e aleatório.

Ademais, as experiências de Moçambique e do Brasil foram analisadas em profundidade. Esses dois países apresentam ambientes institucionais bastante distintos, particularmente no que diz respeito à propriedade da terra, o que torna a análise oportuna para as discussão dos resultados obtidos nos modelos estatísticos. 
A dissertação está estruturada da seguinte forma. Após esta introdução, o capítulo 2 apresenta uma discussão da literatura sobre as abordagens NEI e TBR visando auxiliar na formulação das hipóteses sobre a problemática dos determinantes dos investimentos em terra.

O capítulo 3 corresponde à análise estatística, a qual busca integrar duas abordagens: uma qualitativa (realizada com base em comparações por expressões lógicas) e uma quantitativa (realizada com base em um modelo de dados em painel de efeito fixo e aleatório). Os resultados destas análises permitem verificar as hipóteses levantadas pela teoria e responder à pergunta de pesquisa do presente estudo - quais os determinantes do investimento externo direto em terras nos países em desenvolvimento? - de forma mais direta.

O capítulo 4 dedica-se a expor as experiências de dois países, notadamente Moçambique e Brasil, buscando investigar o ambiente institucional dos países e entender o processo de investimento externo em terras nestas localidades. A escolha por um país em cada continente (África e América do Sul) tem o intuito de verificar similaridades e dissonâncias entre as realidades institucionais dos Estados e regiões em questão.

Por fim, o capítulo 5 traz as considerações finais, bem como uma síntese dos aspectos relevantes para responder-se a pergunta de pesquisa. Serão também evidenciadas as limitações deste trabalho e sugestões para estudos futuros que venham a tratar desta temática. 


\section{A RACIONALIDADE DOS INVESTIMENTOS EM TERRAS: A NOVA ECONOMIA INSTITUCIONAL E A TEORIA BASEADA EM RECURSOS}

O objetivo deste capítulo é apresentar a abordagem teórica que irá fundamentar o principal problema de pesquisa desta dissertação, a saber: "Quais os determinantes do investimento externo direto em terras nos países em desenvolvimento?".

Para isso, parte-se da literatura da Nova Economia Institucional (NEI) que introduz a importância do ambiente institucional na análise dos incentivos aos investimentos privados (NORTH, 1990). North (1990) assume que as instituições estabelecem e alocam direitos de propriedade concomitantemente à ação do Estado, que passa a desempenhar o papel de provedor das garantias e da defesa dos direitos de propriedade.

Dessa forma, para a NEI, direitos de propriedade bem definidos e um ambiente político estável minimizam custos de transação e geram incentivos aos investimentos. No caso em particular da "terra", a titulação legal da propriedade prevalece como um dos padrões de análise mais aceitos para se determinar a definição dos direitos de propriedade; e aliada às condições de garantia de tais direitos, esta titulação determina diferentes graus de incentivos aos investimentos privados.

Ao mesmo tempo, argumenta-se que com o ambiente institucional, os investimentos em terras são guiados pela potencialidade dos recursos presentes nos países objeto das aplicações. Por esse motivo, será introduzida a Teoria Baseada em Recursos (TBR) na análise da racionalidade econômica dos agentes ao investirem em terras. Em outras palavras, verificarse-á como o potencial existente no recurso 'terra' o torna estratégico aos olhos do empreendedor, devido ao seu potencial gerador de vantagem competitiva (BARNEY, CLARK, 2007). Nota-se que quanto maiores as garantias institucionais, maior será a probabilidade de aumento da renda corrente - pela exploração e realização de valor no momento presente - e futura - dada a capacidade da terra em atuar como reserva de valor em situação de alto grau de incerteza (REYDON, 1992). 
2.1 - A Nova Economia Institucional (NEI)

A NEI surge como uma corrente teórica que busca trazer novos elementos à teoria econômica tradicional (neoclássica). Nesta última, o mercado funciona como um mecanismo precificador e os indivíduos possuem racionalidade plena, buscando maximizar seus retornos de acordo com a sua função utilidade, a qual é plenamente mensurável (ROBBINS, 1945).

Em uma situação como esta, as instituições não têm importância, pois o foco está na avaliação agregada das ações individuais, as quais geram no mercado as forças de oferta e demanda sobre determinado produto. As firmas são meramente funções de produção (também plenamente mensuráveis como às funções utilidades individuais) voltadas à geração do lucro. Segundo Kreps apud Williamson (2008):

A empresa [neoclássica] é como os agentes individuais da economia do livro-textos. (...) Os agentes têm funções de utilidade, as empresas têm uma motivação de lucro; agentes têm conjuntos de consumo, as empresas têm conjuntos de possibilidades de produção. (KREPS apud WILLIAMSON, 2008, p. 9) ${ }^{7}$.

Já na NEI, observa-se que a racionalidade não é plena (WILLIAMSON, 1985, 1991, 1996), e que os indivíduos, apesar de buscarem a maximização de seus retornos individuais, o fazem em muitas ocasiões de forma ávida e oportunista. (WILLIAMSON, 1985).

A interação entre estes agentes de racionalidade limitada pode determinar a forma que as instituições se estruturam (BROUSSEAU, RAYNAUD, 2007), e muitas vezes este formato é decorrente do poder de barganha que estes agentes têm (LIPPMAN, RUMELT, 2003). Como é justamente a estrutura das instituições presentes, onde a firma atua, que influenciará em sua forma de organização e em seu desempenho econômico (ALSTON, EGGERTSSON, NORTH, 1996; NORTH, 1990), pode-se dizer que exista um fluxo, no qual os indivíduos moldam as instituições. Estas por sua vez, determinam padrões de comportamento e conduta, que resultam em desempenho econômico às organizações (vide Figura 2).

7 "The [neoclassical] firm is like individual agents in textbook economics. (...) Agents have utility functions, firms have a profit motive; agents have consumption sets, firms have production possibility sets. (KREPS apud WILLIAMSON, 2008, p. 9) 


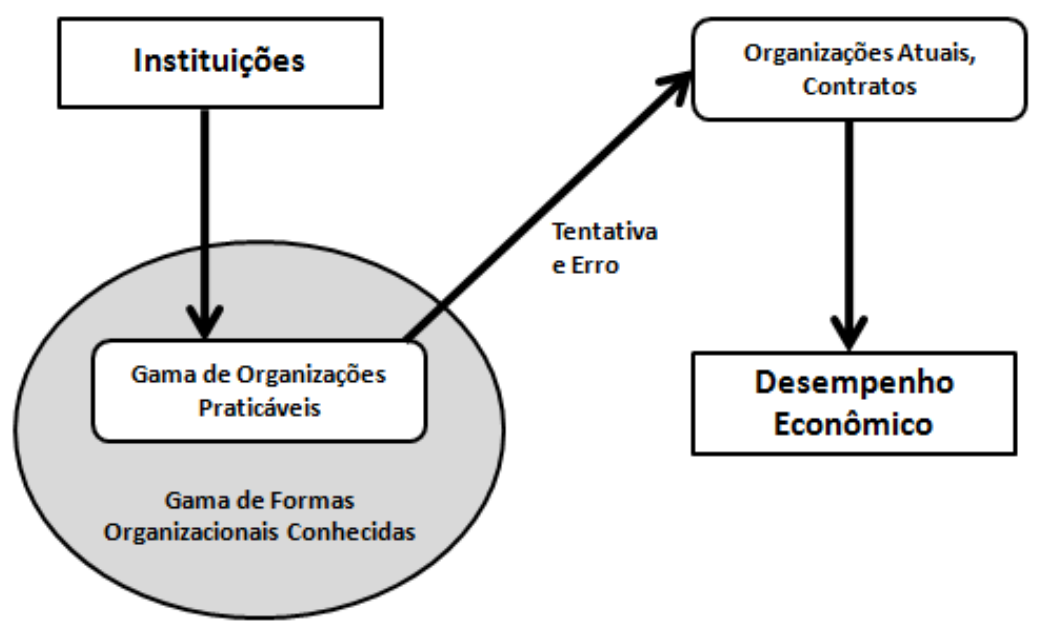

Figura 2 - Instituições e Organizações

Fonte: Alston, Eggertsson, North (1996, p.11).

Contudo, quando se aborda o tema "instituição", dificilmente consegue-se compreender o que ela é; muito menos como as instituições irão afetar o desempenho econômico das organizações. Dessa maneira, para compreender como a NEI e o estudo das instituições pode auxiliar no entendimento do recente movimento de investimentos em terras, faz-se necessário debruçar-se sobre a obra do prêmio Nobel de economia de 1993, Douglass North, a fim de compreender o que de fato são "instituições". Inicialmente North (1990) estabelece uma diferença entre "ambiente institucional" e "arranjo institucional".

O "ambiente institucional" tem um enfoque macroeconômico, pois analisa as instituições como sendo as "regras do jogo" que, presentes em um ambiente social, dão forma à interação humana, reduzindo a incerteza desta. (NORTH et al., 2009). Segundo North (1990), as mudanças institucionais e tecnológicas são determinantes para a evolução social e para o desenvolvimento econômico de uma nação. A presença de um ambiente institucional "forte" e eficiente, ao definir apropriadamente os direitos de propriedade, é fator sine qua non para o desenvolvimento econômico. Como a tecnologia está disponível, até certa medida, a todos os países, sejam eles "ricos ou pobres", são as instituições vigentes (formal ou informalmente) que determinam e retroalimentam o desempenho econômico (NORTH, 1990).

Já os "arranjos institucionais" têm um enfoque microeconômico, pois se referem aos "compromissos" realizados entre duas ou mais partes, levando em conta o regulamento 
institucional vigente no ambiente em que se inserem (NORTH, 1990). Portanto, os arranjos institucionais se debruçaram muito mais sobre a estrutura de governança que será praticada entre as partes em sua relação contratual (WILLIAMSON, 1985, 1996, 2008). É importante destacar que o presente trabalho focalizará mais o "ambiente institucional" por sua característica macroeconômica.

Conforme se observou, de acordo com North (1990), as instituições são as 'regras do jogo' presentes em um ambiente social. São elas que dão forma à interação humana e reduzem a incerteza desta. Pode-se inferir, portanto, que as instituições impactam os custos de transação existentes, já que elas definem o sistema de incentivos presentes nas ações humanas ${ }^{8}$.

É importante lembrar que, além das regras formais, o ambiente institucional é formado pelas regras informais (NORTH, 1990; AOKI, 2007). Sendo, portanto, um sistema autossuficiente de 'crenças compartilhadas' (senso comum), resultado do equilíbrio endógeno, existente após a interação em jogos repetidos, entre o conjunto de agentes presentes em uma sociedade. Entende-se por 'conjunto de agentes' tanto indivíduos físicos quanto organizações públicas e privadas.

Como as regras são embasadas pelo senso comum aos agentes, elas determinam padrões de comportamento mais estáveis, pois há uma expectativa de ação dos agentes em relação aos demais. Este fato reduz a complexidade das interações sociais, diminuindo o custo de transação presente nestas e, por consequência, transmitindo maior segurança aos indivíduos.

Entretanto, como as crenças e o senso comum mudam conforme passa o tempo, gera-se uma espécie de "equilíbrio dinâmico" na sociedade, pois há uma recorrente crise institucional e busca por novos padrões de jogos pelos agentes, o que faz emergir novas crenças, retroalimentando e reformulando os arranjos e o ambiente institucional (AOKI, 2007). Ademais, mudanças no poder de barganha fazem com que os indivíduos questionem o status quo estabelecido (LIPPMAN, RUMELT, 2003), interferindo na maneira como as instituições

\footnotetext{
${ }^{8}$ Mais especificamente, os custos de transação são: 1) oriundos dos entraves envolvidos na mensuração de atributos desejáveis, muitas vezes de difícil averiguação, e da resolução de controvérsias; 2) custos do desenvolvimento e efetivação de contratos que possibilitam a transferência dos direitos de propriedade (FURUBOTN, RICHTER, 2005, p. 48).
} 
são edificadas, muitas vezes tentando implementar formas mais vantajosas para si ou seus grupos (STIGLER, 1971).

Entretanto, um dos pontos fundamentais no entendimento dos ambientes institucionais é compreender que ele não é um bloco uníssono, mas sim uma gama de domínios articulados, sendo possível a transferência de poder de um domínio para o outro. É destacada por Aoki (2007) a concepção de que a dinâmica das instituições envolve quatro domínios principais: o domínio econômico das trocas, o organizacional, o político e o social. É por meio da interrelação destes domínios que emerge e se constituem o ambiente institucional formal e informal (vide Figura 3).

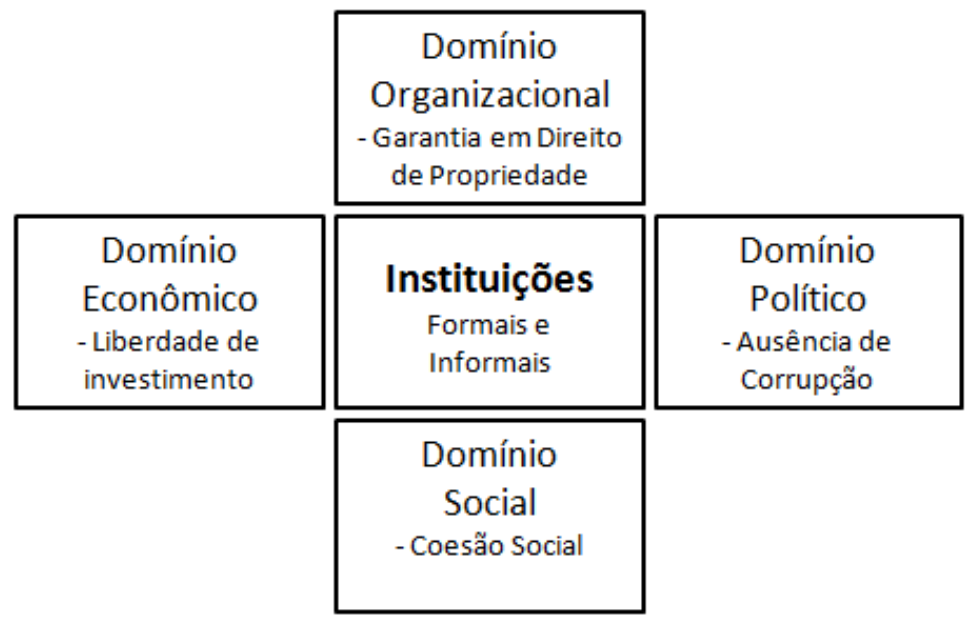

Figura 3 - Quatro pontos da dinâmica institucional segundo Aoki (2007) e possíveis relações Fonte: o próprio autor, com base em Aoki (2007)

O papel de cada um desses domínios de Aoki (2007) é determinante para a realização dos investimentos estrangeiros. Conforme se observa, os domínios - organizacional e econômico - têm um enraizamento maior nas instituições formais (como os direitos de propriedade e a liberdade de ação econômica), porque em geral estão presentes em regramentos jurídicos formalizados, como leis sobre investimentos, ou sobre uso e fruto da terra. Já os domínios político e social - estão mais ligados às instituições informais (como a coesão social, as convenções entre agentes no cumprimento dos acordos econômicos e a ausência ou tolerância para com a corrupção no domínio político). Dado que nem todos estes domínios são passíveis de uma mensuração plena e adequada, a avaliação de um ambiente institucional, ainda que possível, encontra-se sujeita a distorções. 


\subsection{1 - Hipóteses Levantadas a partir da NEI}

Conforme se observou na lógica da NEI, o ambiente institucional (formal e informal) será de importância crucial na decisão das firmas e dos investidores em realizar ou não determinado investimento em uma localidade. Tal ambiente será fundamental para garantir 'salvaguardas' (BARZEL, 1997; WILLIAMSON, 1985) aos contratos (arranjos institucionais) firmados, evitando que o investimento sofra captura de valor (BARZEL, 1997; WILLIAMSON, 1985, 1996), e tampouco que seu direito de propriedade caia em domínio público (BARZEL, 1997).

A própria literatura sobre determinantes do IED infere que as instituições são de fundamental importância para a decisão de investimento, já que estas garantem a propriedade (Ownership) dos recursos de interesse pelos agentes externos, além de estarem relacionadas com a localização (Localization) onde serão realizados os investimentos (CLEEVE, 2009; DUNNING, 2001).

Uma hipótese que se pode levantar a partir das premissas existentes na literatura da NEI é que os potenciais investidores buscam realizar aplicações em países onde o ambiente institucional assegure direitos de propriedade bem definidos (NORTH, 1990; KIM, MAHONEY, 2007). Ou seja, os investimentos serão maiores em países em que os Direitos Legais (BARZEL, 1997) estejam determinados por regras claras e com garantia de cumprimento (enforcement) do Estado, diminuindo, assim, a possibilidade de quebra de contrato oportunista (WILLIAMSON, 1985, 1996) e de perdas dos investimentos e rendas às firmas detentoras dos recursos (BARZEL, 1997; KIM, MAHONEY, 2007).

Ou seja, pode-se inferir que:

h1: Direitos de Propriedade (Força Legal) bem definidos atraem maiores volumes de IED.

Contudo, conforme se observou, não apenas os direitos de propriedade são determinantes para a avaliação de um ambiente institucional. Ao investigar o crescimento econômico no moderno 
mundo ocidental, North (1986, p. 86; 87) afirma que este "estava intimamente envolvido com o surgimento não apenas dos direitos de propriedade seguros, mas de liberdades, políticas, religiosas, e "civis". Tais liberdades envolvem: i. liberdades de expressão política e religiosa; ii. garantias contra prisão arbitrária; iii. direito à fiança; iv. proteção contra restrições aos direitos de uso, de obter renda e alienar propriedade ${ }^{10}$."

A percepção de North do vínculo entre liberdades e instituições é também compartilhada por Dahl (1997), que admite ser o regramento democrático de uma sociedade aquele que melhor garante os direitos dos cidadãos. No livro "Poliarquia" (DAHL, 1997), o autor descreve que os governos democráticos têm 'responsividade' frente a seus governados, o que os obriga a prestarem contas para seus cidadãos. Surge daí a ideia de Accountability ${ }^{11}$, que ao possibilitar a transparência das ações dos governantes, inibe a corrupção (DAHL, 1997; LIJPHART, 2003).

Porém, para que tal ordenamento democrático seja de fato vigente, são necessárias algumas condições institucionais, sendo elas: liberdade de organização, liberdade de expressão, direito de voto, fontes alternativas de informação, eleições livres e idôneas, recursos socioeconômicos dispersos, competição pública, dentre outros fatores (DAHL, 1997; LIJPHART, 2003).

Ao se observar o raciocínio de Dahl (1997) e Lijphart (2003), pode-se concluir que um ambiente institucional capaz de gerar segurança ao investidor potencial deverá se pautar por um ordenamento político "transparente", com Accountability por parte de seus governantes. Tal raciocínio se faz presente na literatura especificamente sobre IED, por exemplo, nos trabalhos empíricos de Pierpont (2007), o autor evidencia que além dos direitos de

\footnotetext{
9 "(...) was inextricably involved with the emergence not only of secure property rights but of political, religious, and 'civil' freedoms" (NORTH, 1986, p. 86; 87)

${ }^{10}$ Vale observar que as conclusões que relacionam crescimento econômico e instituições são decorrentes das pesquisas de North sobre as democracias modernas. Nas atuais democracias representativas, o autor afirma que as análises se tornam muito complexas, em função da existência de múltiplos grupos de interesse e de estrutura institucional muito mais sofisticada (NORTH, 1990: 49). De qualquer forma, a relação que está sendo abordada nessa pesquisa, não é de desempenho institucional, mas de incentivos aos investimentos, o qual se projeta uma possibilidade de obtenção de apropriação de renda futura.

${ }^{11}$ Accountability significa a "prestação de contas" (transparência) que deve existir entre o governo e os cidadãos em um ordenamento democrático.
} 
propriedade, o regramento democrático é uma variável significante para a decisão de investimento externo direto. Nas palavras do próprio autor, após uma análise sobre 54 países (dos quais 18 se encontravam na América Latina e 17 na África Subsaariana) durante o período de 1986 a 1997:

[...] este trabalho encontrou e apresentou provas de que as instituições democráticas (além de contribuírem para os direitos de propriedade) e para a proteção dos direitos de propriedade, aumentam os ingressos per capita de IED para os países em desenvolvimento. (PIERPONT, 2007, p.34) ${ }^{12}$

Pode-se, por consequência, inferir que além dos direitos de propriedade, a presença de um ambiente democrático; que garanta transparência das suas ações, com ausência ou baixo patamar de corrupção; é fundamental para a garantia do retorno dos investimentos e, por conseguinte, da decisão na aplicação de recursos. Afinal, quanto menor o nível de corrupção, maior será a certeza do investidor de que as "regras do jogo" (NORTH, 1990) não serão mudadas dependendo dos interesses particulares dos gestores públicos.

Tem-se, por conseguinte:

h2: A Ausência de Corrupção (Força Política) atrai maiores volumes de IED.

Até o momento, tem-se como hipótese duas variáveis institucionais que definem um ambiente atrativo aos investimentos externos: a existência de direitos de propriedade bem definidos e a ausência de corrupção (proxy para medir a segurança política no Estado). Não obstante, conforme visto em Aoki (2007), os domínios econômico e social também são importantes.

Outra variável institucional que, segundo a literatura, é determinante para a realização de investimento é o grau de liberdade de investimento, o qual se encontra no domínio econômico das trocas (AOKI, 2007). Desde os primeiros pensadores econômicos como Adam Smith e David Ricardo, a liberdade de investimento é um indicador de ambiente fértil para a realização de práticas econômicas. O conhecido discurso do "laissez faire, laissez aller,

$12 "(. .$.$) this paper has found and presented evidence that democratic institutions (outside of their contribution to$ property rights) and property rights protection increase per capita FDI inflows to developing countries." (PIERPONT, 2007, p.34) $)^{12}$ 
laissez passer" ("deixai fazer, deixai ir, deixai passar") indica que um ambiente econômico que permita a liberdade para atuação dos agentes conforme seus desígnios tende a ser mais produtivo, dado que cada um buscará o maior benefício possível para si, o que, segundo a corrente neoclássica, levaria a um aumento no bem social.

A inclusão de variável liberdade de investimento (representando o domínio econômico das trocas) auxilia a entender como um ambiente institucional interfere na decisão de investimento devido à força econômica do país receptor. Como condições de investimento em uma determinada localidade podem ser mais restritivas ou mais liberais, estima-se que estas últimas serão mais convidativas ao investimento externo, dado que a liberdade ao investimento diminui o risco de captura pelo Estado da renda investida. A liberdade de investimento, portanto, reduz a incerteza na obtenção dos retornos aplicados no empreendimento, bem como facilita a mobilidade dos investimentos realizados. Infere-se dessa maneira a última hipótese institucional a ser testada:

\section{h3: A Liberdade de Investimento (Força Econômica) atrai maiores volumes de IED.}

Contudo, além das três hipóteses acima formuladas, é importante compreender que estando a ordem institucional em um "equilíbrio dinâmico", a interação entre os agentes econômicos, que por sua vez depende da organização de grupos em busca do seu interesse, é determinante na forma e no padrão que este regramento será constituído (STIGLER, 1971).

A evolução da ordem institucional, de acordo com Brousseau e Raynaud (2007) ocorre a partir de um processo competitivo dinâmico. A competição entre padrões e regras que surgem por grupos de interesse articulados leva a uma corrida para a sua institucionalização, visando à proteção de diretos pelo Estado.

Por meio da repetição de jogos entre os agentes de uma sociedade, os quais detêm diferentes interesses e poderes de barganha, determinada regra é estabelecida na esfera local e voluntária. Gradualmente, conforme o jogo se realiza, as regras locais vão alcançando posições superiores nas camadas socioeconômicas (o chamado: bottom up) e assim vão se tornando genéricas e mandatárias, até sua institucionalização final. No entanto, nem sempre a regra de menor custo social é a que de fato se efetiva, mas sim aquela regra cujo grupo tem maior poder de barganha (BROUSSEAU, RAYNAUD, 2007; LIPPMAN, RUMELT, 2003), 
fazendo com que o regramento do Estado passe então a operar em "favor" deste grupo "vencedor" (BROUSSEAU, RAYNAUD, 2007; STIGLER, 1971).

Em outro trabalho, Brousseau et al (2009) evidencia que a organização legal do Estado no qual ocorre esta interação entre os agentes em busca da generalização de suas "normas particulares" pode ser efetivada sobre duas formas constitucionais distintas: a "forma liberal" e a "forma despótica" (BROUSSEAU et al., 2009, p.10). Segundo o autor, a diferença entre as duas formas decorre da assimetria de acesso às informações que os indivíduos detêm, pela distribuição desigual de direitos e pela menor possibilidade de facto de influir nas decisões políticas (ainda que esta possibilidade exista por direito) (BROUSSEAU et al., 2009).

Pode-se, assim, inferir que a forma constitucional despótica gera uma estrutura institucional mais débil, e possivelmente um Estado de opressão contra populações da base da pirâmide (PRAHALAD, 2005), o que indicaria um ambiente institucional mais frágil e potencialmente mais arriscado ao investidor externo. Assim sendo, uma ordem "despótica" seria redutor ao potencial de atração de novos investimentos. Tais fatores reforçam a pertinência das hipóteses $h 2$ e $h 3$.

De maneira contrária, a "forma liberal" possibilita um ordenamento institucional capaz de gerar estabilidade e segurança aos agentes econômicos. De qualquer forma, a dúvida que se mantém é: Como ficaria a configuração institucional em países cujos investidores externos detêm significativo poder econômico, frente a um Estado mais "debilitado"? Esta questão será abordada mais detidamente no capítulo 4 ao relatar a experiência de Moçambique.

Sumarizando, pode-se inferir que a NEI nos auxilia a identificar a importância que o ambiente institucional tem para o desenvolvimento econômico interno (NORTH, 1990), bem como para a atração de investimentos externos. (CLEEVE, 2009; DUNNING, 2001; PIERPONT, 2007). Ademais, três hipóteses foram formuladas no decorrer da análise institucional ( $h 1 ; h 2$ e $h 3)$ e estas serão tratadas em maior profundidade durante as análises qualitativa e quantitativa.

Finalmente, vale observar que as mudanças institucionais decorrem de alteração no valor econômico dos recursos. Portanto, com o aumento do valor destes, os proprietários passam a ter incentivos para demandar maior definição dos direitos de propriedade visando capturar as 
rendas dos investimentos realizados. Ou seja, quanto melhor definido os direitos de propriedade maior será o valor do recurso e vice-versa.

\section{2 - A Teoria Baseada em Recursos (TBR)}

Conforme se observou na seção anterior, o ambiente institucional define condições para atratividade dos investimentos privados. No entanto, os investimentos em terras são guiados também pelas potencialidades dos recursos presentes nos países-alvo das aplicações. Dunning (2001), baseando-se na lógica da Propriedade, Localização e Internacionalização (Ownership, Localization and Internationalization), argumenta que os movimentos de investimento externo direto (IED), de uma forma geral, dependem dos recursos, ou nas palavras do autor, de ativos estratégicos existentes na localidade.

$\mathrm{O}$ autor ressalta que muitas vezes a internacionalização de uma empresa ocorre pelos incentivos à coordenação de um recurso existente em outra região. Ou seja, quanto maior o: "[...] mecanismo para coordenar o uso de recursos, maior será o incentivo para as empresas a realizarem IED." (DUNNING, 2001, p.177). ${ }^{13}$ Justamente pelos atributos que alguns recursos têm na geração de rendas à firma, raciocínio este, semelhante à da TBR. A fim de melhor controlar recursos estratégicos, a internacionalização passa ser a melhor forma de proceder para a firma obter vantagens competitivas (VC).

A TBR é, portanto, capaz de fundamentar a análise dos determinantes dos investimentos em terra, ao se debruçar sobre sua questão fundamental, que é entender: 'como as firmas adquirem e sustentam vantagens competitivas, permitindo superar suas concorrentes?". ${ }^{14} \mathrm{Ou}$ em outras palavras, 'por que algumas firmas superam as outras?'

13 "(...) mechanism for coordinating resource usage, the greater will be the incentive for firms to engage in FDI." (DUNNING, 2001, p.177).

${ }^{14}$ Conforme se observou na introdução, a TBR que foi inicialmente proposta por Penrose (1959) e desenvolvida por Peteraff (1993), Barney e Clark (2007), dentre outros, surge na década de 1990 com uma proposição inovadora sobre o porquê de a firma existir. 
Para responder essa questão, a TBR admite que a firma seja constituída por um conjunto de recursos e capacidades que são organizadas internamente segundo suas rotinas e processos de aprendizagens (WERNERFELT, 1984, 1995; BARNEY, 1991; PETERAF, 1993). O que, de acordo com sua capacidade de acesso a recursos estratégicos no mercado de fatores e competência de organizá-los internamente; permite à firma adquirir Vantagens Competitivas Sustentáveis (VCS) sobre suas concorrentes.

A lógica desse argumento baseia-se na teoria de David Ricardo ${ }^{15}$, economista inglês do século dezenove, que destacou a importância de um recurso, no caso a terra, como mecanismo determinador da renda em uma sociedade e como mecanismo potencial de obtenção de lucro ${ }^{16}$.

Segundo a 'teoria da renda da terra' de David Ricardo, a terra existe em quantidade limitada e tem níveis diferentes de fertilidade e, portanto, produtividades diferentes. Adicionalmente, à medida que a população e a demanda crescem, tem início a utilização de terras de qualidade inferior.

Assim, é preciso pagar uma renda pelo uso da terra de melhor qualidade, sendo esta renda determinada pela diferença de produtividade entre as terras de "primeira" e "segunda ordem". Esta relação é crescente, ou seja, à medida que a população e a demanda expandem, utilizamse as terras marginais (de qualidade inferior). São exatamente estas terras marginais que determinarão a renda paga aos proprietários das terras de "primeira ordem", devido à diferença no nível de produtividade obtida. Nas palavras do próprio Ricardo (1996): "Concluímos, portanto, que é sempre a mina menos produtiva que regula o preço do carvão" (RICARDO, 1996, p.240).

\footnotetext{
${ }^{15}$ Economista inglês (1772-1823) que em "Princípios de Economia Política e Tributação", publicado em 1817, se debruça sobre diversas questões importantes à economia da época, a qual estava em um momento de transição do mercantilismo para o capitalismo.

${ }^{16}$ Vale dizer que a retomada do conceito de rendas ricardianas tem o intuito de melhor explicar o conceito de rendas superiores e vantagens competitivas sustentáveis, e não inferir que terras dos países em desenvolvimento seriam mais ou menos produtivas que as existentes nos países desenvolvidos. Em outras palavras, o argumento ricardiano é aqui colocado com finalidade teórica para melhor explicar o conceito de Vantagens Competitivas Sustentáveis.
} 
Dessa afirmação deduz-se o conceito de rendas ricardianas e, por consequência, de vantagens competitivas, uma vez que:

Suponhamos que todas as terras proporcionassem renda. Nesse caso, o montante da renda da terra de pior qualidade seria proporcional ao valor da produção que excedesse as despesas de capital e lucro corrente do capital. (RICARDO, 1996, p.240)

Ou seja, as terras de pior qualidade utilizadas na produção têm como produto líquido o "lucro" que remunera o capitalista e os "salários" que remuneram os trabalhadores, porém não existe aqui uma "renda excedente", já que não existe diferencial nesta terra frente a outras utilizadas na produção (vide Figura 4).

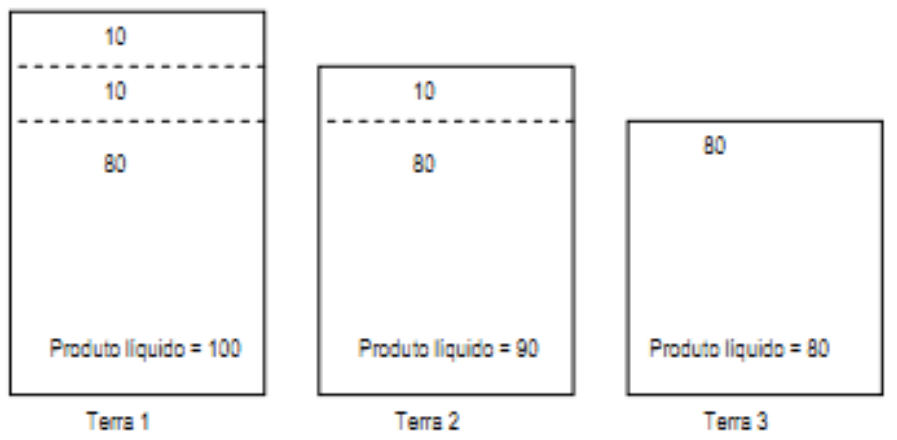

Figura 4 - Renda da terra segundo Ricardo Fonte: Hunt (2005, p.89)

A terra de melhor qualidade, além de remunerar os trabalhadores ('despesas de capital') e os capitalistas ('lucro corrente do capital'), gera uma 'remuneração extra', equivalente ao diferencial que proporciona frente à terra de pior qualidade (terra marginal).

A renda é determinada pelo mesmo princípio, quer se cultive trigo ou batatas: será igual à diferença entre a produção obtida com igual montante de capital em terras de mesma qualidade ou não e, portanto, enquanto forem cultivadas terras da mesma qualidade ou enquanto não se alterar sua fertilidade ou suas vantagens relativas, a renda será sempre proporcional à produção bruta. (RICARDO, 1996, p.242)

Este diferencial, (renda ricardiana), obtido pela produção na terra de melhor qualidade frente à realizada na terra marginal, constitui a 'vantagem relativa' (geração de renda superior) que a terra de primeira ordem proporciona àqueles que detêm este recurso sob sua posse.

A lógica das rendas ricardianas foi retomada nos anos 1990 pelos economistas da Teoria Baseada em Recursos (TBR), que admitem que as principais fontes das diferenças de 
rentabilidade entre as firmas decorrem da posse de recursos capazes de gerarem rendas no sentido ricardiano, isto é, de retorno superior ao custo de oportunidade. Posto de outra forma, assume-se que rendas econômicas derivam não apenas de estruturas de mercado monopolísticas, mas também de insumos valiosos e escassos decorrentes de imperfeições do mercado de fatores (PETERAF, 1993).

Estas imperfeições surgem da habilidade gerencial, da linguagem singular utilizada no interior da firma e de sua cultura organizacional idiossincrática. Decorrem também de ativos físicos e inovações, protegidas por patentes ou por competência organizacional, e ainda de ativos intangíveis tais como: confiança do consumidor, imagem da marca, capital reputacional, contratos relacionais, dentre outras possibilidades. Tais fatores de produção são perfeitamente inelásticos, já que suas quantidades ofertadas são fixas (são únicos) e não respondem a mudanças nos preços (WERNERFELT, 1984; 1995; BARNEY, 1991; PETERAF, 1993, BARNEY, CLARK, 2007).

A relação entre os recursos estratégicos, as vantagens competitivas e as rendas ricardianas pode ser entendida por meio do esquema criado por Barney e Clark (2007), apresentado na Figura 5.

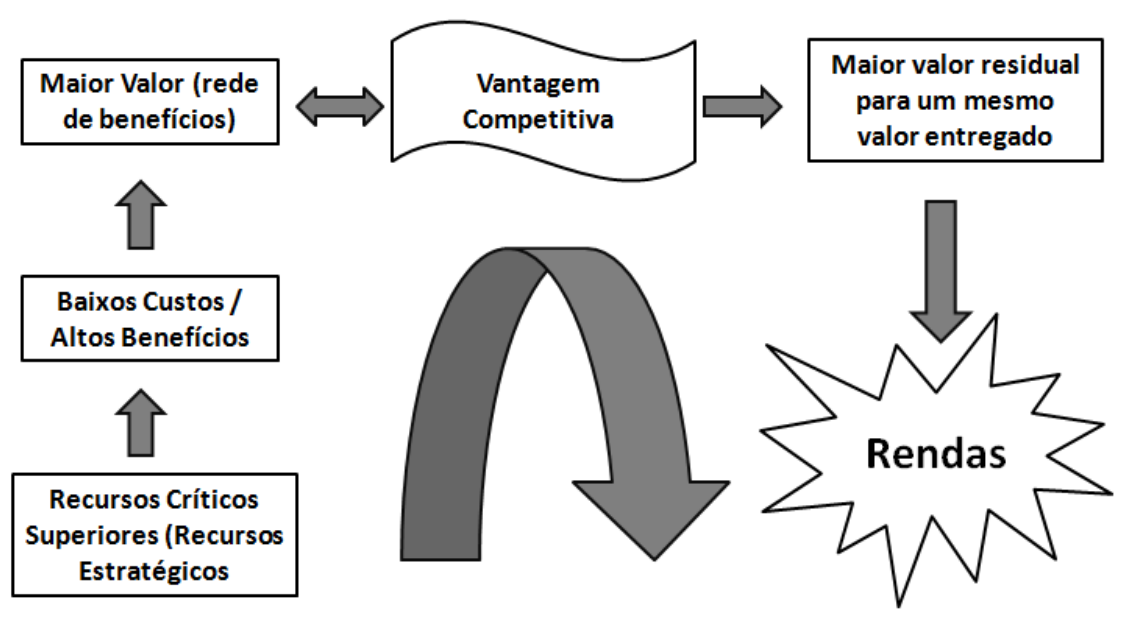

Figura 5 - Fluxo dos recursos à renda Fonte: Barney e Clark (2007, p.28).

Segundo Barney e Clark (2007), é possível entender uma performance persistentemente superior atentando-se aos recursos controlados pela firma (BARNEY, CLARK, 2007). Quanto mais estratégico for um recurso (recurso crítico superior) e quanto maiores forem as 
barreiras de isolamento frente aos concorrentes, maior ser a tendência de a firma obter VCS e, por conseguinte, rendas ricardianas.

Observa-se que nesta abordagem o estrategista tem um papel fundamental, pois mesmo quando os recursos são oriundos de mercados competitivos, é o estrategista quem julga seu potencial de geração de valor (BARNEY, CLARK, 2007). Seja por diferenças na avaliação da probabilidade de lucros futuros (FOSS, et al., 2007), seja por valorar diferentemente os atributos (BARZEL, 1997), ou mesmo por sorte (BARNEY, CLARK, 2007). Assim sendo, devido à complexidade informacional e incerteza, os agentes, ao realizarem julgamentos distintos (FOSS et al, 2007), podem auferir rendas diferenciais, mesmo que estejam atuando em mercados considerados perfeitamente competitivos.

Segundo Barney e Clark (2007), o sucesso de uma estratégia de obtenção de rendas ricardianas depende de algumas peculiaridades presentes nos recursos pertencentes à firma. Tais peculiaridades são denominadas de VRIO (Value, Rare, Imperfectly Imitable and Organization), no qual:

Valioso - o recurso deve ter um valor intrínseco que faça com que os consumidores enxerguem um benefício superior nos produtos oriundos deste recurso (maximizing de benefícios), ou que faça a firma economizar em custos de produção pela sua utilização (minimizing em custos).

Um recurso valioso habilita a empresa a aumentar o valor econômico que ela cria, aumentando a disposição dos clientes a pagar, diminuindo seus custos, ou ambos. (BARNEY, CLARK, 2007, p.58) ${ }^{17}$.

Raro - o recurso deve ser relativamente escasso, ou seja, não está disponível para ser utilizado por um grande número de firmas nos moldes de um mercado de concorrência perfeita.

Se um recurso valioso particular de determinada empresa é possuído por um grande número de firmas, então cada uma dessas firmas tem a capacidade de explorar esse

\footnotetext{
17 " A valuable resource enables a firm to increase the economic value it creates by increasing the willingness of customers to pay, decreasing its costs, or both." (BARNEY, CLARK, 2007, p.58).
} 
recurso da mesma maneira, implementando assim uma estratégia comum que não dá a nenhuma das firmas vantagem competitiva. (BARNEY, CLARK, 2007, p.58) ${ }^{18}$.

Imperfeitamente Imitável ou Substituível - o recurso não deve ser passível de imitação, duplicação ou substituição, caso contrário, empresas concorrentes facilmente o replicariam, perdendo sua essência de recurso estratégico, devido o retorno ao mercado de concorrência perfeita.

No entanto, valiosos e raros, recursos organizacionais só podem ser fontes de vantagem competitiva sustentável se as firmas que não possuem esses recursos não puderem obtê-los por duplicação direta ou substituição. (BARNEY, CLARK, 2007, p.59) $)^{19}$.

Organização - a empresa detentora do recurso valioso, raro e não imitável/substituível, só consegue obter vantagens competitivas ao conseguir se organizar internamente, ou por meio de inter-relações em redes (DYER, SINGH, 1998), de forma a explorar positivamente o referido recurso estratégico. "Processos organizacionais fornecem a quarta condição necessária para a realização de vantagem competitiva sustentável." (BARNEY, CLARK, 2007$, p.67 $)^{20}$.

Por fim, vale ressaltar que para satisfazerem-se às condições expostas, é necessário pressupor a existência de imperfeições no mercado de fatores, o que não é considerado na abordagem neoclássica. Possivelmente, este venha a ser outro motivo que impulsiona as firmas a investirem nos países em desenvolvimento, já que nestas localidades, pela imperfeição dos mercados, cria-se um potencial ainda inexplorado de geração de VCS (DUNNING, 2001).

\footnotetext{
18 "If a particular valuable firm resource is possessed by large numbers of firms, then each of these firms has the capability of exploiting that resource in the same way, thereby implementing a common strategy that gives no one firm a competitive advantage." (BARNEY, CLARK, 2007, p.58).

19 "However, valuable and rare organizational resources can only be sources of sustained competitive advantage if firms that do not possess these resources cannot obtain them by direct duplication or substitution." (BARNEY, CLARK, 2007, p.59)

20 "Organizational processes provide the fourth condition necessary for realization of sustainable competitive advantage." (BARNEY, CLARK, 2007, p.67)
} 


\subsection{1 - A Terra Como Recurso Estratégico}

Historicamente, a terra é vista como um recurso estratégico. Conforme se observou, a TBR tem suas raízes na teoria ricardiana, a qual já considerava a terra como geradora de rendas superiores a seus detentores, em função das diferenças de produtividade desse recurso. Contudo, não é apenas pelos atributos produtivos que a terra é um recurso estratégico, mas também pelo seu potencial de liquidez. Já que esta se constitui em uma fonte segura ao investidor em momentos de incerteza, particularmente pela possibilidade de manutenção de valor no longo prazo (REYDON, 1992).

Dessa forma, como o futuro é incerto, e a capacidade cognitiva do ser humano o impede de vislumbrar possíveis crises futuras, os ativos mais líquidos tendem a ser mais valorizados pela sua alta capacidade de realização no mercado spot e reconversão em moeda. Sendo assim:

[...] pode-se classificar a terra como sendo um ativo líquido, que pode ser adquirida para garantir um ganho final de algum período com sua revenda, além de eventualmente gerar fluxos de renda durante sua vida útil. (REYDON, 1992, p.94)

Tal liquidez por si já poderia ser considerada como um fator determinante para os investimentos em terra. No entanto, a liquidez, somada à sua capacidade de gerar renda ao longo do tempo, possibilita classificá-la como um "ativo especial" (REYDON, 1992, p.94).

É justamente neste ponto relativo à geração de renda durante a vida útil da terra que se encontra a relação entre o ativo "terra" com a TBR. Esta capacidade de geração de renda é um importante fator que condiciona o investidor na definição de quais atributos físicos devem ser valorizados na decisão de aquisição. Essa decisão depende da perspectiva que o investidor tem sobre os retornos futuros, que naturalmente condicionaram a valorização da terra como ativo financeiro. Isso é particularmente verdadeiro quando se consideram as perspectivas de aumento das commodities agrícolas observadas no capítulo 1.

Dessa forma, antes de definirem suas estratégias de aquisição de recursos estratégicos, no caso a terra, os investidores atentam para o valor que estes terão no futuro, conforme nos afirmam Barney e Clark (2007): 
Em resumo, firmas que procuram obter vantagens competitivas pela implementação de estratégias no mercado de produtos devem ter expectativas consistentemente mais apuradas sobre o valor futuro dessas estratégias, ao desenvolver ou adquirir os recursos necessários para implementá-las, ou em outro caso as empresas podem contar com a sorte. (BARNEY, CLARK, 2007, p.46) $)^{21}$

Dessa forma, ao vislumbrar a importância dos recursos para a geração de VC tanto no presente quanto no futuro, serão a seguir apresentados, sob a luz da TBR, os atributos considerados na decisão de investir no recurso terra, visando obter VCS. Serão também discutidas as hipóteses do modelo com base na TBR, a serem testadas no capítulo 3 .

\subsection{2 - Hipóteses Levantadas pela TBR}

Como se observou anteriormente, os recursos possuem quatro elementos que definem as VCS: Valor, Raridade, Não Imitação e Organização. A fim de se verificar como os recursos estratégicos definidos pela TBR impactam no nível de IED, as variáveis - Valor e Raridade serão mensuradas conjuntamente considerando a proxy Disponibilidade de Terras Agricultáveis, que possibilita a formulação da quarta hipótese de pesquisa:

h4: A maior Disponibilidade de Terras Agricultáveis atrai maiores volumes de IED.

Estima-se que quanto maior a disponibilidade de terras agricultáveis, maior o volume de investimentos a serem atraídos, justamente pela maior existência do recurso valioso e raro na localidade.

O impacto da Não Imitação e da Organização será mensurada pela proxy Produtividade da Terra existente nos países em desenvolvimento. A proxy tem como justificativa o fato de que o baixo rendimento de uma terra de qualidade superior (não é imitável, nem replicável)

\footnotetext{
21 "In Summary, firms seeking to obtain competitive advantages from implementing product market strategies must have consistently more accurate expectations about the future value of those strategies when developing or acquiring the resources necessary to implement them, although firms can be lucky." (BARNEY, CLARK, 2007, p.46)
} 
ocorreria devido ao uso ineficiente deste recurso estratégico. Admite-se, que esta ineficiência é decorrente, dentre outros fatores, da debilidade organizacional da produção realizada nos países em desenvolvimento (frente à produção intensiva dos desenvolvidos), fator que implica a exploração inadequada do recurso. Consequentemente, será utilizada a proxie Produtividade da Terra (tons/ha) como a quinta hipótese do modelo.

h5: Quanto menor for a Produtividade da Terra (rendimento), maior é o potencial de atração de IED.

Estima-se, portanto, que quanto menor a produtividade, maior será o nível de IED, pois os investidores estariam interessados em explorar a brecha de produtividade existente no recurso estratégico subutilizado.

\section{3 - Importância da Interação entre NEI e TBR}

As hipóteses oriundas da TBR, aliadas às construídas a partir da NEI, possibilitam lidar com a principal crítica que se faz à TBR na atualidade (FOSS, FOSS, 2005; KIM, MAHONEY, 2007), qual seja, considerar que os direitos de propriedade dos recursos estão assegurados e, portanto, as rendas criadas serão plenamente apropriadas.

Segundo Foss e Foss (2005) e Kim e Mahoney (2007), a TBR toma como dado e como perfeitamente delimitado, o direito de propriedade das firmas sobre os recursos por elas detidos e explorados. Assim sendo, toda a renda potencial dos recursos, ao ser criada, é transformada em renda realizada pela firma detentora dos referidos recursos.

Contudo, no 'mundo dos negócios', no qual os direitos de propriedade não são plenamente clarividentes, seja pela dificuldade em valorar todos os atributos dos recursos (BARZEL, 1997), seja pela dificuldade de formular contratos completos (WILLIAMSON, 1985; 1996), as rendas criadas nem sempre são completamente apropriadas por seus residual claiments. Nas palavras de Kim e Mahoney (2007): 
Em contextos de negócios, onde há uma luta por direitos de propriedade, no entanto, não podemos mais assumir com segurança que a empresa necessariamente captura a rendas econômicas. (KIM; MAHONEY, 2007, p.12) ${ }^{22}$.

Infere-se, portanto, que no ambiente de negócios do 'mundo real', ainda que a firma detenha a posse de um recurso estratégico potencialmente gerador de renda, esta renda gerada pode não ser diretamente realizada (apropriada) pela firma, podendo ser dissipada ou usurpada; dependendo do tipo de direito de propriedade que exista no ambiente institucional em que a firma opera.

A firma pode falhar em obter rendas econômicas, uma vez que o potencial para criação de valor ex ante não garante a real apropriação de valor ex post; sendo assim, os direitos de propriedade são fundamentais para a geração de rendas ricardianas a partir das VCS advindas dos recursos. Ou seja, a obtenção de VCS depende não apenas da criação de valor por meio da utilização de recursos escassos e de difícil imitação, mas também dos custos de controlar os direitos de propriedade desses recursos (FOSS, FOSS, 2005).

Dado que, de acordo com Coase apud Kim; Mahoney (2007):

[...] a partir da perspectiva dos direitos de propriedade, os recursos que uma empresa possui não são os recursos físicos, mas sim são feixes de direitos de propriedade. (COASE, 1960 apud KIM, MAHONEY, 2007, p.14) ${ }^{23}$.

Ao considerar as firmas como "feixes de direitos de propriedade" sobre os recursos, Kim e Mahoney (2007) estão basicamente estabelecendo que as firmas são organizações dependentes do ambiente institucional em que se inserem, pois é este ambiente que determinam 'as regras do jogo' a que as firmas estão sujeitas (NORTH, 1990).

A partir dessa discussão, pode-se construir um modelo composto pelas cinco hipóteses acerca da dinâmica dos investimentos em terras, baseado nas abordagens da NEI e TBR, conforme se observa na Figura 6.

\footnotetext{
22 "In business contexts where there is a struggle for property rights, however, we can no longer safely assume that the firm necessarily captures the economic rents.".

${ }^{23}$ "[...] from the property rights perspective, resources that a firm 'owns' are not the physical resources but rather are bundles of property rights" (COASE, 1960).
} 


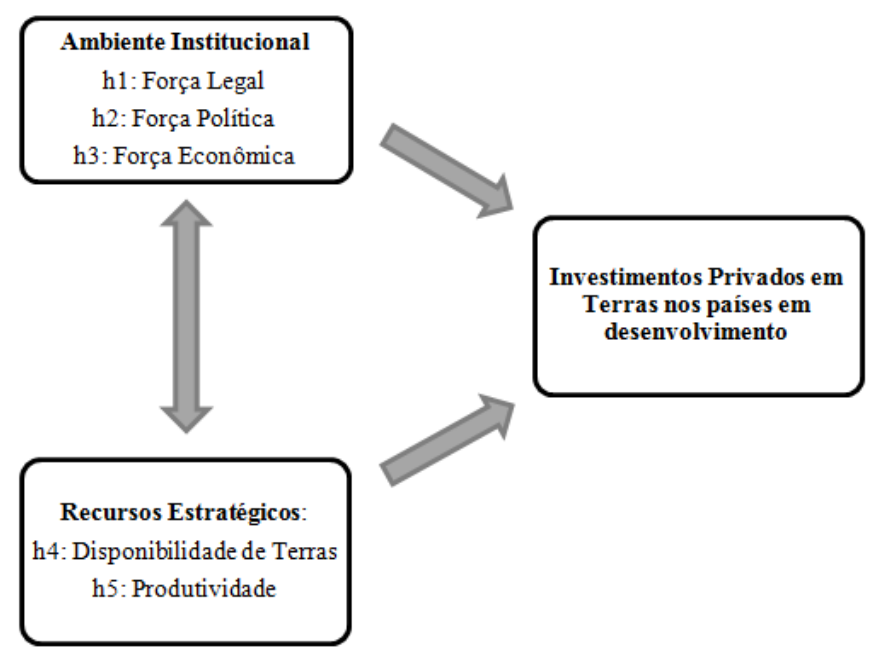

Figura 6 - Dinâmica e Hipóteses para o IED em Terras Fonte: o próprio autor.

Adiante será explicitada a metodologia a ser utilizada para testar as cinco hipóteses levantadas pela teoria. 


\section{ANÁLISE APLICADA SOBRE OS DETERMINANTES DO INVESTIMENTO EXTERNO DIRETO NOS PAÍSES EM DESENVOLVIMENTO}

A metodologia realizada no presente trabalho visa identificar os determinantes do investimento externo direto nos países em desenvolvimento, sobretudo aqueles que vêm sendo objetos de aplicações em terras agricultáveis. Deu-se destaque fundamental aos países da América do Sul, Central e Caribe, bem como à África Subsaariana.

Para a identificação dos determinantes do investimento, foram realizadas dois tipos de análises estatísticas: uma qualitativa comparativa e outra quantitativa. Estas análises, de forma combinada, permitirão identificar os fatores determinantes do investimento em terras, bem como, relacionar estes fatores com as hipóteses levantadas. Será possível, portanto, apresentar uma análise da dinâmica do movimento de "extrangeirização agrícola" (MUJCA DIJO QUE EN SU GOBIERNO NO SE VENDERÁN TIERRAS A OTROS PAÍSES, 2010).

3.1 - Análise Estatística Qualitativa e os determinantes do IED

A análise estatística qualitativa baseia-se na metodologia desenvolvida por Rihoux e Ragin (2009) no livro: Configurational comparative methods. Qualitative Comparative Analysis (QCA) and related techniques. Segundo os autores, é possível, por meio de softwares específicos para análise comparativa em pequenas amostras, definir-se expressões lógicas capazes de explicar quais são as condições necessárias e suficientes para obter um determinado resultado.

O modelo de Rihoux e Ragin (2009) destaca casos com comportamentos semelhantes, mas que apresentam resultados diferentes ou vice-versa (vide Figura 7). Nesse sentido, o modelo é capaz de mostrar os determinantes lógicos para a ocorrência de um resultado que se pretende explicar. 


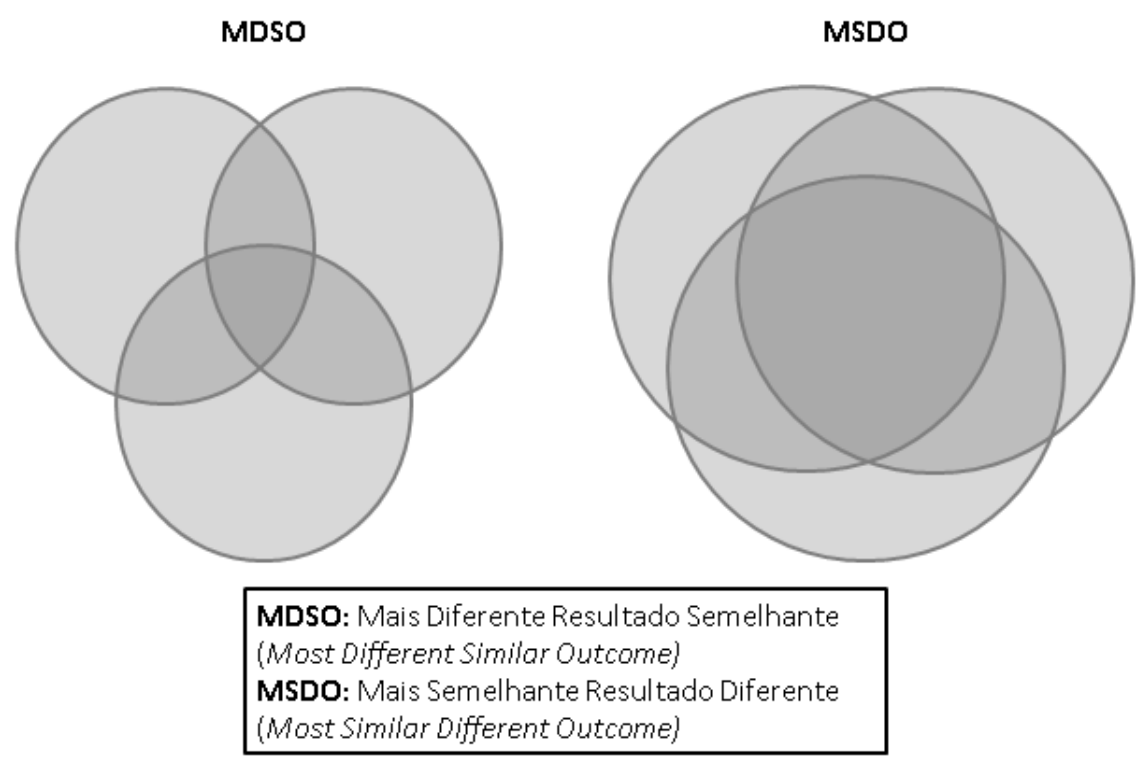

Figura 7 - Desenho dos sistemas: mais semelhantes e mais diferentes Fonte: Rihoux; Ragin (2009, p.23)

Segundo os autores, esta metodologia é especialmente desenvolvida nas ciências sociais com amostras pequenas (n maior que cinco e menor que 30) e tem sido usada amplamente nas pesquisas em ciência política; como por exemplo, no livro "Political Man" (LIPSET, 1960), no qual Lipset busca comparar grupos diferentes de países, a fim de inferir os condicionantes sociais que determinam um ordenamento democrático como resultado.

Portanto, seguindo a linha de Lipset (1960) e de Rihoux e Ragin (2009), este trabalho objetiva fazer uso da metodologia de análise comparativa qualitativa crip-set (a ser explicada mais detalhadamente no Anexo 1) com a finalidade de verificar dentre variáveis (institucionais e de recursos) quais são os determinantes necessário e/ou suficientes para explicar um relativo alto valor de IED nos países selecionados.

Para realizar o teste foi utilizado o software TOSMANA (CRONQVIST, 2003, 2007), o qual consiste de uma ferramenta para análise de n pequeno (Tool for SMAll $N$ Analysis). A fim de explicitar didaticamente a metodologia utilizada, o Anexo 1 apresenta a sequência das passos adotados segundo Rihoux e Ragin (2009) de forma mais detida. 


\subsection{1 - Variáveis da Análise Qualitativa}

Conforme já explicitado, a análise qualitativa tem como finalidade verificar a importância das variáveis 'recursos estratégicos' e das variáveis institucionais como determinantes do IED. Vale destacar que a escolha pela análise qualitativa comparativa deriva do fato de essa metodologia permitir a observação de cada caso, de forma a considerar as idiosincrasias de cada um dos países selecionados.

Foram, portanto, analisados 16 países, a saber: África do Sul (ZAF), Angola (AGO), Argentina (ARG), Bolívia (BOL), Brasil (BRA), Burkina Faso (BFA), Chad (TCD), Etiópia (ETH), Madagascar (MDG), México (MEX), Moçambique (MOZ), Paraguai (PRY), República Centro Africana (CAF), Uruguai (URY), Venezuela (VEN) e Zâmbia (ZMB) ${ }^{24}$. Vale reforçar que a análise foi realizada apenas para o período de 2010, com o intuito de terse uma visualização estanque dos resultados do modelo csQCA.

Antes de proceder com a descrição das variáveis, deve-se observar que uma limitação na escolha das proxies é a impossibilidade de obter informações de IED em terras. Dessa forma, foi escolhido o IED agregado que, apesar de restringir a capacidade explicativa de ambos os modelos, dado o foco nos países em desenvolvimento permite inferir que esta se trata de uma proxy adequada devido à importância do setor primário destas nações. Para se ter dimensão, grande parte dos investimentos diretos nos países africano é no setor primário, sendo que em alguns deles, como no caso de Moçambique por exemplo, o referido setor recebeu $85 \%$ de todo investimento externo direto no ano de 2009 (CPI, 2009).

Feita a presente ressalva, à aplicação da técnica csQCA requer a dicotomização das variáveis por meio da definição de 'pontos de inflexão'/'limiares' que segregem os casos segundo a presença ou ausência de determinado fator. Segundo Rihoux e Ragin (2009), a definição clara e transparente dos pontos de inflexão é fundamental para a robustez dos resultados. Abaixo

\footnotetext{
${ }^{24}$ Vale destacar que a escolha destes 16 países se deu por de forma não probabilística, mas por conveniência. Os países foram escolhidos, pois no relatório do Banco Mundial (2010), havia dados de produtividade de milho para todos. Sendo esta cultura comum a todos estes países, permitiu se isolar possíveis condições idiossincráticas de cada país no que se refere à produtividade.
} 
são apresentadas as variáveis do modelo, bem como a forma pela qual elas foram dicotomizadas, para fins de análise qualitativa.

\section{- IED per Capita}

A variável explicativa do modelo (IED per capita) foi dicotomizada por meio da definição do ponto de inflexão no ponto mediano entre os valores de IED recebido por cada um dos 16 países. Ou seja, o limiar da variável IED é o ponto que divide a metade inferior (oito países com menor IED per capita) da metade superior (os demais oito países com maior IED per capita).

Já as variáveis independentes (variáveis Institucionais e de Recursos) buscaram seguir as hipóteses apresentadas no capítulo 2. A categoria Institucional é composta por três variáveis, todas obtidas no banco de dados The Wall Street Journal - Heritage Foundation. A própria Heritage traz um valor para cada variável seguindo uma gradação de 0 a 100 , variando do pior para o melhor resultado em cada um dos indicadores, facilitando assim a dicotomização das variáveis. Abaixo, seguem as discrições detalhadas das variávies:

\section{- Força legal/Direitos de Propriedade:}

O componente de direitos de propriedade é uma avaliação da capacidade dos indivíduos para acumular a propriedade privada, garantidos por leis claras que são plenamente aplicados pelo Estado. Ele mede o grau em que as leis de um país protegem os direitos de propriedade privada e o grau em que seu governo aplica essas leis. (HERITAGE FOUNDATION, 2011b) ${ }^{25}$

A Figura 8 apresenta um mapa construído pela Heritage Foundation com os valores do indicador Direitos de Propriedades segundo cada país classificado. As cores quentes indicam países com direitos de propriedade mais fragilmente assegurados pelo Estado, frente aos mais seguros, representados com cores mais frias.

\footnotetext{
25 "The property rights component is an assessment of the ability of individuals to accumulate private property, secured by clear laws that are fully enforced by the state. It measures the degree to which a country's laws protect private property rights and the degree to which its government enforces those laws." (HERITAGE FOUNDATION, 2011b)
} 


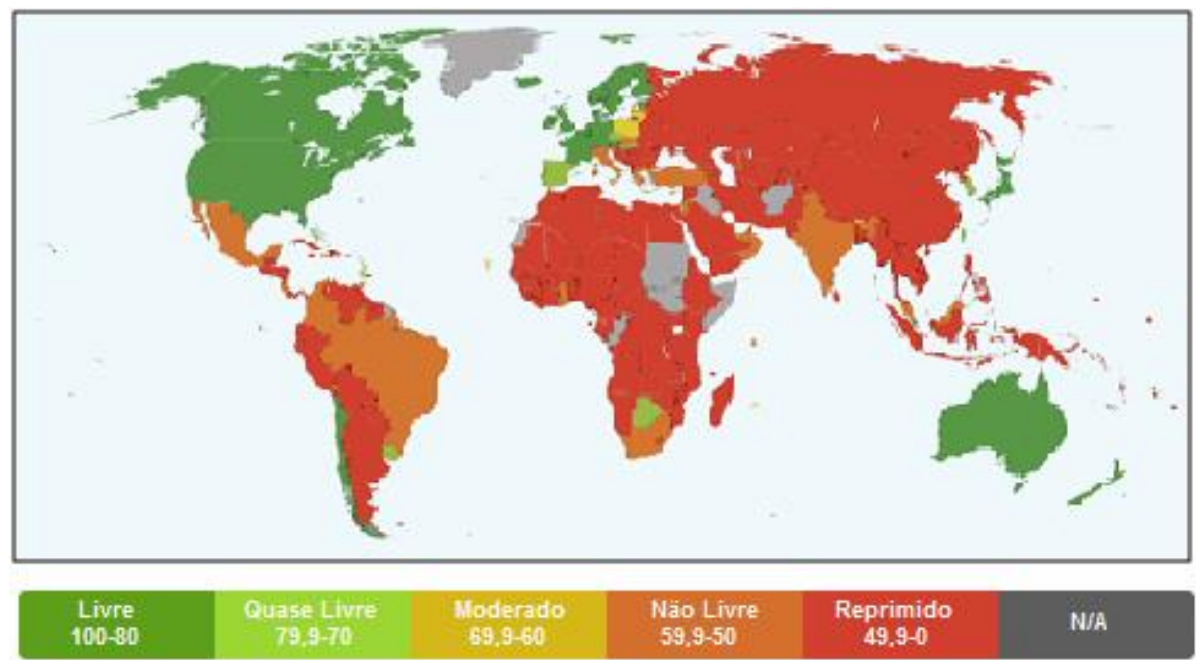

Figura 8 - Classificação dos países segundo indicador de Direitos de Propriedade Fonte: Heritage Foundation (2011b).

\section{- Força Política/Ausência de Corrupção:}

"A corrupção corrói a liberdade econômica pela introdução de insegurança e incerteza nas relações econômicas." (HERITAGE FOUNDATION, 2011c) ${ }^{26}$. Também a Figura 9 apresenta um mapa construído pela Heritage Foundation sobre o indicador Ausência de Corrupção. Nesse gráfico, de forma semelhante, as cores quentes revelam onde a corrupção está mais presente e as cores frias onde ela está mais ausente.

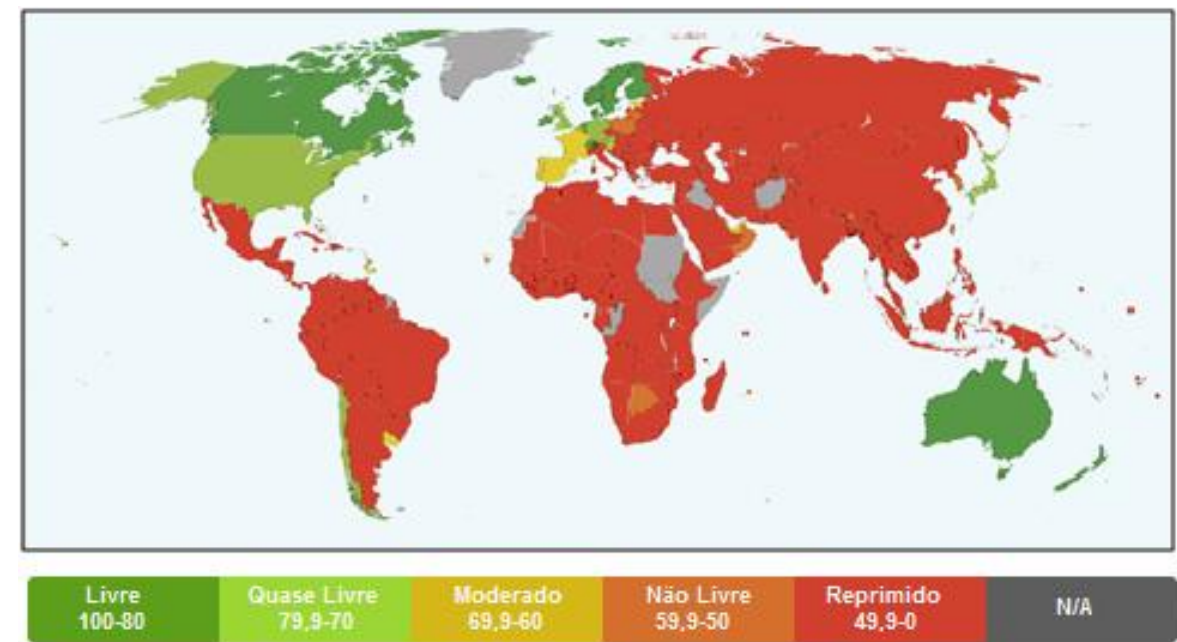

Figura 9 - Classificação dos países segundo indicador de Ausência de Corrupção Fonte: Heritage Foundation (2011c). 


\section{- Liberdade de Investimento:}

Em um país economicamente livre, não haveria restrições sobre o fluxo de capital de investimento. Os indivíduos e as empresas seriam autorizados a movimentar seus recursos dentro e fora de atividades específicas, tanto internamente quanto através das fronteiras do país, sem restrições. (HERITAGE FOUNDATION, 2011a). ${ }^{27}$

A Figura 10 apresenta um mapa construído pela Heritage Foundation com os valores da variável Liberdade de Investimento. As cores quentes indicam países mais restritivos aos investimentos, frente aos mais liberais destacados pelas cores mais frias, conforme mostra a legenda.

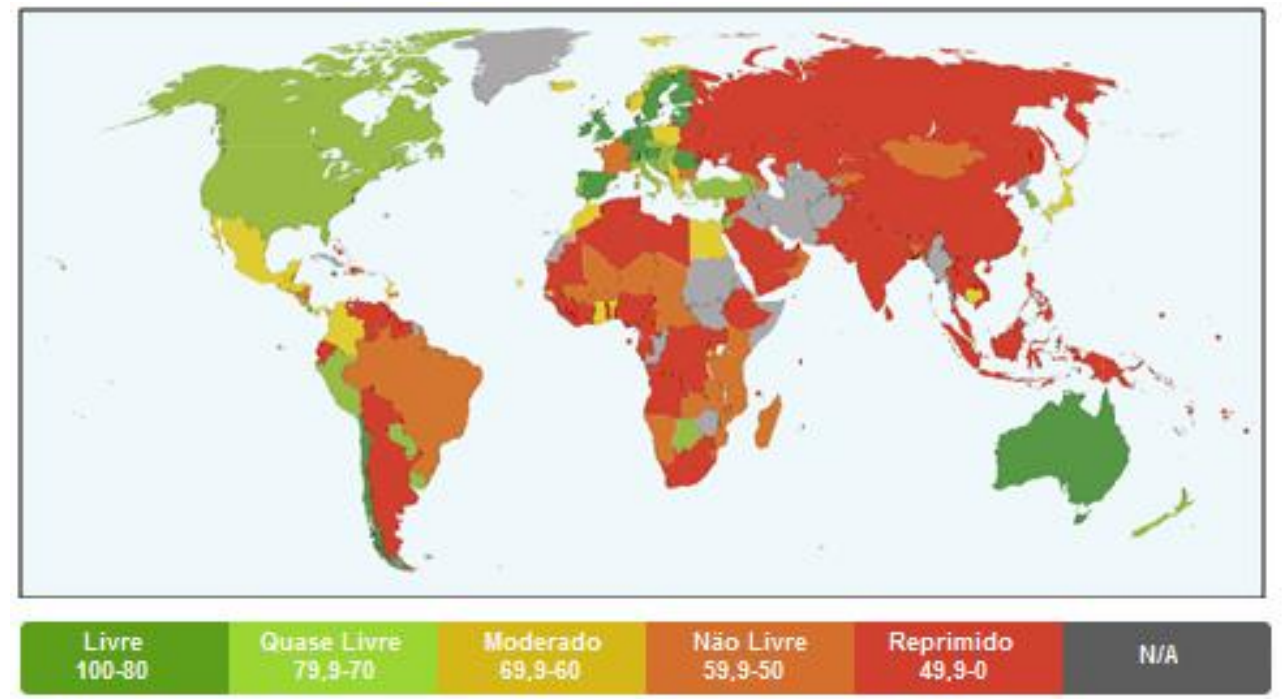

Figura 10 - Classificação dos países segundo indicadores de Liberdade de Investimento Fonte: Heritage Foundation (2011a).

Para fins de aplicação metodológica, as variáveis institucionais acima descritas, definidas pela Heritage Foundation (2011a; 2011b; 2011c), já trazem uma gradação que facilita a definição das dummies. Segundo a Heritage, valores de 0 a 49,9 representam a repressão, inexistência ou insuficiência desses indicadores. Assim sendo, optou-se definir valor igual a zero (0) para

\footnotetext{
27 "In an economically free country, there would be no constraints on the flow of investment capital. Individuals and firms would be allowed to move their resources into and out of specific activities both internally and across the country's borders without restriction." (HERITAGE FOUNDATION, 2011a)
} 
países que apresentam valores de 0 a 49,9 em cada variável ${ }^{28}$ e (1) para países que apresentam valor entre 50 a $100^{29}$.

A outra categoria a ser avaliada se refere aos recursos estratégicos. Esta é composta por duas variáveis:

\section{- Disponibilidade de Terras Agricultáveis}

Esta variável representa o valor e a raridade de um determinado recurso e espera-se que quanto maior for a disponibilidade de terras agricultáveis no país, maior será a tendência do investidor externo realizar suas aplicações, devido à existencia de um recurso estratégico subutilizado. Cabe informar que, segundo o Banco Mundial (2010), a maior parte das terras disponíveis, mais precisamente 45\%, encontra-se na África Subsaariana, 28\% na América Latina e no Caribe e $27 \%$ no Resto do Mundo. Vide Tabela 1, com a distribuição por região da Disponibilidade de Terras.

Tabela 1- Potencial disponibilidade de terras não-cultivadas em diferentes regiões

\begin{tabular}{lr}
\hline & Área (1000 ha) \\
\hline África Subsaariana & 201.761 \\
\hline América Latina e Caribe & 123.342 \\
\hline Europa do Leste e Ásia Central & 51.136 \\
\hline Leste e Sul da Ásia & 14.769 \\
Oriente Médio e Norte da África & 2.716 \\
Resto do Mundo & 52.134 \\
\hline Total & $\mathbf{4 4 5 . 8 5 8}$ \\
\hline
\end{tabular}

Fonte: Fischer; Shah apud Banco Mundial (2010). Dados trabalhados

Da mesma forma que a variável dependente do modelo, a presente variável também foi dicotomizada no ponto mediano entre os valores relativos à disponibilidade de terras agricultável dos 16 países. Ou seja, o limiar da variável Disponibilidade de Terras é o ponto

\footnotetext{
${ }^{28}$ Valores de 0 a 49,9 representam respectivamente a cada variavel: alto ou elevado potencial de expropriação de direitos de propriedade (LEGALF); alto ou elevado grau de corrupção (POLITF); e ausência ou baixo nível de liberdade de investimento (ECONF).

${ }^{29}$ Valores de 50 a 100 representam respectivamente a cada variável: ausência ou baixo potencial de expropriação de direitos de propriedade (LEGALF); ausência ou baixo grau de corrupção (POLITF); ealto ou elevado nível de liberdade de investimento(ECONF).
} 
que divide a metade inferior (oito países com menor disponibilidade) da metade superior (os demais oito países com maior disponibilidade de terras).

\section{- Produtividade da Terra}

Para avaliar a Produtividade da Terra usou-se o rendimento em toneladas por hectare. Estima-se que quanto menor for o rendimento (tons/ha), maior será a tendência do investidor investir nestas localidades. Pode-se inferir que nos países em desenvolvimento, o baixo rendimento deve-se ao uso ineficiente do recurso estratégico terra frente a outros países do mundo (vide Figura 11). Ou seja, estima-se que o baixo rendimento seja um fator de atração de IED, pois o investidor potencial conseguirá extrair de uma determinada área um potencial muito maior do que aquele que vem sendo realizado FAO (2012a).

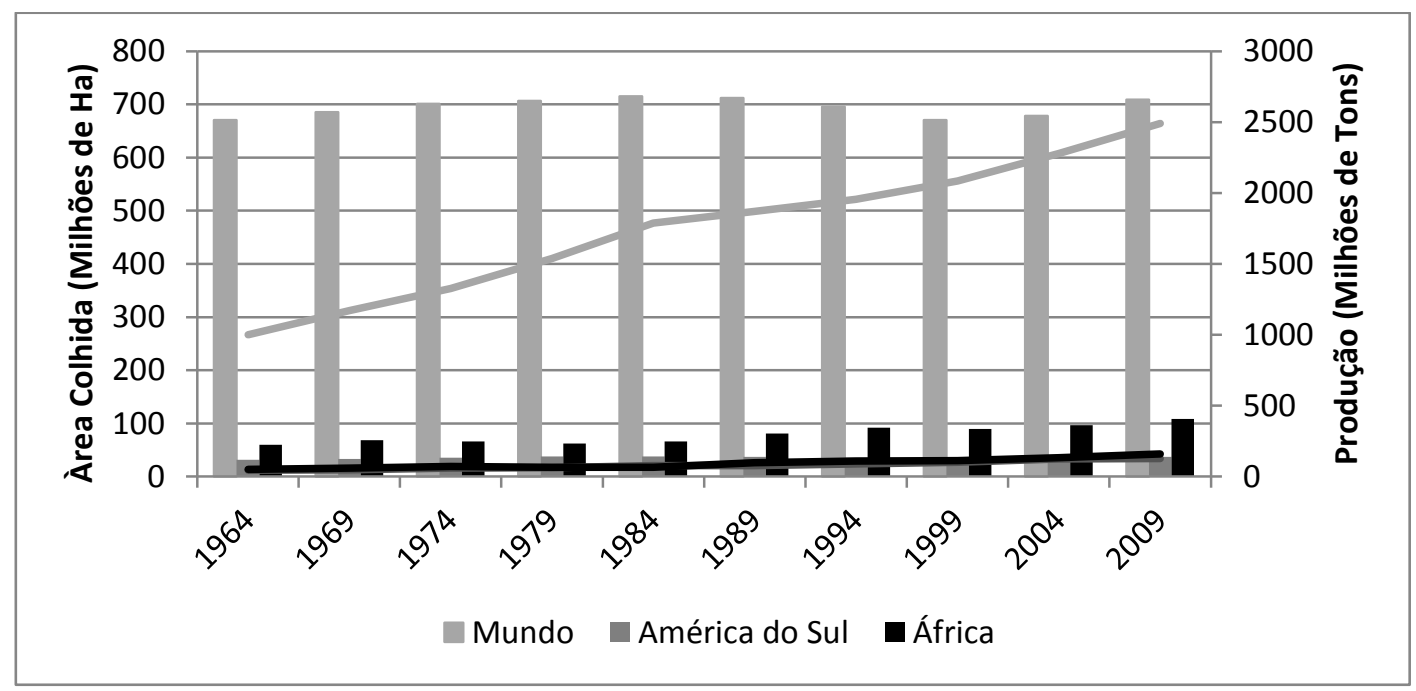

Figura 11 - Área Colhida e Respectiva Produção de Cereais Fonte: FAO (2011, s/p.). Dados Trabalhados

Apenas a critério ilustrativo percebe-se, pela Figura 11, que durante o intervalo de tempo 1964-2009, as áreas colhidas de cereais, no mundo e especificamente na África e América do Sul, se mantiveram relativamente estáveis em número de hectares. Contudo, houve um aumento consideravelmente maior na produção de cereais no mundo, do que nas nações africanas e sulamericanas. Nota-se, portanto, que a produtividade (tons/ha de área colhida) da África e América do Sul são menores do que a do resto do mundo, fato que explicita a diferença existente entre a produção que vem sendo realizada e a produção possível para a mesma área. 
Com a finalidade de se realizar a dicotomização da variável Produtividade da Terra para fins da análise qualitativa, buscou-se balizar a produtividade destas regiões frente à média mundial (vide Tabela 2).

Tabela 2 - Produtividade na produção de cereais das regiões

\begin{tabular}{ll}
\hline Produtividade África (Ton/ha) & 1,479 \\
Produtividade Sul-Americana (Ton/ha) & 3,444 \\
\hline Produtividade Mundo (Ton/ha)* & $\mathbf{3 , 9 1 1}$ \\
\hline
\end{tabular}

Fonte: FAO (2011, s/p.). Dados Trabalhados.

*Mundo, excetuando-se África e América do Sul.

Observa-se que o rendimento mundial ${ }^{30}$ médio por hectare de 3,911 para a produção de cereais (FAO, 2011). Desta maneira, definiu-se o valor de 3,9 como o ponto de inflexão da variável Produtividade da Terra.

O Quadro 1 traz as variáveis e o sinal esperado em cada uma.

Quadro 1 - Descrição das Variáveis do Estudo Qualitativo

\begin{tabular}{|l|l|l|c|}
\hline Outcome (Resultado) & Unidade & Fonte & Var. Esperada \\
\hline $\begin{array}{l}\text { Investimento Externo Direto } \\
\text { per capita (IED) }\end{array}$ & $\begin{array}{l}\text { US\$ per } \\
\text { capita }\end{array}$ & UNCTAD & N.A. \\
\hline Variável & Unidade & Fonte & $\begin{array}{l}\text { Influência } \\
\text { Lógica Esperada }\end{array}$ \\
\hline $\begin{array}{l}\text { hl: Força Legal / Direitos de } \\
\text { Propriedade (LEGALF) }\end{array}$ & $\begin{array}{l}\text { - valores de 0 } \\
\text { a } 100\end{array}$ & $\begin{array}{l}\text { The Wall Street Journal - Heritage } \\
\text { Foundation }\end{array}$ & + \\
\hline $\begin{array}{l}\text { h2: Força Política / Ausência } \\
\text { de Corrupção (POLITF) }\end{array}$ & $\begin{array}{l}\text { - valores de 0 } 100 \\
\text { The Wall Street Journal - Heritage } \\
\text { Foundation }\end{array}$ & + \\
\hline $\begin{array}{l}\text { h3: Força Econômica / } \\
\text { Liberdade de Investimento } \\
\text { (ECONF) }\end{array}$ & $\begin{array}{l}\text { a valores de 0 } 100 \\
\text { The Wall Street Journal - Heritage } \\
\text { FISPONIBILIDADE) }\end{array}$ & $\begin{array}{l}\text { Foundation } \\
\text { terras do total }\end{array}$ & Banco Mundial \\
\hline $\begin{array}{l}\text { h5: Produtividade da Terra } \\
\text { (PRODUTIVIDADE) }\end{array}$ & $\begin{array}{l}\text { Kg per } \\
\text { Hectare }\end{array}$ & Banco Mundial & + \\
\hline
\end{tabular}

Fonte: o próprio autor

3.1.2 - Análise dos determinantes do IED em 2010 segundo a metodologia csQCA

${ }^{30}$ Excetuando África e América do Sul. 
Para realizar a análise estatística pela metodologia de Rihoux e Ragin (2009), inicialmente constrói-se uma tabela no programa TOSMANA (CRONQVIST, 2003, 2007), na qual são realizadas as dicotomizações das variáveis, cujos critérios foram expostos anteriormente. Chega-se assim, à tabela exposta na Figura 12.

\begin{tabular}{|c|c|c|c|c|c|c|c|c|}
\hline \multicolumn{4}{|c|}{ BD_Quali - Tosmana } & & & & & \multirow[t]{2}{*}{\begin{tabular}{|l|l|l|}
$口$ & 回 & $x$ \\
\end{tabular}} \\
\hline File & Data Analysis & \multirow{2}{*}{\multicolumn{2}{|c|}{ About }} & & & & & \\
\hline \multirow[t]{2}{*}{ Data } & Configurations & & & & & & & \\
\hline & Nus Pais Abrev. & Nis País Nome & $\begin{array}{l}\text { InvFree } 10 \\
\text { 昌 } 49.92\end{array}$ & $\begin{array}{l}\text { LegalF } 10 \\
\text { Leg } 49.84\end{array}$ & $\begin{array}{l}\text { PolitF } 10 \\
\text { 品 } 49.9\end{array}$ & $\begin{array}{l}\text { Disponib Terra } \\
\text { 思 } 9056.61\end{array}$ & $\begin{array}{l}\text { Rendim. (ton/ha) } \\
\text { 晶 } 3.9\end{array}$ & $\begin{array}{l}\text { IED per cap } 2010 \\
\text { 輏 } 50.02\end{array}$ \\
\hline \multirow[t]{16}{*}{1} & AGO & Angola & $0(35)$ & $0(20)$ & $0(19)$ & $1(9684)$ & $0(0,51)$ & $1(520,9960092)$ \\
\hline & ARG & Argentina & $0(45)$ & $0(20)$ & $0(29)$ & $1(29500)$ & $1(6.45)$ & $1(156.8041385)$ \\
\hline & $\mathrm{BOL}$ & Bolivia & $0(15)$ & $0(10)$ & $0(30)$ & $0(8317)$ & $0(2,12)$ & $1(62,63640061)$ \\
\hline & BRA & Brazil & $0(45)$ & $1(50)$ & $0(35)$ & 1 (45472) & $1(4,09)$ & $1(248,4682077)$ \\
\hline & BFA & Burkina Faso & $1(50)$ & $0(30)$ & $0(35)$ & $0(3713)$ & $0(1,67)$ & $0(2,254427451)$ \\
\hline & CAF & Central African R... & $0(40)$ & $0(20)$ & $0(20)$ & $0(7940)$ & $0(1,09)$ & $0(16,36785228)$ \\
\hline & TCD & Chad & $0(45)$ & $0(20)$ & $0(16)$ & $1(14816)$ & $0(0,96)$ & $1(69,5958327)$ \\
\hline & ETH & Ethiopia & $0(25)$ & $0(30)$ & $0(26)$ & $0(4726)$ & $0(2,14)$ & $0(2,218216012)$ \\
\hline & MDG & Madagascar & $1(60)$ & $0(45)$ & $0(34)$ & $1(16244)$ & $0(1,48)$ & $0(41.53677879)$ \\
\hline & MEX & Mexico & $1(65)$ & $1(50)$ & $0(36)$ & $0(4360)$ & $0(3,31)$ & $1(164,6867237)$ \\
\hline & MOZ & Mozambique & $1(50)$ & $0(30)$ & $0(26)$ & $1(16256)$ & $0(0,92)$ & $0(33,72504339)$ \\
\hline & PRY & Paraguay & $1(65)$ & $0(30)$ & $0(24)$ & 0 (7269) & $0(2,24)$ & $1(64,8689885)$ \\
\hline & ZAF & South Africa & $0(45)$ & $1(50)$ & $0(49)$ & $0(3555)$ & $1(4,14)$ & $0(30,97810865)$ \\
\hline & URY & Uruguay & $1(75)$ & $1(75)$ & 1 (69) & 1 (9269) & $1(4,15)$ & $0(29.95113592)$ \\
\hline & VEM & Venezuela & $0(5)$ & $0(0)$ & $0(19)$ & $0(8966)$ & $0(3,47)$ & $0(-48,447444403)$ \\
\hline & ZMB & Zambia & $1(50)$ & $0(30)$ & $0(28)$ & $1(13020)$ & $0(2,18)$ & $1(79.56560572)$ \\
\hline 米 & & & & & & & & \\
\hline
\end{tabular}

Figura 12 - Dados Dicotomizados no software TOSMANA

Fonte: do autor. Dados aplicados no software TOSMANA (CRONQVIST, 2003, 2007)

Note que ao lado do nome de cada variável encontra-se o valor definido para a dicotomização. Assim, o programa mantém a transparência das análises a serem realizadas.

Após a construção da tabela com as dummies, os próximos passos consistem em rodar as análises a partir dos resultados imputados. Ao se extrair a Tabela Verdade (Tabela 3), consegue-se identificar as particularidades de cada caso segundo as variáveis que se está trabalhando, de forma a relacioná-las com seu outcome $(\mathrm{O})$, que nada mais é do que o nível (alto ou baixo) do IED que receberam. 


\begin{tabular}{|c|c|c|c|c|c|c|}
\hline \multicolumn{7}{|c|}{ Tabela 3 - Tabela Verdade } \\
\hline v1: & \multirow{2}{*}{\multicolumn{2}{|c|}{$\begin{array}{l}\text { InvFree } 10 \\
\text { PolitF } 10 \\
\text { Yield ton (Maize) }\end{array}$}} & v2: & \multicolumn{3}{|c|}{ LegalF 10} \\
\hline $\begin{array}{l}\text { v3: } \\
\text { v5: }\end{array}$ & & & v4: & Dis & Terr & \\
\hline O: & \multicolumn{2}{|c|}{ IED per cap 2010} & id: & \multicolumn{2}{|l|}{ Id } & \\
\hline v1 & v2 & v3 & $\mathrm{v} 4$ & v5 & 0 & id \\
\hline 0 & 0 & 0 & 1 & 0 & 1 & $\mathrm{AGO}, \mathrm{TCD}$ \\
\hline 0 & 0 & 0 & 1 & 1 & 1 & $\mathrm{ARG}$ \\
\hline 0 & 0 & 0 & 0 & 0 & $\mathrm{C}$ & BOL,CAF,ETH,VEM \\
\hline 0 & 1 & 0 & 1 & 1 & 1 & BRA \\
\hline 1 & 0 & 0 & 0 & 0 & $\mathrm{C}$ & BFA.PRY \\
\hline 1 & 0 & 0 & 1 & 0 & $\mathrm{C}$ & MDG.MOZ.ZMB \\
\hline 1 & 1 & 0 & 0 & 0 & 1 & MEX \\
\hline 0 & 1 & 0 & 0 & 1 & 0 & $\mathrm{ZAF}$ \\
\hline 1 & 1 & 1 & 1 & 1 & 0 & URY \\
\hline
\end{tabular}

Fonte: Software TOSMANA (CRONQVIST, 2003, 2007)

De acordo com Rihoux e Ragin (2009), a tabela verdade expõe cinco diferentes tipos de configurações de resultados:

[1] resultado (outcome) - casos de alto nível de IED.

[0] resultado (outcome) - casos de baixo nível de IED.

[-] resultado "indefinido" ("don't care" outcome) - casos com missing values. ${ }^{31}$

[C] Resultado de casos contraditórios - significa que uma mesma configuração lógica de variáveis explicativas levou alguns casos a um resultado [1 - alto nível de IED] e outros a um resultado distinto [0 - baixo nível de IED].

[L] or [R] Resultados de lembretes lógicos - estes indicam possíveis sequências lógicas que não foram observadas dentro dos casos presentes na amostra. ${ }^{32}$

Voltando a análisar os resultados da tabela verdade, pode-se observar que pelos 16 casos iniciais foram encontradas nove configurações lógicas diferentes, a saber:

Existem quatro configurações distintas para resultado [1] (alto nível de IED),

\footnotetext{
${ }^{31}$ Este caso especial não será encontrado na amostra, pois todos os casos incluídos têm um nível de IED explicitado já de início.

32 Segundo os autores Rihoux e Ragin ( 2009), a presença de lembretes lógicos na formatação da análise dá maior robustez ao resultado, pois considera expressões lógicas possíveis de existirem, mas que não estão presentes na amostra.
} 
respectivamente: Angola (AGO), Chad (TCD); Argentina (ARG), Brasil (BRA) e México (MEX).

Existem duas configurações distintas para resultado [0] (baixo nível de IED), respectivamente: África do Sul (ZAF) e Uruguai (URY).

Existem três configurações distintas para resultado [C] (resultado contraditório), respectivamente: Bolívia (BOL), República Centro Africana (CAF), Etiópia (ETH), Venezuela (VEN), Burkina Faso (BFA), Paraguai (PRY), Madagascar (MDG), Moçambique (MOZ) e Zambia (ZMB).

De imediato nota-se que a amostra tem uma limitação: apenas sete casos em 16 foram passíveis de uma explicação direta pelas configurações lógicas. A maioria dos casos (nove) se situam em um configuração contraditória [C]. Tal resultado preliminar apresentado pela Tabela Verdade (truth table) demonstra, dentre outros fatores, a complexidade do objeto estudado e principalmente revela que os resultados qualitativos aqui presentes não devem ser generalizados, mas sim construídos para entender a situação particular de cada um dos 16 países.

Feitas as ressalvas, a geração dos resultados da análise qualitativa ocorre com base na tabela verdade (truth table). Por meio de iterações contínuas, o software TOSMANA (CRONQVIST, 2003; 2007) estabelece sentenças matemáticas simples, que definem as variáveis necessárias e suficientes para o resultado desejado (alto nível de IED). Na Tabela 4 encontra-se a expressão lógica final do modelo.

Tabela 4 - Resultado csQCA

\begin{tabular}{c}
\hline Solução(1): produtividade (ton/ha) + econf * DISPONIB TERRA \\
Solução(2): produtividade (ton/ha) + politf* DISPONIB TERRA \\
produtividade (ton/ha): Condição Suficiente \\
DISPONIB TERRA: Condição Estratégica \\
\hline
\end{tabular}

Fonte: o próprio autor. Dados aplicados no software TOSMANA (CRONQVIST, 2003, 2007)

Primeiramente, quando se incluem as contradições e os lembretes lógicos, conforme recomendam Rihoux e Ragin (2009), pode-se observar que o modelo propicia duas configurações lógicas capazes de explicar o resultado [1] (alto nível de IED). Observa-se que 
em ambos os casos a existência de uma baixa Produtividade da terra (ton/ha) (h4) nos países alvo é condição suficiente para a existência de um alto nível de IED.

Verifica-se, portanto, que o investidor externo prefere aplicar seu capital em regiões que ainda tem uma brecha de produtividade (produção/área colhida) conforme era esperado. Pode-se inferir que a brecha de rendimento existente é suficiente para atrair o investidor, pois este 'julga' (CASSON, 2005; FOSS, et al., 2007; KEYNES, 1983) um potencial de geração de rendas econômicas pela posse de um recurso ainda sub-utilizado, que o permite gerar vantagens comparativas. Tal consideração alinha-se com a literatura da TBR, sobretudo nos trabalhos de Barney e Clark (2007).

Não obstante, pelas expressões lógicas pode-se inferir que a alta disponibilidade de terras [1], quando associada a uma baixa liberdade de investimento (invfree [0]) ou à presença de um nível mais elevado de corrupção (politf [0]), determinam um alto nível de IED. Não se pode inferir que a alta Disponibilidade de terra $(h 4)$ é uma condição necessária, mas sim uma condição estratégica, pois quando vinculada as características institucionais acima descritas traduzem-se em uma condição suficiente.

Estima-se, a partir dos resultados, que estando os recursos em países em desenvolvimento, em geral o acesso à terra e, principalmente, a grandes extensões, não se dá de maneira "simples". Dessa forma, por vezes, a fraqueza institucional como corrupção e barreiras à entrada de investimento podem atuar de forma positiva para investidores de grande porte. Como estes podem potencialmente usar tais debilidades institucionais para entrar mais facilmente no país e potencialmente "capturarem o Estado" a seu favor (STIGLER, 1971), tais debilidades institucionais podem vir a ser utilizados favoravelmente. Este fato explicaria porque a alta disponibilidade de terras deveria estar relacionada com barreiras ao investimento ou à corrupção, conforme apresentou o modelo QCA.

Por fim, pode-se inferir que a análise qualitativa possibilitou a observação da importância que os recursos têm na realização do investimento externo. Apesar de só haver sido analisado um número pequeno de países, em um único ano, e dos quais muitos casos se constituíram como contradições; o modelo permite tal constatação. É possível observar que a literatura da TBR é condizente com a realidade do movimento de investimentos externos em terras. 
3.2 - Análise Estatística Quantitativa e os determinantes do IED, 2000-2010

A análise estatística a seguir está fundamentada em métodos quantitativos de corte transversal, fazendo usos de dados secundários oriundos de organismos e fundações internacionais ${ }^{33}$. Para tanto, utilizou-se a análise de dados em painel de efeitos fixos e aleatórios. A presente técnica permite verificar alterações na variável dependente a partir de mudanças nas variáveis explicativas, que ocorrem ao longo do tempo, e entre os diferentes casos estudados (WOOLDRIDGE, 2006). Dessa forma, foi possível analisar quais variáveis são significativamente determinantes na alteração do IED ao longo do período considerado (de 2000 a 2010).

A técnica de dados em painel de efeito fixo é indicada para a presente pesquisa, pois ela corrige eventuais problemas de endogeneidade, sem a necessidade de variáveis instrumentais (HAMILTON; NICKERSON, 2001). Nas palavras de Wooldridge (2006):

Sob uma hipótese de exogeneidade estrita das variáveis explicativas, o estimador de efeitos fixos é não viesado: grosso modo, o erro idiossincrático $u_{i t}$ deve ser não correlacionado com cada variável explicativa ao longo de todos os períodos de tempo. (WOOLDRIDGE, 2006, p.434)

Outro ponto relevante para o uso de modelos em formato de painel de efeitos fixos está na possibilidade de interação entre variáveis, sobretudo interação com variáveis anuais, com a finalidade de verificar possíveis impactos ocorridos em um dado período. Segundo Wooldridge (2006):

Embora variáveis constantes no tempo não possam ser incluídas por si mesmas em um modelo de efeitos fixos, elas podem interagir com variáveis que mudam ao longo do tempo e, particularmente com variáveis dummy anuais. (WOOLDRIDGE, 2006, p.436)

Já o painel de efeito aleatório é vantajoso, pois "considera variáveis explicativas que sejam constantes ao longo do tempo" (WOOLDIDGE, 2006, p.442). Tal fato é pertinente à pesquisa,

\footnotetext{
${ }^{33}$ Dentre elas: a Conferência das Nações Unidas sobre Comércio e Desenvolvimento (UNCTAD), o Banco
} Mundial e a Heritage Foundation -Wall Street Journal. 
sobretudo porque no presente modelo são incluídas variáveis institucionais, que tendem a variar em horizontes temporais de dez a 100 anos (WILLIAMSON, 2000).

Fundamentando-se sobre as premissas acima descritas, buscou-se estruturar o modelo de dados em painel de efeito fixo e aleatório (eq. 1), de modo a verificar as cinco hipóteses do trabalho.

IED $_{i t}=\beta_{0}+\beta_{1}$ LEGALF $_{i t}+\beta_{2}$ POLITF $_{i t}+\beta_{3}$ ECONF $_{i t}+\beta_{4}$ Disponibilidade $_{i t}+$ $\beta_{5}$ Produtividade $_{i t}+\gamma K_{i t}+u_{i t}$

Onde $\mathrm{K}$ = vetor de variáveis de controle.

\subsection{1 - Variáveis e Resultados do Modelo Quantitativo}

As variáveis explicativas utilizadas nos modelos de painel serão as mesmas utilizadas no modelo qualitativo csQCA: $(h 1)$ LEGALF - Direitos de Propriedade; (h2) POLITF - Ausência de Corrupção, (h3) ECONF - Liberdade de Investimentos; (h4) Disponibilidade de Terras Agricultáveis; e (h5) Produtividade da Terra ${ }^{34}$. Abaixo serão expostas as demais variáveis utilizadas no modelo quantitativo, unicamente com a função de controle das equações.

\section{- PIB Agrícola per capita (PIBAgro)}

O PIB Agrícola, ou seja, o total produzido por agricultura, caça, silvicultura e pesca de um país, em um determinado período, foi incluído no modelo como variável de controle. Conforme relatado na literatura sobre IED, variáveis macroeconômicas como (PIB, câmbio, inflação, balança comercial, dentre outras) são determinantes no nível de atração do investimento externo (AMAL, SEABRA, 2007; DUNNING, 2001; SERVEN, SOLIMANO, 1993). Os dados referentes à variável PIB Agrícola foram coletados na UNCTAD, de 2000 a

\footnotetext{
${ }^{34}$ Contudo, sem serem realizadas as dicotomizações necessárias à técnica $c s Q C A$.
} 
2010, e ponderadas pela população dos respectivos países. Estima-se que haja uma relação positiva entre IED e PIBAgro.

\section{- Taxa de Câmbio (Câmbio)}

A taxa de câmbio oficial é outra variável de controle no modelo. Esta variável foi coletada na base de dados do Banco Mundial para os 75 países da amostra relativamente a cada ano, respeitando a paridade da moeda local com o dólar americano no respectivo período. Estimase que exista uma relação negativa entre câmbio e IED. Ou seja, uma depreciação da moeda local deve elevar os investimentos pelo ganho no poder de compra dos investidores estrangeiros.

- Taxa de Inflação (Inflação)

A taxa de inflação também está incluída no presente modelo. Dado que a variável dependente do modelo (IED) está em valores monetários relativos ao período considerado, a taxa de inflação (\%) medida no preço cobrado aos consumidores locais foi utilizada com a finalidade de controle macroeconômico exógeno, ao diminuir o viés de variável omitida, seguindo a literatura que trata de IED (AMAL, SEABRA, 2007; DUNNING, 2001; SERVEN, SOLIMANO, 1993). A taxa de inflação foi coletada também na base de dados do Banco Mundial e estima-se que exista uma relação inversa entre inflação e IED, isto é, em países com maior inflação haverá menores aplicações externas.

- Taxa de Juros (Juros)

A taxa de juros oficial de cada país é outra variável de controle no modelo. Esta variável foi coletada na base de dados do Banco Mundial para os 75 países da amostra relativamente a cada ano em pontos percentuais. Estima-se que exista uma relação positiva entre taxa de juros e IED. Ou seja, um aumento nos juros internos do país deve elevar os investimentos pela maior possibilidade de ganho em decorrência desta diferença de rendimentos. 
- Balança Comercial (ComEx)

Outra variável macroeconômica incluída para efeitos de controle é a balança comercial, isto é, o valor das exportações de bens frente às importações realizadas em um mesmo período. Foi coletado no Banco Mundial o valor líquido anual em dólares americanos obtidos no comércio de bens de cada um dos países da amostra e para cada um dos anos considerados. Estima-se uma relação negativa entre balança comercial e IED porque se o mercado for a estrutura de governança que minimize os custos de transação (WILLIAMSON, 1996), uma balança comercial positiva indicaria uma menor necessidade de integralização de investimentos por meio dos não-nacionais, o que levaria a uma diminuição do nível de IED.

\section{- Commodity Index (CommodityIndex)}

O índice de preços de commodities agrícolas relativas a bens alimentícios foi também incluído como variável de controle no modelo, justamente por sua intrínseca relação com investimentos estrangeiros em terras agricultáveis. Esta relação ocorre, pois, a atração de IED depende não apenas pelo que o país de destino tem a oferecer, mas também em decorrência da conjuntura internacional dos preços alimentícios. Sendo assim, é também importante controlar esta variação no modelo proposto, a fim de diminuir o viés de variável omitida. Os dados foram coletados nas bases da UNCTAD e medem o índice anual de preços das commodities alimentícias no mercado spot ponderado pelo ano base (2000). Os dados foram coletados para cada ano da amostra (2000 a 2010). Espera-se que um aumento nos preços das commodities alimentícias acarrete um aumento do IED.

\section{- Dummy Regional (dAmérica)}

A dummy regional, diferenciando países da América do Sul, Central e Caribe dos países da África Sub Saariana, foi realizada com a finalidade de controle. Tal indicador também poderá mostrar se existem diferenças significativas entre o nível de IED aplicado ano a ano nos países americanos frente aos africanos.

- Dummies Anuais (dAno) 
Dummies anuais para o período de 2000 a 2010 também foram inseridas com a finalidade de controle, de modo a expor a evolução dos investimentos ao longo do tempo. Vale ressaltar que o ano de 2010 foi tomado como ano base na análise e, portanto, aparece omitido nos resultados do modelo. O Quadro 2 expõe as variáveis incluídas nos modelos de painel, bem como a variação esperada em cada uma das variáveis explicativas do modelo.

\begin{tabular}{|c|c|c|c|}
\hline $\begin{array}{c}\text { Variável } \\
\end{array}$ & Unidade & Fonte & Var. Esperada \\
\hline $\begin{array}{l}\text { Investimento Externo Direto per } \\
\text { capita (IED) }\end{array}$ & US\$ per capita & UNCTAD & Var.Dependente \\
\hline $\begin{array}{l}\text { h1: Força Legal / Direitos de } \\
\text { Propriedade (LEGALF) }\end{array}$ & $\begin{array}{l}- \text { valores de } 0 \text { a } \\
100\end{array}$ & $\begin{array}{l}\text { The Wall Street Journal - Heritage } \\
\text { Foundation }\end{array}$ & + \\
\hline $\begin{array}{l}\text { h2: Força Política / Ausência de } \\
\text { Corrupção (POLITF) }\end{array}$ & $\begin{array}{l}\text { - valores de } 0 \text { a } \\
100\end{array}$ & $\begin{array}{l}\text { The Wall Street Journal - Heritage } \\
\text { Foundation }\end{array}$ & + \\
\hline $\begin{array}{l}\text { h3: Força Econômica / Liberdade de } \\
\text { Investimento (ECONF) }\end{array}$ & $\begin{array}{l}- \text { valores de } 0 \text { a } \\
100\end{array}$ & $\begin{array}{l}\text { The Wall Street Journal - Heritage } \\
\text { Foundation }\end{array}$ & + \\
\hline $\begin{array}{lcc}h 4: & \text { Terra } & \text { Agricultável } \\
\text { (DISPONIBILIDADE) } & \end{array}$ & $\%$ do total terras & Banco Mundial & + \\
\hline $\begin{array}{lccc}\text { h5: } & \text { Produtividade } & \text { da } & \text { Terra } \\
\text { (PRODUTIVIDADE) } & & \\
\end{array}$ & Kg per Hectare & Banco Mundial & - \\
\hline PIB Agrícola per capita (PIBAgro) & US\$ per capita & UNCTAD & Var.Controle \\
\hline Taxa de Câmbio (Câmbio) & U\$ & Banco Mundial & Var.Controle \\
\hline Taxa de Inflação (Inflação) & $\%$ & Banco Mundial & Var.Controle \\
\hline Taxa de Juros (Juros) & $\%$ & Banco Mundial & Var.Controle \\
\hline Balança Comercial (ComEx) & U\$ & Banco Mundial & Var.Controle \\
\hline $\begin{array}{lc}\begin{array}{l}\text { Commodity } \\
\text { (CommodityIndex })\end{array} & \text { Index } \\
\end{array}$ & Índice & UNCTAD & Var.Controle \\
\hline Dummy Regional (d'América) & & & Var.Controle \\
\hline Dummies Anuais (d'Ano) & & & Var.Controle \\
\hline
\end{tabular}

Fonte: o próprio autor.

Na sequência, são expostos os resultados dos modelos de painel de efeito fixo e aleatório (vide Tabela 5). Ao todo foram realizados oito modelos distintos, quatro modelos de efeito aleatório (RE) e quatro de efeito fixo $(\mathrm{FE}) .{ }^{35}$ As variáveis de controle foram incluídas gradualmente nos modelos. Por fim, vale destacar que foi rodado um modelo estando o IED log-linearizado.

35 Tal medida permite verificar isoladamente as variações temporais (efeito fixo); as variações temporais conjuntamente às variações entre países (efeito aleatório). Vale destacar que as análises foram realizadas com robustez de cluster entre os países. Por fim, nem todos os 75 países foram incluídos nos painéis devido à existência de missing values, de modo que nos modelos conseguiram incluir entre 69 a 51 países nos painéis. 
Tabela 5 - Resultado Modelos Painel de Efeito Fixo e Aleatório

\begin{tabular}{|c|c|c|c|c|c|c|c|c|}
\hline VARIÁVEIS & $\begin{array}{l}(1) \mathrm{RE} \\
\mathrm{IED}\end{array}$ & $\begin{array}{c}(2) \mathrm{FE} \\
\text { IED }\end{array}$ & $\begin{array}{c}(3) \mathrm{RE} \\
\mathrm{IED}\end{array}$ & $\begin{array}{c}(4) \mathrm{FE} \\
\text { IED }\end{array}$ & $\begin{array}{c}(5) \mathrm{RE} \\
\mathrm{IED}\end{array}$ & $\begin{array}{c}(6) \mathrm{FE} \\
\text { IED }\end{array}$ & $\begin{array}{l}(7) \mathrm{RE} \\
\ln \text { IED }\end{array}$ & $\begin{array}{l}(8) \mathrm{FE} \\
\text { ln IED }\end{array}$ \\
\hline LEGALF & $\begin{array}{l}3.562 * * \\
(1.669)\end{array}$ & $\begin{array}{c}1.484 \\
(1.344)\end{array}$ & $\begin{array}{c}4.124 * * * \\
(1.570)\end{array}$ & $\begin{array}{l}2.333^{*} \\
(1.360)\end{array}$ & $\begin{array}{c}4.124 * * * \\
(1.570)\end{array}$ & $\begin{array}{l}2.333^{*} \\
(1.360)\end{array}$ & $\begin{array}{l}0.0156^{* *} \\
(0.00680)\end{array}$ & $\begin{array}{c}0.00830 \\
(0.00743)\end{array}$ \\
\hline POLITF & $\begin{array}{c}2.131 \\
(2.283)\end{array}$ & $\begin{array}{l}0.0714 \\
(1.876)\end{array}$ & $\begin{array}{c}3.381 \\
(3.216)\end{array}$ & $\begin{array}{c}1.279 \\
(2.744)\end{array}$ & $\begin{array}{c}3.381 \\
(3.216)\end{array}$ & $\begin{array}{c}1.279 \\
(2.744)\end{array}$ & $\begin{array}{c}0.0120 \\
(0.0100)\end{array}$ & $\begin{array}{l}0.00521 \\
(0.0106)\end{array}$ \\
\hline ECONF & $\begin{array}{l}-0.290 \\
(0.907)\end{array}$ & $\begin{array}{c}0.162 \\
(0.860)\end{array}$ & $\begin{array}{c}0.208 \\
(0.998)\end{array}$ & $\begin{array}{c}0.722 \\
(1.086)\end{array}$ & $\begin{array}{c}0.208 \\
(0.998)\end{array}$ & $\begin{array}{c}0.722 \\
(1.086)\end{array}$ & $\begin{array}{l}0.00896 * \\
(0.00476)\end{array}$ & $\begin{array}{c}0.00841 \\
(0.00510)\end{array}$ \\
\hline DISPONIBILIDADE & $\begin{array}{c}-4.883^{* *} \\
(2.245)\end{array}$ & $\begin{array}{c}-12.09 * * \\
(4.748)\end{array}$ & $\begin{array}{c}-6.225^{* *} \\
(2.809)\end{array}$ & $\begin{array}{c}-17.06^{* *} \\
(7.224)\end{array}$ & $\begin{array}{c}-6.225^{* *} \\
(2.809)\end{array}$ & $\begin{array}{c}-17.06^{* *} \\
(7.224)\end{array}$ & $\begin{array}{l}-0.0131 * \\
(0.00764)\end{array}$ & $\begin{array}{c}0.0511 \\
(0.0360)\end{array}$ \\
\hline PRODUTIVIDADE & $\begin{array}{l}0.00247 \\
(0.0145)\end{array}$ & $\begin{array}{c}0.0290 \\
(0.0362)\end{array}$ & $\begin{array}{c}-0.00489 \\
(0.0151)\end{array}$ & $\begin{array}{c}0.0211 \\
(0.0413)\end{array}$ & $\begin{array}{r}-0.00489 \\
(0.0151)\end{array}$ & $\begin{array}{c}0.0211 \\
(0.0413)\end{array}$ & $\begin{array}{c}8.49 \mathrm{e}-05 \\
(0.000117)\end{array}$ & $\begin{array}{c}8.28 \mathrm{e}-05 \\
(0.000192)\end{array}$ \\
\hline PIBAgro & $\begin{array}{l}-3.264 \\
(3.391)\end{array}$ & $\begin{array}{l}-4.227 \\
(4.660)\end{array}$ & $\begin{array}{l}-4.678 \\
(3.562)\end{array}$ & $\begin{array}{l}-5.596 \\
(4.619)\end{array}$ & $\begin{array}{l}-4.678 \\
(3.562)\end{array}$ & $\begin{array}{l}-5.596 \\
(4.619)\end{array}$ & $\begin{array}{c}0.00551 \\
(0.00808)\end{array}$ & $\begin{array}{c}-0.000672 \\
(0.0102)\end{array}$ \\
\hline Câmbio & $\begin{array}{c}-0.00725^{*} \\
(0.00381)\end{array}$ & $\begin{array}{r}-0.00773 \\
(0.0282)\end{array}$ & $\begin{array}{l}-0.00610 \\
(0.00402)\end{array}$ & $\begin{array}{l}-0.0251 \\
(0.0335)\end{array}$ & $\begin{array}{l}-0.00610 \\
(0.00402)\end{array}$ & $\begin{array}{l}-0.0251 \\
(0.0335)\end{array}$ & $\begin{array}{l}-2.08 \mathrm{e}-05 \\
(3.20 \mathrm{e}-05)\end{array}$ & $\begin{array}{c}-0.000256 \\
(0.000199)\end{array}$ \\
\hline Inflação & $\begin{array}{l}-0.00227 \\
(0.00177)\end{array}$ & $\begin{array}{c}-0.00200 \\
(0.0106)\end{array}$ & $\begin{array}{l}-0.610 \\
(0.589)\end{array}$ & $\begin{array}{l}-1.055 \\
(0.647)\end{array}$ & $\begin{array}{l}-0.610 \\
(0.589)\end{array}$ & $\begin{array}{l}-1.055 \\
(0.647)\end{array}$ & $\begin{array}{c}3.27 \mathrm{e}-05^{* *} \\
(1.41 \mathrm{e}-05)\end{array}$ & $\begin{array}{c}0.000125 \\
(8.07 \mathrm{e}-05)\end{array}$ \\
\hline Juros & & & $\begin{array}{c}-3.555^{* *} \\
(1.607)\end{array}$ & $\begin{array}{l}-2.059 \\
(2.834)\end{array}$ & $\begin{array}{c}-3.555^{* *} \\
(1.607)\end{array}$ & $\begin{array}{l}-2.059 \\
(2.834)\end{array}$ & & \\
\hline ComEx & & & $\begin{array}{l}-1.34 \mathrm{e}-09 \\
(2.45 \mathrm{e}-09)\end{array}$ & $\begin{array}{l}-1.39 \mathrm{e}-09 \\
(2.15 \mathrm{e}-09)\end{array}$ & $\begin{array}{l}-1.34 \mathrm{e}-09 \\
(2.45 \mathrm{e}-09)\end{array}$ & $\begin{array}{l}-1.39 \mathrm{e}-09 \\
(2.15 \mathrm{e}-09)\end{array}$ & & \\
\hline CommodityIndex & & & & & & $\begin{array}{c}2.545 * * * \\
(0.755)\end{array}$ & & \\
\hline dAmerica & $\begin{array}{c}170.2 * * \\
(67.96)\end{array}$ & & $\begin{array}{c}140.2 * * \\
(65.42)\end{array}$ & & $\begin{array}{c}140.2 * * \\
(65.42)\end{array}$ & & $\begin{array}{c}1.274 * * * \\
(0.371)\end{array}$ & \\
\hline d2000 & $\begin{array}{c}-151.4 * * * \\
(48.38)\end{array}$ & & $\begin{array}{c}-190.5^{* * * *} \\
(58.77)\end{array}$ & & $\begin{array}{c}-190.5 * * * \\
(58.77)\end{array}$ & & $\begin{array}{c}-0.971 * * * \\
(0.167)\end{array}$ & \\
\hline d2001 & $\begin{array}{c}-143.6^{* * * *} \\
(46.77)\end{array}$ & $\begin{array}{c}7.058 \\
(11.19)\end{array}$ & $\begin{array}{c}-195.4 * * * \\
(58.61)\end{array}$ & $\begin{array}{l}-5.841 \\
(11.06)\end{array}$ & $\begin{array}{c}-195.4 * * * \\
(58.61)\end{array}$ & $\begin{array}{l}-4.929 \\
(11.13)\end{array}$ & $\begin{array}{c}-1.163 * * * \\
(0.198)\end{array}$ & $\begin{array}{l}-0.212 \\
(0.138)\end{array}$ \\
\hline $\mathrm{d} 2002$ & $\begin{array}{c}-138.4 * * * \\
(51.51)\end{array}$ & $\begin{array}{c}7.879 \\
(20.41)\end{array}$ & $\begin{array}{c}-183.4 * * * \\
(66.87)\end{array}$ & $\begin{array}{c}0.914 \\
(24.88)\end{array}$ & $\begin{array}{c}-183.4 * * * \\
(66.87)\end{array}$ & $\begin{array}{l}-5.555 \\
(25.40)\end{array}$ & $\begin{array}{c}-1.140 * * * \\
(0.209)\end{array}$ & $\begin{array}{l}-0.190 \\
(0.161)\end{array}$ \\
\hline d2003 & $\begin{array}{c}-106.8 * * * \\
(31.36)\end{array}$ & $\begin{array}{c}38.56 \\
(24.43)\end{array}$ & $\begin{array}{c}-133.4 * * * \\
(37.20)\end{array}$ & $\begin{array}{l}53.28 * \\
(30.71)\end{array}$ & $\begin{array}{c}-133.4 * * * \\
(37.20)\end{array}$ & $\begin{array}{c}36.06 \\
(27.09)\end{array}$ & $\begin{array}{c}-0.930 * * * \\
(0.161)\end{array}$ & $\begin{array}{c}0.00310 \\
(0.137)\end{array}$ \\
\hline d2004 & $\begin{array}{c}-83.57 * * * \\
(30.56)\end{array}$ & $\begin{array}{l}63.82 * * \\
(27.09)\end{array}$ & $\begin{array}{c}-104.8 * * * \\
(36.73)\end{array}$ & $\begin{array}{c}84.35 * * \\
(35.09)\end{array}$ & $\begin{array}{c}-104.8 * * * \\
(36.73)\end{array}$ & $\begin{array}{c}31.30 \\
(25.07)\end{array}$ & $\begin{array}{c}-0.735 \text { *** } \\
(0.159)\end{array}$ & $\begin{array}{c}0.181 \\
(0.140)\end{array}$ \\
\hline d2005 & $\begin{array}{c}-33.75^{*} \\
(18.47)\end{array}$ & $\begin{array}{c}110.7 * * * \\
(41.47)\end{array}$ & $\begin{array}{l}-41.59 * \\
(22.61)\end{array}$ & $\begin{array}{c}144.5^{* *} \\
(56.62)\end{array}$ & $\begin{array}{l}-41.59 * \\
(22.61)\end{array}$ & $\begin{array}{l}72.09^{*} \\
(39.48)\end{array}$ & $\begin{array}{c}-0.388 * * * \\
(0.137)\end{array}$ & $\begin{array}{c}0.514 * * * \\
(0.162)\end{array}$ \\
\hline d2006 & $\begin{array}{c}3.261 \\
(17.95)\end{array}$ & $\begin{array}{c}149.0 * * * \\
(54.46)\end{array}$ & $\begin{array}{c}12.38 \\
(28.16)\end{array}$ & $\begin{array}{c}200.4^{* *} \\
(77.53)\end{array}$ & $\begin{array}{c}12.38 \\
(28.16)\end{array}$ & $\begin{array}{c}74.80 \\
(47.09)\end{array}$ & $\begin{array}{l}-0.239 \\
(0.151)\end{array}$ & $\begin{array}{c}0.683 * * * \\
(0.190)\end{array}$ \\
\hline d2007 & $\begin{array}{c}45.57 * * \\
(21.67)\end{array}$ & $\begin{array}{c}192.9 * * * \\
(64.00)\end{array}$ & $\begin{array}{l}61.98^{*} \\
(33.92)\end{array}$ & $\begin{array}{c}251.4^{* * * *} \\
(87.21)\end{array}$ & $\begin{array}{l}61.98^{*} \\
(33.92)\end{array}$ & $\begin{array}{l}75.12 * \\
(44.75)\end{array}$ & $\begin{array}{c}0.166 \\
(0.102)\end{array}$ & $\begin{array}{c}1.069 * * * \\
(0.170)\end{array}$ \\
\hline $\mathrm{d} 2008$ & $\begin{array}{c}105.4 * * * \\
(36.84)\end{array}$ & $\begin{array}{c}256.0 * * * \\
(78.40)\end{array}$ & $\begin{array}{c}149.2 * * * \\
(51.84)\end{array}$ & $\begin{array}{c}345.2^{* * * *} \\
(102.4)\end{array}$ & $\begin{array}{c}149.2^{* * * *} \\
(51.84)\end{array}$ & & $\begin{array}{l}0.191 * * \\
(0.0815)\end{array}$ & $\begin{array}{c}1.085^{* * *} \\
(0.174)\end{array}$ \\
\hline d2009 & & $\begin{array}{c}143.1 * * * \\
(49.72)\end{array}$ & & $\begin{array}{c}185.2 * * * \\
(62.93)\end{array}$ & & $\begin{array}{c}-109.1 * * * \\
(40.56)\end{array}$ & & $\begin{array}{c}0.883 * * * \\
(0.169)\end{array}$ \\
\hline Constante & $\begin{array}{c}225.3^{*} \\
(121.3)\end{array}$ & $\begin{array}{c}543.6^{* * * *} \\
(204.8)\end{array}$ & $\begin{array}{c}320.9 * * \\
(149.7)\end{array}$ & $\begin{array}{l}744.9 * * \\
(318.4)\end{array}$ & $\begin{array}{c}320.9 * * \\
(149.7)\end{array}$ & $\begin{array}{c}490.3 \\
(306.2)\end{array}$ & $\begin{array}{c}2.466^{* * * *} \\
(0.573)\end{array}$ & $\begin{array}{c}-0.00105 \\
(1.648)\end{array}$ \\
\hline Observações & 593 & 593 & 428 & 428 & 428 & 428 & 576 & 576 \\
\hline $\mathrm{R}^{2}$ & 0.157 & 0.173 & 0.223 & 0.240 & 0.223 & 0.240 & 0.324 & 0.340 \\
\hline Número de id & 69 & 69 & 51 & 51 & 51 & 51 & 69 & 69 \\
\hline
\end{tabular}

Robust standard errors in parentheses

$* * * \mathrm{p}<0.01, * * \mathrm{p}<0.05, * \mathrm{p}<0.1$

Fonte: do autor. 


\subsection{2 - Análise dos Resultados}

Inicialmente, analisando-se as variáveis institucionais, os resultados demonstram que de fato as instituições importam na decisão de investimento, conforme o argumento de North (1990); Dunning (2001). Porém, o impacto das instituições não se dá de forma uníssona em todos seus domínios (AOKI, 2007). A não significância das variáveis: POLITF (h2); ECONF (h3), na quase totalidade dos modelos, expõem que os domínios econômicos e políticos não são tão importantes para a aplicação do IED, diferentemente do que ocorre com os direitos de propriedade LEGALF ( $h l$ ) existentes no domínio organizacional (AOKI, 2007).

Constata-se que em praticamente todos os modelos a variável LEGALF ( $h l$ ) é positivamente relacionada com IED, mostrando-se significativa desde $1 \%$ a $10 \%$, dependendo do modelo ${ }^{36}$. Tal fato corrobora a teoria de Foss e Foss (2005) e Kim e Mahoney (2007) sobre a importância na presença de direitos de propriedade bem definidos na decisão de investimento. Constata-se com estes resultados que é justamente a presença de direitos de propriedade assegurados e salvaguardados institucionalmente que fazem com que a renda potencial seja de fato passível de ser realizada pelo investidor detentor da posse do recurso.

Passando-se à análise das variáveis de recurso, os resultados demonstram que a Produtividade da Terra (h5) não tem impacto significativo na decisão de investimento, diferentemente do que provou a análise qualitativa. Já a variável Disponibilidade de Terras Agricultável $(h 4)$ mostrou-se significativa em quase a totalidade dos modelos ${ }^{37}$. Entretanto, diferentemente do que se era esperado, a relação entre a Disponibilidade de Terras Agricultáveis (h4) e o nível de IED é negativa. Ou seja, não é uma maior disponibilidade que atrai um maior nível de IED, mas sim o contrário. Diferentemente do que se supunha, à medida que a disponibilidade de terras agricultáveis diminui ${ }^{38}$, há um aumento em sua "raridade" (em termos da TBR), o que potencialmente levaria a um aumento de preço

\footnotetext{
${ }^{36}$ Apenas em dois dos oito modelos esta variável mostrou-se não significativa.

${ }^{37}$ Apenas em um dos oito modelos esta variável mostrou-se não significativa.

${ }^{38}$ Proporcionalmente ao total de terras presente no respectivo país.
} 
(valorização), fazendo com que a soma de aplicações requeridas para comprar uma área em um determinado país se eleve.

Tal fator pode ser comprovado, por exemplo, ao verificar-se a evolução no preço das terras observadas por Reydon e Fernandes (2012). Ao analisar-se comparativamente a evolução dos preços das terras agricultáveis entre um país em desenvolvimento (Brasil) e outro desenvolvido (EUA), é possível verificar como ao longo de uma década a valorização dos preços da terra ocorreu de forma mais acentuada no Brasil do que na nação norte-americana (vide Figura 13).

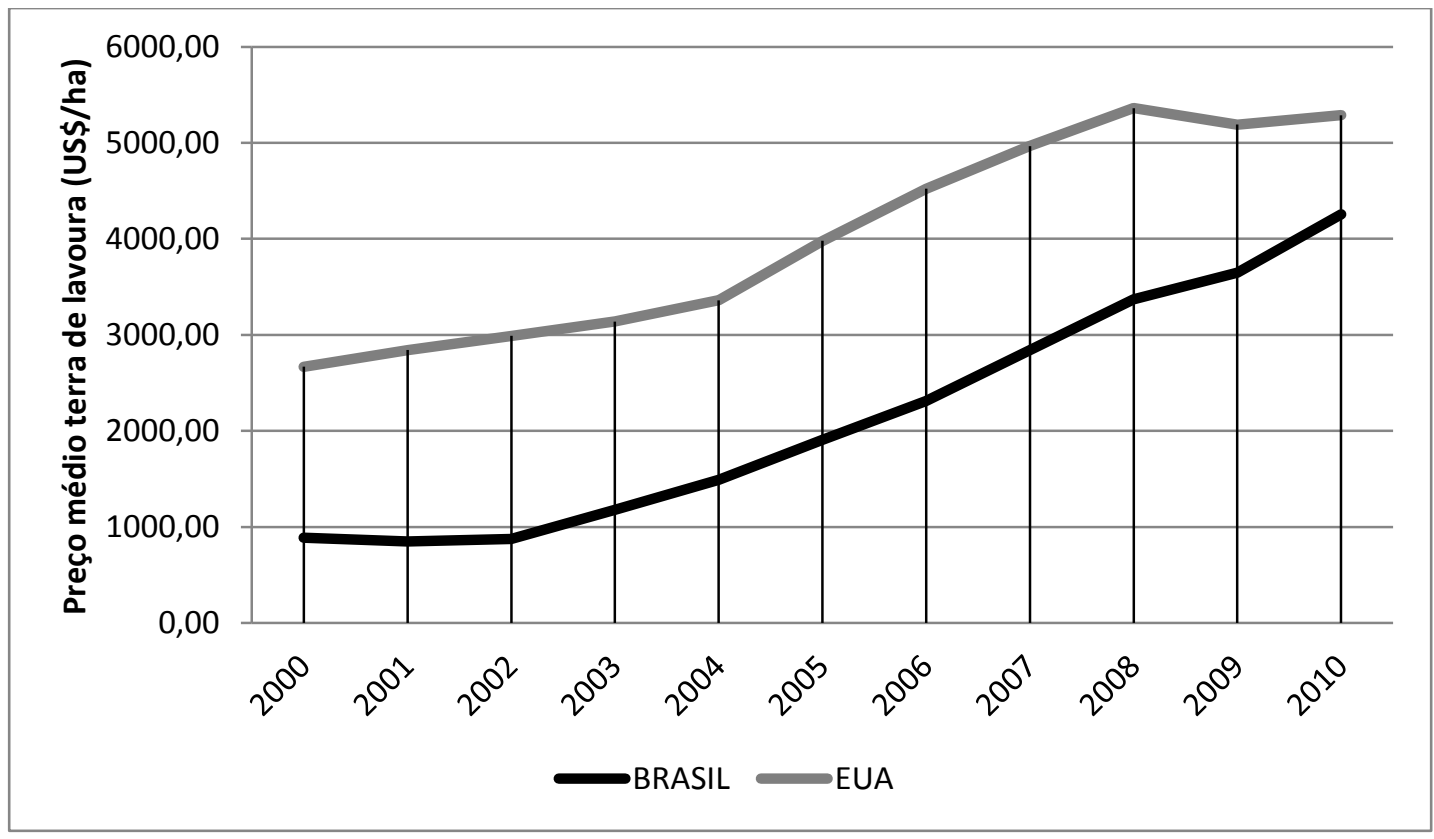

Figura 13 - Evolução Comparativa EUA/Brasil sobre o Preço da Terra Agricultável Fonte: FNP apud Reydon; Fernandez (2012). Dados trabalhados.

Sumarizando, a análise quantitativa corroborou a hipótese $(h l)$ sobre a pertinência dos direitos de propriedade - LEGALF - na atração de IED, bem como demonstrou que de fato a Disponibilidade de Terras Agricultáveis $(h 4)$ é importante na atração de IED. Contudo, diferentemente do que se supunha, é um aumento na "raridade" destas terras que gera um aumento das aplicações externas. Em outras palavras, é inversa a relação entre Disponibilidade de Terras Agricultáveis e IED, quando considerada longitudinalmente. Já as demais variáveis não se mostraram significativas como potenciais fatores de atração ao IED. 


\section{DUAS EXPERIÊNCIAS DE INVESTIMENTO EXTERNO DIRETO EM TERRAS}

A realização de estudos em profundidade tem como função apresentar com maior profundidade analítica o tema tratado, assim como permitir uma discussão mais detalhada das hipóteses teóricas levantadas e testadas no capítulo anterior. Ao se analisar as experiências de dois países - Moçambique e Brasil - que possuem ambientes institucionais e recursos bastante distintos, foi possível identificar determinantes específicos do IED nestas localidades e contrapor os achados com os resultados obtidos nas análises qualitativa e quantitativa.

\section{1 - A Experiência Moçambicana}

A análise da experiência moçambicana foi realizada com base em fontes secundárias e primárias. A partir de fontes secundárias, buscou-se delinear a história recente de Moçambique visando analisar o contexto regulatório e sua influência na dinâmica de compra de terras. As fontes primárias tiveram a finalidade de melhor compreender as regras que determinam o movimento de investimentos em terras moçambicanas. Para a coleta de dados primários, foi realizada uma visita de 12 dias ao país africano ${ }^{39}$, durante a qual foram realizadas dez entrevistas, de em média uma hora de duração, com agentes do setor público, privado, e com funcionários de organismos internacionais. Dentre as organizações entrevistadas pode-se citar: Tongaat Hulett (Indústria Açucareira), Companhia Industrial de Matola (CIM), Centro de Promoção da Agricultura (CEPAGRI), Centro de Promoção do Investimento (CPI), Centro de Formação Jurídica Judiciária (CFJJ), União Nacional dos Camponeses (UNAC), Embrapa, Programa das Nações Unidas para o Desenvolvimento (PNUD), Food and Agriculture Organization (FAO), dentre outros.

Para efeito desta pesquisa, destacam-se as informações obtidas pelas entrevistas devido ao fato de tratar-se de um fenômeno recente com poucas informações disponíveis em banco de

\footnotetext{
${ }^{39}$ A visita a Moçambique aconteceu entre 08 de outubro de 2011 e 19 de outubro de 2011.
} 
dados secundários. Para discutir a experiência moçambicana, será inicialmente abordado o ambiente institucional do país com as fontes secundárias disponíveis. A seguir são discutidas a regras dos investimentos em terras e seus impactos, a partir das informações obtidas com entrevistas com os agentes locais moçambicanos.

\subsection{1 - Ambiente Institucional em Moçambique e os Investimentos em Terras}

Moçambique é considerado um dos países mais pobres do mundo. Em 2011, no ranking do IDH (Índice de Desenvolvimento Humano) do PNUD (Programa das Nações Unidas para o Desenvolvimento), o país se classificou em $184^{\circ}$, em uma lista de 187 países avaliados, apresentado índice de $0,322 .{ }^{40}$ Ressalta-se que $74,7 \%$ da população vivem com menos de U\$1,25 por dia, a esperança de vida da população é de 48,4 anos, e a média de escolaridade no país é de 1,2 anos (PNUD, 2010, p.154).

A pobreza do país é contrastante com a riqueza de recursos naturais agrícolas existentes. De acordo com o Banco Mundial (2010), Moçambique se configura como um dos países com uma das maiores disponibilidades de terras agricultáveis não cultivadas, não protegidas e não cobertas com florestas da África subsaariana. Apesar do país representar apenas 3,25\% da área subsaariana, Moçambique detém 15\% das terras agricultáveis disponíveis no continente, o que corresponde a mais de 29 milhões de hectares (BANCO MUNDIAL, 2010).

Em termos políticos, Moçambique é um país de paz relativamente recente. Após lutas coloniais que o emanciparam da metrópole portuguesa em 1975, o país permaneceu em guerra civil até 1990, fruto da política de guerra fria, na qual a África se destacava nas estratégias militar-ideológica da URSS e dos EUA. Durante a guerra civil moçambicana se opunham dois partidos a FRELIMO (Frente de Libertação Nacional) de ideologia marxista, e a RENAMO (Resistência Nacional Moçambicana) de ideologia liberal. Após o final do conflito armado, a

${ }^{40} \mathrm{O}$ Índice de Desenvolvimento Humano é uma medida do progresso em longo prazo considerando três dimensões básicas do desenvolvimento humano: renda, educação e saúde. O índice varia de 1 a 0 , sendo o primeiro lugar do ranking ocupado pela Noruega cujo IDH é de 0,943. 
FRELIMO, partido "vitorioso", abandonou alguns traços da ideologia marxista, e promulgou a constituição moçambicana de 1990, instituindo a democratização e o multipartidarismo no país por meio de uma república presidencialista (CIA, 2011). Esta constituição de 1990 teve papel de destaque em fornecer as bases para consolidação das leis de Investimentos de 1993, de Terras de $1997^{41}$ e do Meio Ambiente de 1999. Todas determinantes para o entendimento da dinâmica de investimento externo no país.

Comparado a outros países africanos, Moçambique é considerado um país estável no âmbito político, apesar dos indícios de fraudes eleitorais ocorridos nas eleições de $2004 .{ }^{42}$ Desde 2005, quem ocupa a cadeira presidencial é Armando Emílio Guebuza (FRELIMO), que foi reeleito em 2009 para um segundo mandato, com a promessa de continuar as políticas econômicas de atração de investimento estrangeiro.

A disponibilidade de recursos naturais de Moçambique, em conjunto com a política governamental de atração de investimentos voltada ao crescimento econômico, tem intensificado o interesse de investidores internacionais em alocar seus recursos nas terras do país. Dentre os projetos de investimento estrangeiros destacam-se aqueles ligados à mineração ao agronegócio, tanto para produção de alimentos quanto bioenergia.

Segundo dados do CPI (Centro de Promoção de Investimentos), órgão que regula e aprova os projetos de investimento (interno e externos), em 2009 o setor de agronegócios e agroindústria foi responsável por aproximadamente $85 \%$ do total de Investimentos Externos Diretos (IED) recebidos, correspondendo a um montante de 1,48 bilhões de dólares. Este setor foi também responsável por $60 \%$ da geração de empregos no período (vide Tabela 6). Observa-se também que tais investimentos representam apenas $13 \%$ do total de projetos (33 projetos), o que indica a importância desses projetos em termos recursos financeiros.

\footnotetext{
${ }^{41}$ Entre as regras institucionais, a Lei de Terras ainda traz a lógica da doutrina marxista ao impedir a posse delas aos agentes privados.

${ }^{42}$ A sucessão de Joaquim Chissano em 2004, após 18 anos de presença no gabinete presidencial, levou a tensões entre os dois partidos - FRELIMO (governo) e RENAMO (oposição), por conta de fortes acusações de crime eleitoral.
} 
Tabela 6 - Investimentos aprovados por setor de jan a dez 2009

\begin{tabular}{l|lllll}
\hline Setores & $\mathbf{N}^{\mathbf{0}}$ de Proj. & IDE $(\mathbf{U} \mathbf{)}$ & $\mathbf{\%}$ & $\mathbf{N}^{\mathbf{0}}$ de Emprego & $\mathbf{\%}$ \\
\hline Agricultura e Agro-Indústrias & $\mathbf{3 3}$ & $\mathbf{1 . 4 8 8 . 5 8 7 . 0 5 1}$ & $\mathbf{8 3 , 7 8 \%}$ & $\mathbf{1 6 . 1 1 1}$ & $\mathbf{6 0 , 2 1 \%}$ \\
\hline Aquacultura e Pescas & 3 & 26.152 .500 & $1,47 \%$ & 257 & $0,96 \%$ \\
Banca e Seguradoras & 3 & 11.136 .990 & $0,63 \%$ & 185 & $0,69 \%$ \\
\hline Construções e Obras Públicas & 24 & 14.182 .075 & $0,80 \%$ & 864 & $3,23 \%$ \\
Indústria & 60 & 35.627 .750 & $2,01 \%$ & 2.666 & $9,96 \%$ \\
Recursos Minerais & 1 & 3.650 .667 & $0,21 \%$ & 47 & $0,18 \%$ \\
Transportes e Comunicações & 18 & 13.927 .500 & $0,78 \%$ & 819 & $3,06 \%$ \\
Turismo e Hotelaria & 57 & 73.972 .570 & $4,16 \%$ & 2.264 & $8,46 \%$ \\
Serviços & 51 & 109.517 .269 & $6,16 \%$ & 3.545 & $13,25 \%$ \\
\hline Total & $\mathbf{2 5 0}$ & $\mathbf{1 . 7 7 6 . 7 5 4 . 3 7 2}$ & $\mathbf{1 0 0 , 0 0 \%}$ & $\mathbf{2 6 . 7 5 8}$ & $\mathbf{1 0 0 , 0 0 \%}$ \\
\hline
\end{tabular}

Fonte: CPI (2009). Dados concedidos ao autor.

Ademais, segundo dados da UNCTAD, em dez anos (2000 a 2010) o país aumentou em 440\% o recebimento de IED, o que permite inferir que, de uma forma geral, a política moçambicana tem sido eficaz na atratividade dos investimentos externos. Entretanto, considerando a necessidade de se entender como esse processo ocorre internamente buscou-se informações in loco para melhor compreender a dinâmica que se delineia nesse novo mercado.

4.1.2 - Ambiente Institucional Moçambicano: A Visão dos Agentes Locais

Conforme se relatou anteriormente, a experiência moçambicana fora composta tanto por dados secundários quanto primários, sendo estes últimos coletados durante entrevistas com agentes locais. As entrevistas realizadas tiveram como principal objetivo entender a forma de inserção dos investidores no país. Principalmente porque, diferentemente de uma economia capitalista, as instituições moçambicanas apresentam idiossincrasias que implicam altos custos de transação.

A partir da leitura da legislação moçambicana e das entrevistas realizadas no CEPAGRI, CPI e CFJJ, foi possível construir a lógica do processo de ingresso dos investimentos estrangeiros no país. Conforme já comentado, foi relatado que em Moçambique não existe um mercado formal de terras. Devido à ideologia marxista, sob a qual foi fundado o Estado moçambicano, não existe propriedade privada. A terra é de posse do Estado, que concede aos indivíduos direito de uso e de aproveitamento (DUAT) em caráter temporário de 50 anos renováveis. 
Caso um investidor, seja nacional ou estrangeiro, tenha interesse em aplicar seus recursos na agricultura, este deverá entrar com um pedido de concessão de DUAT, e percorrer dois caminhos concomitantes para obter a aprovação do investimento e a obtenção do direito sobre a terra.

O primeiro processo - de aprovação do investimento - requer a entrada da documentação no CPI (Centro de Promoção de Investimento), que é o órgão responsável por regular e aprovar o investimento (interno e externo) em Moçambique. Esse trâmite segue o artigo 21 da Lei n. $3 / 93$ (lei de investimentos) disposto a seguir:

1. a realização, no País, de projectos de investimento elegíveis ao gozo das garantias e incentivos previstos nos termos desta lei carece de autorização de entidades governamentais competentes. (MOÇAMBIQUE, 1993)

Observa-se assim que qualquer projeto de investimento, seja ele estrangeiro ou nacional, requer aprovação do CPI, e a depender do montante e setor de atuação também é requerida a aprovação em outras instâncias governamentais.

O segundo processo - de obtenção do direito sobre a terra - está diretamente relacionado à Lei n. ${ }^{\circ} 19 / 97$ (Lei de Terras), que determina a terra como propriedade do Estado, o que impede a formação de um mercado regular e formal de terras. $\mathrm{O}$ investidor interessado em aplicar seus recursos em terras necessita uma concessão estatal de Direito de Uso e Aproveitamento da Terra (DUAT). Segundo o artigo 12 da referida lei:

O direito de uso e aproveitamento de terra é adquirido por:

a) ocupação por pessoas singulares e pelas comunidades locais, segundo as normas e práticas costumeiras no que não contrariam a Constituição;

b) ocupação por pessoas singulares nacionais que, de boa-fé, estejam a utilizar a terra há pelo menos dez anos;

c) autorização de pedido apresentado por pessoas singulares ou colectivas na forma estabelecida na presente Lei. (MOÇAMBIQUE, 1997 apud UNAC JUSTIÇA AMBIENTAL, 2011)

Além disso, de acordo com o documento "Os senhores da terra" (UNAC JUSTIÇA AMBIENTAL, 2011) os tramites de aprovação e instância governamental decisória também dependem do montante de hectares demandado pelo investidor, da seguinte forma:

Em relação à alocação de áreas, a Resolução 70/2008 estabelece que:

As aplicações para o DUAT de áreas até 1000 hectares devem ser submetidas aos Governadores Provinciais; 
As aplicações para o DUAT de áreas entre 1000 e 10000 hectares devem ser submetidas ao Ministério da Agricultura e Pescas;

As aplicações para o DUAT que vão além da jurisdição do Ministério de Agricultura e Pescas deverão ser autorizadas pelo Conselho de Ministros. (UNAC JUSTIÇA AMBIENTAL, 2011)

A Figura 14 apresenta de forma esquemática o caminho que o investidor deve percorrer para obter a aprovação dos processos de investimento e de exploração da terra em Moçambique.

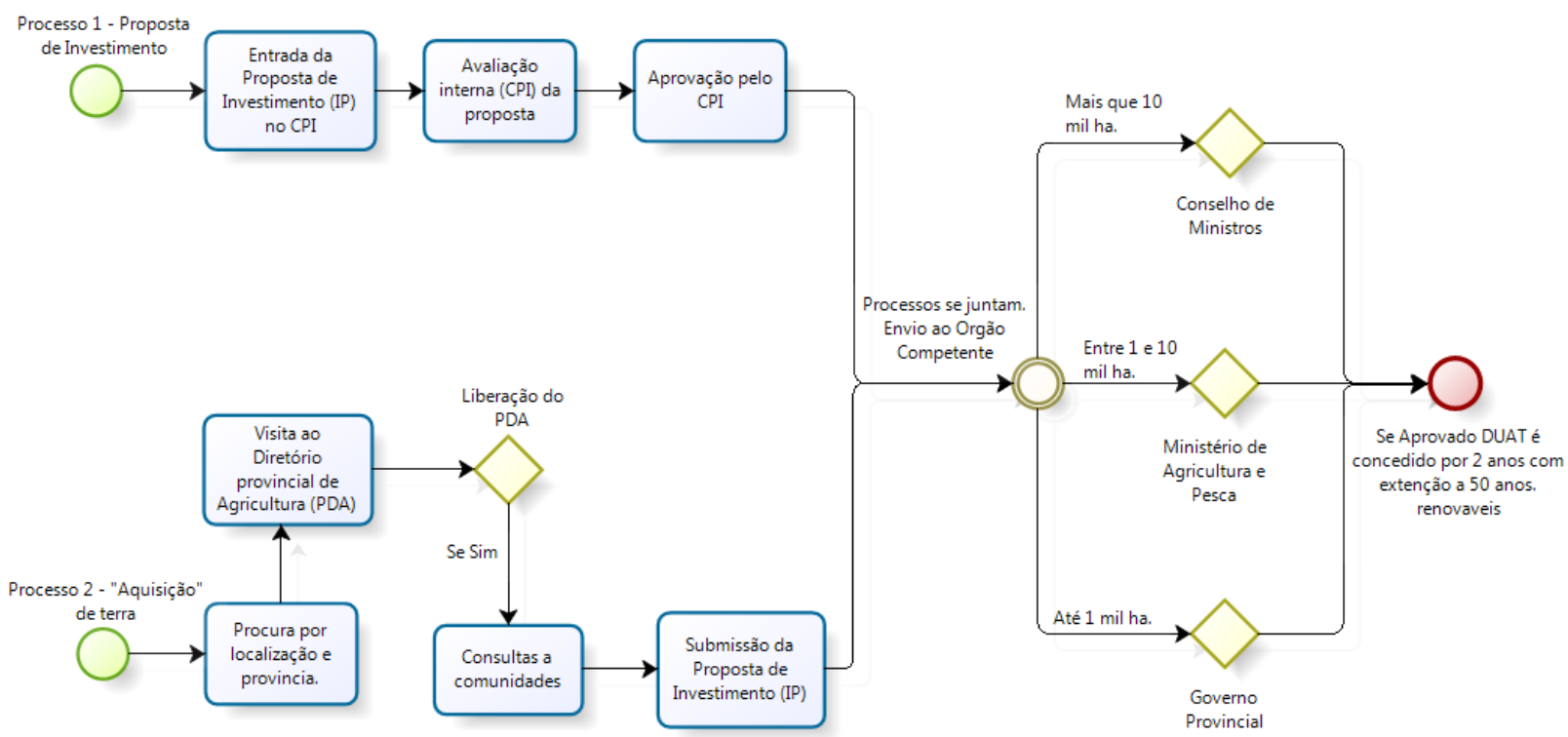

Figura 14 - Processo de aplicação de projeto e direito à terra em Moçambique Fonte: o próprio autor

Percebe-se na observação da Figura 14 que de fato existe um considerável custo de transação para a realização de um investimento em terras. Ou seja, é consideravelmente custosa e restrita a liberdade de investimentos em terras moçambicanas, apesar da determinação do governo em auxiliar os investidores neste processo. Segundo entrevistas com representantes do Centro de Formação Jurídica Judiciária:

o governo moçambicano se encontra em um dilema, pois ao mesmo tempo em que anseia o investimento externo e as possíveis divisas que este tem para oferecer, tem que garantir os direitos constitucionais aos cidadãos locais. (Maputo, 14 de outubro de $2011)^{43}$

${ }^{43}$ Entrevista realizada no dia 14 de outubro com diretor do Centro de Formação Jurídica Judiciária de Moçambique (CFJJ). 
Tal dilema é explicitado quando se considera os relatos oriundos de entrevista realizada com funcionários da agência FAO, em Moçambique. Segundo a referida instituição, diferentemente da África do Sul, onde ocorreu o Apharteid, Moçambique se caracteriza por ser um país sem vazios populacionais no interior. Logo, não existem grandes extensões de terra com baixa densidade demográfica para serem utilizadas. De acordo com dados secundários, apenas 38\% da população encontra-se em meio urbano (CIA, 2011). Realidade bem diferente, por exemplo, na África do Sul, onde $62 \%$ da população residem na área urbana e mesmo no Brasil, local em que esse valor atinge 87\% do total (CIA, 2011). Isto é, o governo defronta-se com um dilema, pois deve garantir os direitos à terra das populações rurais, mas tal direito acaba criando obstáculos aos investimentos em larga escala ansiados pelos estrangeiros e pelo próprio governo.

O presente dilema é potencializado, ao considerar-se o relato da entrevista com agentes do Programa das Nações Unidas para o Desenvolvimento (PNUD) no país. De acordo com a fala do funcionário do referido programa, não existe uma elevada taxa de urbanização em Moçambique, mesmo porque nas grandes cidades as oportunidades de emprego não são muito expressivas. Segundo dados da CIA (2011), o país tem uma taxa de urbanização de apenas $4 \%$ a.a.

Ao analisar este contexto, seria esperado inferir que há um ambiente pouco favorável ao investimento em terras, dada à inexistência de um mercado formal de terras, o baixo nível de liberdade ao investimento e a não existência de vazios demográficos em áreas agrícolas. Porém, segundo relatos das entrevistas com funcionários da CFJJ, do PNUD e da FAO, fatores como: baixa escolaridade, pouco conhecimento jurídico e baixa representatividade da população junto ao governo; aliados à influência política e econômica dos investidores externos na máquina pública; faz com que haja uma 'flexibilização' nos processos burocráticos para obtenção do DUAT por gestores governamentais.

Para auxiliar os investidores, o CEPAGRI, que se constitui em um braço do Ministério da Agricultura do país, funciona como uma consultoria de apoio aos investidores estrangeiros para tomarem ciência das regras de aplicação dos recursos, de forma a dar-lhes apoio durante o processo. Segundo entrevista realizada com membros da organização: 
o papel fundamental do CEPAGRI é divulgar as oportunidades locais a fim de atrair investidores, funcionando como uma consultoria de apoio ao investidor nos trâmites de pedido e processo de concessão do DUAT (Maputo, 18 de outubro de 2011). ${ }^{44}$

Vale destacar que o CEPAGRI tem uma dupla função: atuar como uma consultoria de apoio ao investidor e fiscalizar/monitorar a implantação dos projetos, visando evitar conflitos com as populações locais. Ressalta-se que essa dupla atribuição pode levar a conflitos de agência, dado que, ao mesmo tempo, aquele que recebe recursos para auxiliar a realização dos projetos, monitora a implantação destes para que não se firam os interesses das comunidades locais. Muitas vezes, conforme informado pelo representante da CFJJ:

[...] não há sequer a formalização de um contrato entre investidores e comunidades (conforme exigiria a lei), propiciando arbitrariedade de obrigações entre as partes envolvidas. (Maputo, 14 de outubro de 2011) ${ }^{45}$

Em suma, a atratividade do aporte financeiro trazido pelos investidores é tão grande para o governo moçambicano que este "facilita" e, por vezes, até negligencia as obrigatoriedades institucionais, com o intuito de garantir a entrada de capital.

Soma-se a isto o fato de que, à medida que aumenta o montante de terra a ser pretendido pelo investidor, torna-se necessária a aprovação de instâncias governamentais superiores, implicando que, quanto maior for o projeto de investimento, mais a comunidade envolvida ('principal') estará afastada das decisões governamentais ('agente'), aumentando-se potencialmente o risco de oportunismo (seleção adversa e risco moral) nas decisões e seleção dos projetos de investimento, e aumentando ainda mais o risco de 'captura do estado' (STIGLER, 1971) pelos estrangeiros nos processos de investimentos em terra.

Por fim, a corrupção e as ligações com o governo passam a ser fundamentais como garantias de acesso aos recursos agrícolas estratégicos existentes no país, bem como na garantia dos direitos de propriedade após a concessão do DUAT. Segundo coordenador da FAO: “a melhor

\footnotetext{
${ }^{44}$ Entrevista realizada no dia 18 de outubro com funcionário do Centro de Promoção da Agricultura de Moçambique (CEPAGRI).

${ }^{45}$ Entrevista realizada no dia 14 de outubro com diretor do Centro de Formação Jurídica Judiciária de Moçambique (CFJJ).
} 
forma de garantir salvaguardas ao investimento realizado é tendo relações estreitas com o governo ou alguém lá dentro.” (Maputo, 18 de outubro de 2011) ${ }^{46}$

\subsection{3 - Considerações Finais sobre a Experiência Moçambicana}

Conforme observado, o ambiente institucional moçambicano tem contundente impacto no padrão do IED recebido pelo país. Sendo Moçambique um país com baixo índice de desenvolvimento, a procura por investimentos externos pelo Estado é vista como uma forma 'eficaz' de elevar rapidamente o produto interno bruto.

Considerando-se que, apesar dos altos custos de transação, as regras de ingresso ao país podem se tornar mais "flexíveis" aos grandes investidores, estas assimetrias entre os agentes implicam elevados lucros para aqueles que conseguem acessar com privilégios o poder público. Esse resultado em consonância com a literatura econômica (LIPPMAN, RUMELT, 2003; SAES, 1997; STIGLER, 1971) mostra que, ao deter elevado poder de barganha, um investidor externo pode corromper (h2) e 'capturar' as instituições públicas locais para obter vantagens nos processos de investimentos, concessão e manutenção de DUAT's.

As evidencias moçambicanas também endossam a hipótese sobre direitos de propriedade $(h l)$. Segundo relatos da FAO e CEPAGRI, após passar por todo o processo de concessão do DUAT, dificilmente este é revertido; ademais, o investidor tem a opção de renovação no período de exploração por mais 50 anos. Em outras palavras, o Estado moçambicano acaba garantindo os direitos de propriedade legais ao investidor, desde que este esteja alinhado com o governo.

Esses achados também proporcionam uma explicação teórica para os resultados das análises qualitativa e quantitativa relacionada à liberdade de investimento ( $h 3)$. Observou-se que a não existência de um mercado formal de terras em Moçambique não coíbe o fluxo de projetos de

\footnotetext{
${ }^{46}$ Entrevista realizada no dia 18 de outubro com coordenador da FAO em de Moçambique.
} 
investimento (refutando $h 3$ ). A explicação pode estar ligada ao potencial de maior lucro, seja decorrente do maior risco do investimento, seja determinado pela maior capacidade de captura das firmas da regra institucional.

No que se refere aos atributos da terra, vistos como recursos estratégicos, a experiência de Moçambique não permite inferir resultados sobre a Disponibilidade de Terras Agricultáveis, porque não há dados sobre preços (dado que não há um mercado formal), apesar de saber-se que há uma considerável disponibilidade de terras no país $(h 4)$. Também com relação à produtividade ( $h 5$ ), não é possível concluir causalidade na relação com os estudos que foram realizados em Moçambique. No entanto, devido ao ainda precário uso da terra, com técnicas agrícolas rudimentares pode-se inferir que possivelmente a hipótese seja corroborada.

Por fim, infere-se que a experiência moçambicana permite vislumbrar principalmente as hipóteses institucionais levantadas no capítulo 2 , de forma a verificar mais profundamente a relação entre as hipóteses e o padrão de recebimentos de IED. Agora, proceder-se-á a análise da experiência brasileira.

\section{2 - A Experiência Brasileira}

Assim como em Moçambique e em diversos países da África Sub Saariana, também na América Latina tem se intensificado o movimento de investimentos em terras. Com a finalidade de traçar um paralelo entre estas duas localidades, e comparar como diferentes ambientes institucionais lidam com as perspectiva de investimentos estrangeiros em terras, o Brasil foi selecionado como a segunda experiência a ser estudada nesta pesquisa.

Semelhantemente à moçambicana, na experiência brasileira fez-se uso de fontes secundárias e primárias em sua elaboração. Foram coletados dados de pesquisas realizadas tanto no Brasil quanto no exterior, a igualmente realizaram-se entrevistas com diversos agentes envolvidos com a temática, desde acadêmicos, empresários até pessoas ligadas ao parlamento brasileiro.

A experiência brasileira inicia-se com um panorama dos investimentos em terras, evidenciando dados sobre suas tendências no país. Posteriormente, estuda-se a constituição do 
regramento institucional brasileiro em uma breve perspectiva histórico-jurídica. Por fim, relaciona-se este regramento com as aplicações que vem ocorrendo fundamentando-se com os relatos obtidos durante as entrevistas.

\subsection{1 - Investimento Estrangeiro em Terras Brasileiras}

Assim como outros países, o Brasil vem sendo noticiado como um dos principais destinos dos investimentos agrícolas (CHINA COMPRA TERRAS NO BRASIL, 2010). Devido ao crescimento das especulações sobre investimentos externos em terras no país, o Sistema Nacional de Cadastro Rural (SNRC) e Instituto Nacional de Colonização e Reforma Agrária (INCRA), órgãos responsáveis pelo cadastro de registros de imóveis rurais, realizaram em 2009 um levantamento acerca dos registros de terras em mãos estrangeiras, presentes no território nacional ${ }^{47}$. De acordo com o levantamento, até 2008, existiam 34.632 registros de imóveis rurais em mãos de estrangeiros, representando aproximadamente quatro milhões de hectares (PRETTO, 2009).

Segundo o relatório, a maior concentração de imóveis em mãos estrangeiras se encontra no centro-oeste brasileiro, seguido pelo sudeste e com o nordeste em terceiro (PRETTO, 2009). Destaca-se que estados de grande produção agrícola são os “campeões" em registros em mãos não-nacionais, por exemplo: Mato Grosso (aproximadamente 700 mil hectares em mãos estrangeiras); Mato Grosso do Sul (em torno de 450 mil hectares) e São Paulo (com quase 400 mil hectares). Nota-se também que a evolução dos registros ocorreu de forma mais contundente a partir da década de 1970 , já sob a vigência da lei $5709 / 71^{48}$ a ser detalhada mais adiante (vide Figura 15).

\footnotetext{
${ }^{47}$ Projeto de Cooperação Técnica (PCT) "Apoio às Políticas e à Participação Social no Desenvolvimento Rural" - PCT Instituto Interamericano de Cooperação para a Agricultura (IICA) / Núcleo de Estudos Agrários e Desenvolvimento Rural (NEAD) (PRETTO, 2009).

${ }^{48}$ Observa-se, pelos dados do INCRA, queda nas últimas duas décadas tanto do número de registros como de áreas adquirida por estrangeiros. Porém, tendo em vista o crescimento das exigências e os impedimentos institucionais ao ingresso dos estrangeiros, há razões para acreditar que esses dados não refletem a realidade do movimento de investimentos em terra.
} 


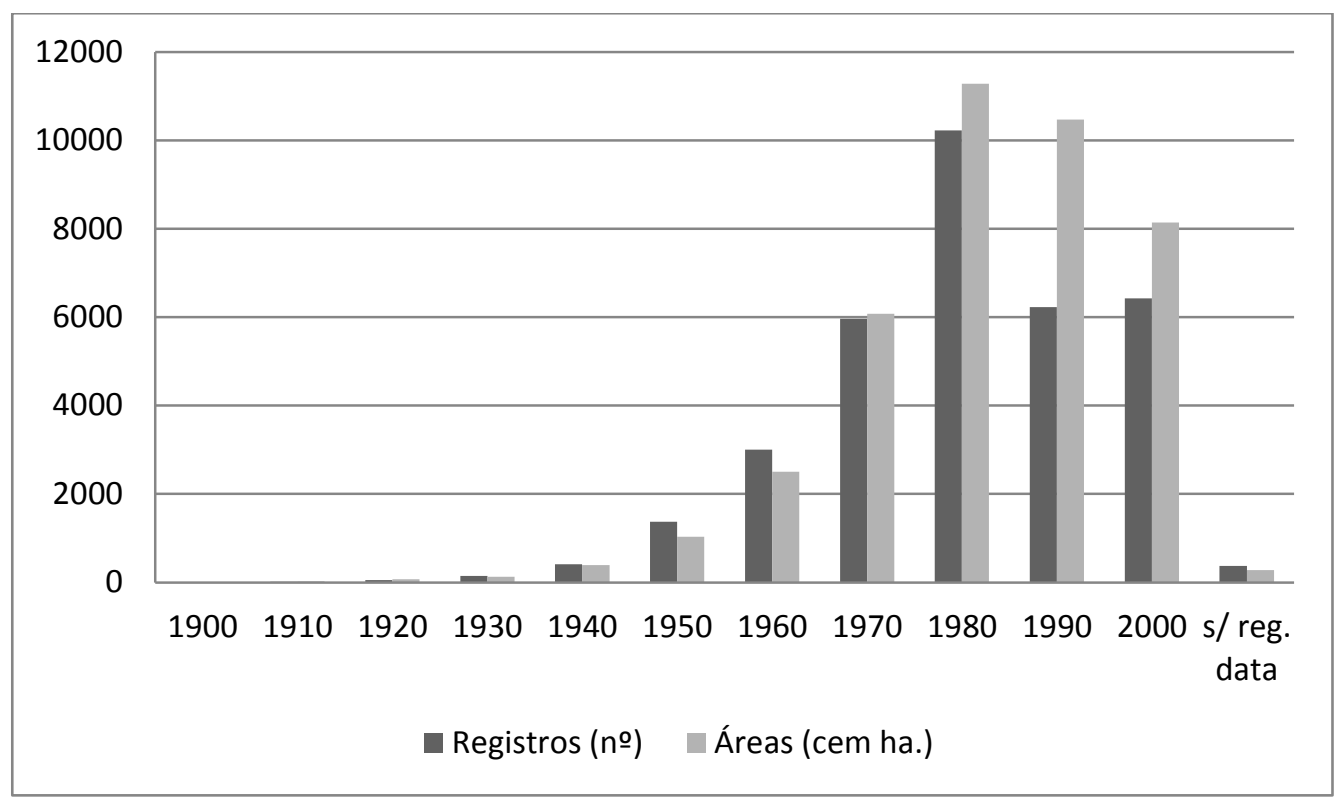

Figura 15 - Evolução dos Registros e Áreas em Mãos de Estrangeiros

Fonte: INCRA, Apuração especial apud Pretto (2009)

Observando tais números tem-se a impressão que os estrangeiros detêm grandes extensões de terra no país, contudo analisando comparativamente, estes registros representam apenas 1,2\% do total de registros existentes e apenas $0,22 \%$ do total de áreas registradas no país (PRETTO, 2009). Tais números demonstram que a posse de terras por estrangeiros no Brasil ainda é relativamente pequena quando considerada no total de áreas e registros existentes. Contudo, estima-se que tais números tenderiam a mudar com o atual movimento de compra de terras.

De acordo com o estudo Highquest Partners apud Reydon, Fernandes (2012), o potencial agrícola do Brasil faz com que o país seja alvo de aproximadamente: "1/3 dos investimentos globais em terras" (REYDON, FERNANDES, 2012, p.6). Dados do Banco Central do Brasil (2012) apontam que entre 2001 e 2009 o setor de agricultura pecuária e extrativismo mineral recebeu mais de 30 milhões de dólares, destaque para o ano de 2008 com quase 13 milhões em investimento (vide Tabela 7). ${ }^{49}$ Ademais, segundo a mesma instituição serviços relacionados as "atividades imobiliárias" receberam quase 4\% do IED realizado no período totalizando U\$1,7 bilhões.

\footnotetext{
${ }^{49}$ Nesse ano, boa parte deste investimento ocorreu em setores de extração mineral segundo BACEN.
} 
Tabela 7 - Fluxo de Investimentos Externos no Brasil por Setor (USD Milhões)

\begin{tabular}{llllllllll}
\hline $\begin{array}{l}\text { Atividade } \\
\text { Econômica }\end{array}$ & 2001 & 2002 & 2003 & 2004 & 2005 & 2006 & 2007 & 2008 & 2009 \\
\hline $\begin{array}{l}\text { Agricultura, } \\
\text { pecuária e extrativa } \\
\text { mineral }\end{array}$ & $1.493,5$ & 637,8 & $1.487,0$ & $1.072,8$ & $2.194,3$ & $1.363,1$ & $4.982,0$ & 12.995, & $4.474,2$ \\
Indústria & $7.000,9$ & $7.555,3$ & $4.506,0$ & 10.707, & $6.402,8$ & $8.743,7$ & 12.166, & 14.012, & 11.924, \\
Serviços & 12.547, & 10.585, & $6.909,3$ & $8.484,7$ & 12.924, & 12.124, & 16.556, & 16.877, & 14.044, \\
Total & 21.041, & 18.778, & 12.902, & 20.265, & 21.521, & 22.231, & 33.704, & 43.886, & 30.443, \\
\hline
\end{tabular}

Devido a esta intensificação dos investimentos estrangeiros em terras brasileiras, o governo vem continuadamente tentando frear este movimento. ${ }^{50}$ Entretanto, para entender a relação deste movimento com as esferas governamentais e com o ambiente institucional, é necessário detalhar a estrutura do regramento institucional brasileiro sobre a posse de terra por estrangeiros, para por fim verificar como se configura a situação hodierna da questão nas esferas político-jurídicas.

\subsection{2 - Ambiente Institucional Brasileiro no Tangente a Terras}

A questão fundiária no Brasil não é uma temática simples, sua origem complexa advém do período colonial, com a promulgação da lei de terras de 1850 , e vem se intensificando ao longo do tempo, principalmente em decorrência das sucessivas tentativas governamentais de buscarem uma solução efetiva para a regulação, gestão, fiscalização e tributação da terra por meio de um sistema fundiário nacional eficiente (REYDON, CORNÉLIO, 2006; REYDON, FERNANDES, 2012; WILKINSON, REYDON, SABBATO, 2010).

A constante tentativa de regulação evoluiu a partir da lei de terras, com o estabelecimento do registro cartorial em 1864 e do registro público de terras $1900^{51}$, que buscavam documentar

\footnotetext{
${ }^{50}$ Nota-se aqui uma importante diferença entre o Brasil e Moçambique no que se refere ao movimento de aplicações estrangeiras. Percebe-se que há uma resistência muito maior aos investimentos por parte do governo brasileiro do que pelo moçambicano.

${ }^{51}$ República Velha.
} 
formalmente a posse das terras nacionais, posteriormente passando pelo estabelecimento do Instituto Brasileiro de Reforma Agrária (IBRA) em $1964^{52}$, que se tornou Instituto Nacional de Colonização e Reforma Agrária (INCRA), órgão que teria a tutela do cadastro de imóveis rurais, sendo responsável pela gestão das informações sobre áreas e registros, até chegar à elaboração da lei 6746/79 53 , na qual se estabeleciam os critérios de tributação, de acordo com tamanho da propriedade e o número de módulos fiscais ${ }^{54}$. (REYDON, CORNÉLIO, 2006; REYDON, FERNANDES, 2012; WILKINSON, REYDON, SABBATO, 2010).

Mesmo com estas diversas tentativas de regulação fundiária, até hoje o cadastro de imóveis rurais encontra-se falho e pouco informativo. Muito em decorrência da falta de um registro único e interligado capaz de articular as informações presentes nos cartórios de registro de imóveis, no INCRA, nos institutos estaduais de terras, dentre outras instituições (REYDON, CORNÉLIO, 2006; REYDON, FERNANDES, 2012; WILKINSON, REYDON, SABBATO, 2010).

No entanto, foi com a lei 5709/71 e o artigo ${ }^{\circ} 171$ da constituição de 1998 que o tema da posse de terras por estrangeiros passou a ser abordado na regulação fundiária, sendo estas duas normas as bases para a situação contemporânea do tema em questão.

Em 1971, durante o governo Médici, institucionaliza-se a lei 5709/71, que regula diretamente a aquisição de terras por estrangeiros. Segundo a Lei 5709/71 institui-se que:

Art. $3^{\circ}$ - A aquisição de imóvel rural por pessoa física estrangeira não poderá exceder a 50 (cinquenta) módulos de exploração indefinida, em área contínua ou descontínua.

\footnotetext{
${ }^{52}$ Governo Castello Branco.

${ }^{53}$ Governo Figueiredo.

${ }^{54}$ De acordo com o parágrafo segundo do artigo $50^{\circ}$ da Lei 6746/79:

$\S 2^{\circ} \mathrm{O}$ módulo fiscal de cada Município, expresso em hectares, será determinado levando-se em conta os seguintes fatores:

a) o tipo de exploração predominante no Município:

I - hortifrutigranjeira; II - cultura permanente; III - cultura temporária; IV - pecuária; V - florestal;

b) a renda obtida no tipo de exploração predominante;

c) outras explorações existentes no Município que, embora não predominantes, sejam expressivas em função da renda ou da área utilizada;

d) o conceito de "propriedade familiar", definido no item II do artigo $4^{\circ}$ desta Lei. (BRASIL, 1979)
} 
Art. $5^{\circ}$ - As pessoas jurídicas estrangeiras referidas no art. $1^{\circ}$ desta Lei só poderão adquirir imóveis rurais destinados à implantação de projetos agrícolas, pecuários, industriais, ou de colonização, vinculados aos seus objetivos estatutários.

Art. 12 - A soma das áreas rurais pertencentes a pessoas estrangeiras, físicas ou jurídicas, não poderá ultrapassar a um quarto da superfície dos Municípios onde se situem, comprovada por certidão do Registro de Imóveis, com base no livro auxiliar de que trata o art. 10.

$\S 1^{\circ}$ - As pessoas da mesma nacionalidade não poderão ser proprietárias, em cada Município, de mais de $40 \%$ (quarenta por cento) do limite fixado neste artigo. (BRASIL, 1971)

No entanto, com o processo de redemocratização e a promulgação da constituição de 1988 durante o governo Sarney, uma nova distinção é criada para tratar questões relativas ao investimento estrangeiro. Segundo Wilkinson et al (2010), o artigo $\mathrm{n}^{\circ} 171$ da constituição estabelece as distinções entre: 'empresas brasileiras', 'empresas brasileiras de capital nacional', e por negação 'empresas não brasileiras'; diferenciando assim o que seria um investidor interno de um externo, segundo a pessoa jurídica. De acordo com o Artigo 171:

Art. 171 - São consideradas:

I - empresa brasileira a constituída sob as leis brasileiras e que tenha sua sede e administração no País;

II - empresa brasileira de capital nacional aquela cujo controle efetivo esteja em caráter permanente sob a titularidade direta ou indireta de pessoas físicas domiciliadas e residentes no País ou de entidades de direito público interno, entendendo-se por controle efetivo da empresa a titularidade da maioria de seu capital votante e o exercício, de fato e de direito, do poder decisório para gerir suas atividades. (BRASIL, 1988)

Percebe-se que até aquele momento toda a legislação se alinhava com uma concepção de manutenção da soberania nacional e proteção do interesse interno frente aos estrangeiros. Mesmo com a passagem do regime militar para o democrático esta ideia protecionista se mantém no ordenamento jurídico.

Apenas em 1995, já sob a presidência de Fernando Henrique Cardoso, que são promulgadas as emenda constitucionais $\mathrm{n}^{\circ} 6$ e 35, as quais revogam o artigo 171 da constituição (WILKINSON, REYDON, SABBATO, 2010). Segundo Wilkinson et al (2010) e Reydon e Fernandes (2012), ao revogar-se o artigo 171, o governo brasileiro procurou impedir a proteção das empresas nacionais frente às estrangeiras, agindo em linha com a ideologia neoliberal. Permite-se, assim, à pessoa jurídica externa, uma maior liberdade de investimentos no mercado brasileiro em diversos setores. 
Não obstante, a posterior entrada do governo Lula, em 2003, realiza uma contenção nas políticas liberalizantes do governo precedente. Aumenta-se neste período a ingerência do governo na economia, tanto diretamente, como nas obras do Programa de Aceleração do Crescimento e estruturação de programas de auxílio social (Bolsa Família), quanto indiretamente, pelo financiamento e participação acionária de organizações e fundos públicos (BNDES/Previ) em empresas privadas nacionais (LAZZARINI, 2008).

É neste ambiente influenciado pelo movimento de investimentos estrangeiros em terras que se estrutura um processo político-jurídico para a 'revitalização' da lei 5709/71, a fim de 'proteger' as terras brasileiras frente a uma possível avalanche de capitais externos no setor agrícola. Desta forma, em 2007, após uma reunião governamental na Casa Civil, 'estimulouse' a Advocacia Geral da União (AGU) a promulgar um novo parecer impondo maiores limites à entrada de capital estrangeiro no mercado de terras (CAMARA DOS DEPUTADOS, 2012; REYDON, FERNANDES, 2012; WILKINSON, REYDON, SABBATO, 2010), fato que culminou na publicação, pela AGU, do parecer CGU/AGU n n 01/2008-RVJ / AGU LA$01 / 2010^{55}$, o qual aborda a questão das 'aquisições de terras por estrangeiros', reforçando a lei 5709/71, de modo a reendossar as limitações de aquisição ou aplicações de recursos em terras por parte de não-nacionais (BRASIL, 2010).

\subsection{3 - Desdobramentos Atuais da Temática}

Por meio da análise histórica institucional acima exposta, percebe-se que o regramento jurídico brasileiro que trata de investimentos estrangeiros em terras não sofreu mudanças propriamente ditas. Tal fato é corroborado pelos relatos colhidos com o especialista em direito agrário e membro do Grupo de Estudos Agrários (GEA-FD/FEA - USP), Samuel Luiz Araújo ${ }^{56}$. Segundo o jurista, não houve mudança na legislação. O que houve foi um parecer da AGU (BRASIL, 2010) visando conter a entrada destes investimentos; no entanto, a lei que rege este tipo de investimento (Lei 5709/71) segue inalterada.

\footnotetext{
${ }^{55}$ Publicado em agosto de 2010.

${ }^{56}$ Entrevista realizada com dr. Samuel Luiz Araújo em 15 de setembro de 2011.
} 
De acordo com a entrevista realizada com o presidente da Frente Parlamentar da Agropecuária, deputado federal Homero Pereira (PSD-MT), tal 'reforço' na aplicação da lei 5709/71: "estaria ligado às preocupações com a garantia da soberania nacional e de questões ideológicas do próprio governo." (09 de janeiro de 2013) ${ }^{57}$

O deputado reprova a medida do governo. Para ele, a permissão no investimento estrangeiro em terras, de forma associada ao capital nacional, possibilitaria avanços na produção agropecuária brasileira $^{58}$. No texto que consta ao relatório apresentado pelo deputado à Comissão de Agricultura, Pecuária, Abastecimento e Desenvolvimento Rural; e aprovado em 12 de setembro de 2012, pode-se observar a seguinte argumentação:

O país [Brasil] conta com terra, tecnologia, capacidade empreendedora e, muito importante, grande disponibilidade de água. Contamos também com um quadro de estabilidade institucional fundamental para garantir os investimentos. $\mathrm{O}$ mundo conta com nosso país para isso. Mas nos falta o capital para investir nesse aumento de produção.(CÂMARA DOS DEPUTADOS, 2012,s/p.)

No relatório são evidenciados diversos casos em que o investimento estrangeiro seria fundamental para o bom funcionamento do agronegócio brasileiro. Como argumentos são citados os seguintes fatores: maior financiamento para as lavouras, aumento do poder de negociação entre proprietários com tradings ou bancos estrangeiros, nos quais a terra funciona como colateral à concessão de empréstimos ou fornecimento de insumos; o estabelecimento de investimentos em agroindústrias silvícolas, ou sucroalcooleiras, que requerem parte da produção verticalizada pela própria empresa; dentre outros.

A possibilidade de aplicação do dispositivo legal definido pela AGU em agosto de 2010 é também contestada no relatório. Devido à instabilidade jurídica decorrente das alterações na interpretação/ênfase da lei sobre investimentos externos, o relatório deixa clara a mensagem que: "[...] a insegurança jurídica, enquanto perdura o Parecer AGU LA-01/2010, está gerando um atraso em investimentos que certamente estão migrando para outros países." (CÂMARA DOS DEPUTADOS, 2012, s/p.)

\footnotetext{
${ }^{57}$ Entrevista com Deputado Federal Homero Pereira (PSD-MT) também presidente da Frente Parlamentar da Agropecuária. Realizada por Skype® no dia 09 de janeiro de 2013.

${ }^{58}$ Entrevista realizada por Skype $®$ no dia 09 de janeiro de 2013.
} 
O relatório conclui com a constatação de que: "É impraticável exigir aprovação prévia de projetos de investimentos." (CÂMARA DOS DEPUTADOS, 2012, s/p.), devido à precária estrutura de registros com que contam os cartórios nacionais de registro rural e à potencial aversão que esta exigência prévia geraria no investidor externo, em sua decisão de aplicação.

Por fim, vale destacar que atualmente (2013), a questão legal continua inalterada. Segundo o próprio deputado Homero, apesar da cobrança política realizada pelo deputado e pela bancada ruralista no parlamento nacional: "O governo não tem se manifestado sobre o tema." (09 de janeiro de 2013) ${ }^{59}$, aumentando ainda mais, a situação de incerteza jurídica e por consequência afugentando ainda mais investidores potenciais.

\subsection{4 - Considerações Finais da Experiência Brasileira}

Assim como na experiência moçambicana, o ambiente institucional brasileiro também tem um impacto contundente no padrão dos investimentos externos no mercado de terras. Fundamentalmente embasada nas obras de Reydon e Cornelio (2006); Wilkinson et al (2010); Reydon e Fernandes (2012), verificou-se que a falta de um cadastro único e eficiente sobre mercado de terras, gera um verdadeiro imbróglio fundiário, no qual não se sabe ao certo o número exato de áreas registradas, onde estes registros estão e muito menos abre a possibilidade para se verificar as transações que ocorrem nos diversos cartórios de registro de imóveis espalhados pelo Brasil.

Esta 'confusão' fundiária se soma a um ambiente jurídico relativamente incerto. Em decorrência das instabilidades na interpretação da lei brasileira sobre investimentos estrangeiros em terras, gera-se um potencial risco de evasão de investimentos e perda de oportunidades de negócios caros à produção agrícola brasileira.

\footnotetext{
${ }^{59}$ Entrevista com Deputado Federal Homero Pereira (PSD-MT) também presidente da Frente Parlamentar da Agropecuária. Realizada por Skype® no dia 09 de janeiro de 2013.
} 
A comparação entre a experiência moçambicana e brasileira permite observar que assim como no país africano, o parecer da AGU/2010, por requerer aprovação prévia aos projetos de investimento pelos órgãos governamentais competentes, potencialmente pode incorrer em dois efeitos de segunda ordem, igualmente vividos em Moçambique:

1. Afugentar investidores produtivos interessados em realizar suas aplicações no Brasil; e

2. Realizar uma "seleção adversa" atraindo investimentos especulativos e que venham a corromper órgãos públicos nacionais em seu favor.

Por meio das evidências expostas na experiência brasileira, podem-se inferir algumas relações com as hipóteses deste trabalho. No que se refere às hipóteses institucionais, as evidências apresentadas ressaltam que o parecer da AGU/2010 aumentou o ambiente de incerteza jurídica com relação às aquisições de terras por estrangeiros no Brasil, potencialmente atuando como um fator de repulsão aos olhos dos investidores estrangeiros, por não lhes garantir, de forma "estável", salvaguardas a seus direitos de propriedade $(h l)$.

A análise da experiência brasileira não permite realizar inferências sobre a influência da corrupção na atração de IED $(h 2)^{60}$. Embora estima-se que a instabilidade na interpretação da Lei 5709/71 gere uma "brecha legal” capaz de incentivar investidores externos a por meio do ‘jeitinho’"61 ou pela utilização de pessoas físicas locais ("laranjas”) dinamizar o processo econômico-burocrático existente (ALSTON, EGGERTSSON, NORTH, 1996). Entretanto, tais conclusões apenas poderiam ser categoricamente inferidas com um estudo em maior profundidade.

No que tange à liberdade de investimentos (h3), apesar do parecer da AGU/2010 e das recorrentes alternâncias de interpretações da Lei 5709/71 supracitadas, a associação (lícita ou ilícita) entre o capital externo com pessoas jurídicas nacionais, ou a utilização de pessoas

\footnotetext{
${ }^{60}$ Vale destacar que não se quer dizer com isso que no Brasil haja mais ou menos corrupção que em Moçambique, experiência tratada na sessão 4.1.

${ }^{61}$ O capítulo 3 do livro Alston, Eggertsson, North (1996) intitulado: Public institutions and private transactions: a comparative analysis of the legal and regulatory environment for business transaction in Brazil and Chile, escrito por Andrew Stone, Brian Levy, e Ricardo Paredes; evidencia como o 'jeitinho' termo consagrado aqui no Brasil para expressar a "pequena corrupção" acaba por dinamizar o processo burocrático para abrir e gerir uma empresa de forma que empresas semelhantes no Brasil e no Chile (país extremamente liberal) conseguem ter um resultado semelhante apesar das grandes burocracias existentes no Brasil.
} 
físicas nacionais ('laranjas ${ }^{, 62}$ ) para a titulação da propriedade parecem ser formas de "flexibilizar" a entrada de investimentos no Brasil. Em outras palavras, o investidor encontra meios para realizar o investimento, caso de fato o deseje, fator este que reforça a não significância de (h3) na decisão de investimento. Não obstante, vale destacar que não há comprovações empíricas suficientes neste caso para realizar tal afirmação.

No que se refere às hipóteses de recursos estratégicos, seja a disponibilidade $(h 4)$ ou a produtividade (h5), o Brasil mostra-se com um grande potencial, principalmente com relação à hipótese (h4), já que detém cerca de $30 \%$ das terras agricultáveis disponível na América Latina e Caribe (BANCO MUNDIAL, 2010). Porém, assim como na experiência moçambicana, a avaliação do Brasil não permite inferir relações entre as hipóteses de recursos com uma maior ou menor atração de IED.

Por fim, pode-se afirmar que a experiência brasileira permite sustentar a hipótese teórica sobre a importância dos direitos de propriedade na atração de IED $(h l)$. No entanto, dada a atualidade do tema e as posições contrárias evidenciadas entre governo e membros do legislativo, a questão dos investimentos externos em terra ainda se encontra longe de uma resolução clara e definitiva.

${ }^{62}$ Termo utilizado para expressar intermediários em operações irregulares ou fraudulentas. No presente caso, refere-se a pessoas que, apesar de ter a posse legal da terra, apenas representam um terceiro que realmente tem direito de decisão sobre o negócio. 


\section{CONSIDERAÇÕES FINAIS}

Neste último capítulo serão apresentadas as principais conclusões do trabalho. Inicialmente o capítulo retomará a questão de pesquisa do estudo, bem como as teorias que o embasaram, e as hipóteses decorrentes destas. Na sequencia, serão relatados os resultados de cada uma das análises (qualitativa, quantitativa, e estudos em profundidade), a fim de confrontar os resultados obtidos nas análises realizadas: suas diferenças e similaridades e as possíveis inferências advindas destas. Por fim, serão expostas as limitações e sugestões para estudos futuros sobre o presente tema.

O aumento populacional que o mundo passará em um futuro próximo; a crescente preocupação com a segurança alimentar das populações; as constrições ambientais decorrentes da ação antrópica na natureza; dentre outras razões; vêm induzindo um fluxo de investimentos por parte de diversos agentes (empresas, Estados e fundos de pensão) em direção a países em desenvolvimento. Com o intuito de garantir acesso a terras agricultáveis potencialmente produtoras de bens alimentícios e bioenergéticos (BANCO MUNDIAL, 2000; FAO, 2012a; 2012b), estes agentes vêm formando um fenômeno de investimentos externos diretos, que ainda não se mostra com nítidos contornos. Desta maneira, o presente estudo teve como principal motivação, ainda que de forma modesta, clarificar este novo fenômeno, respondendo à seguinte questão:

\section{Quais os determinantes do investimento externo direto em terras nos países em desenvolvimento?}

Para tanto, a fundamentação teórica do presente trabalho se deu sobre duas teorias principais: a Nova Economia Institucional (NEI) e a Teoria Baseada em Recursos (TBR). A NEI revela que o ambiente institucional e as 'regras do jogo' importam e são determinantes no desempenho econômico (NORTH, 1990). Conquanto, este ambiente é dividido e influenciado por diferentes domínios: político, social, organizacional (legal) e econômico (AOKI, 2007). Sendo cada um destes responsáveis pelo desempenho econômico dos Estados e das organizações (públicas e/ou privadas; internas e/ou externas) atuantes neste ambiente. 
Já a TBR busca entender como as firmas obtêm vantagens competitivas sustentáveis; isto é, vantagens que perduram ao longo do tempo sobre seus concorrentes. A principal preocupação da TBR é entender quais recursos estratégicos (valioso, raros, inimitáveis e organizáveis) a firma deve possuir de forma a lhe permitirem obter rendas ricardianas (BARNEY, CLARK, 2007).

Com base nestas duas teorias foi possível levantar cinco hipóteses de pesquisa, sendo as três primeiras relativas ao ambiente institucional e as duas últimas relativas aos recursos:

h1: Direitos de Propriedade (Força Legal) bem definidos atraem maiores volumes de IED.

h2: A Ausência de Corrupção (Força Política) atrai maiores volumes de IED.

h3: A Liberdade de Investimento (Força Econômica) atrai maiores volumes de IED.

h4: A maior Disponibilidade de Terras Agricultáveis atraem maiores volumes de IED.

h5: Quanto menor for a Produtividade da Terra (rendimento) maior é o potencial de atração de IED.

O problema de pesquisa começou a ser respondido com a análise qualitativa, por meio da metodologia denominada csQCA, a qual é baseada em comparações lógicas entre condicionantes presentes em diferentes casos (RIHOUX, RAGIN, 2009). Por meio do software Tosmana (CRONQVIST, 2003; 2007), foi possível encontrar respostas (resultados lógicos) que explicassem o padrão de inversão ocorrido em 16 países no ano de 2010.

A referida análise csQCA verificou que as variáveis relativas aos recursos estratégicos têm uma pertinência muito elevada na realização de investimentos externos. Ou seja, chegou-se à conclusão de que uma baixa produtividade seria uma condição suficiente para a atração de investimentos pela possibilidade de exploração da "brecha produtiva" subutilizada nos países receptores. Concluiu-se, também, que a presença de grande disponibilidade de terras é uma condição estratégica para a atração de investimento, quando considerados os 16 países da amostra. Contudo vale destacar que os resultados não podem ser generalizados devido às premissas da própria metodologia (que analisa o padrão lógico de cada caso em particular), o recorte estanque apenas no ano de 2010 e a existência de um grande número de contradições [C] nos resultados (nove em 16 casos). 
$\mathrm{Na}$ sequência, procederam-se as análises quantitativas, fundamentadas em oito modelos de dados em painel (quatro de efeito aleatório e quatro de efeito fixo). Tal metodologia é considerada adequada, porque permite uma avaliação longitudinal dos determinantes do IED, de forma a evitar problemas de endogeneidade ou de falta de variáveis instrumentais (HAMILTON, NICKERSON, 2001).

Neste modelo constatou-se que, quanto melhor um ambiente institucional salvaguardar direitos de propriedade, maiores serão os volumes de IED por ele recebido, principalmente, em decorrência da capacidade existente neste ambiente institucional, de garantir aos investidores que a renda potencial de suas aplicações em terra seja por eles realizada (FOSS, FOSS, 2005; KIM, MAHONEY, 2007). Ademais, os modelos demonstraram que a disponibilidade de terras agricultáveis se mostra determinante na atração de IED à medida que se torna mais escassa e, portanto, mais valiosa.

Por fim, as evidências apresentadas nos estudos em profundidade da experiência moçambicana e brasileira permitiram ao leitor observar como os investimentos estão ocorrendo em diferentes ambientes institucionais, e como os ambientes institucionais (moçambicano e brasileiro) estão reagindo a estes investimentos. Pelas duas experiências analisadas pode-se verificar a importância da existência de direitos de propriedade bem definidos, e ambientes institucionais com regras claras sobre estes direitos, de modo a evitarse problemas de seleção adversa tanto ex ante quanto ex post. Ademais, os casos reforçam a pertinência que a existência de corrupção em ambos os Estados atua como "facilitador" para a ocorrência do IED nas terras agricultáveis destas nações.

Sumarizando, explicita-se um quadro com os resultados da análise quantitativa e sua correspondência com cada hipótese levantada pelas teorias (vide Quadro 3). 
Quadro 3 - Hipóteses e Resultados das Análises

\begin{tabular}{|c|c|c|c|c|}
\hline $\begin{array}{c}\text { Hipóteses para Maior Atração } \\
\text { de IED } \\
\end{array}$ & $\begin{array}{c}\text { Sinal } \\
\text { Esperado } \\
\end{array}$ & $\begin{array}{c}\text { Quantitativa } \\
\text { Painéis }\end{array}$ & $\begin{array}{c}\text { Resultado } \\
\text { Final }\end{array}$ & $\begin{array}{c}\text { Avaliação da } \\
\text { Hipótese }\end{array}$ \\
\hline $\begin{array}{l}h 1 \text { : Direitos de Propriedade } \\
\text { (Força Legal) }\end{array}$ & + & + & + & Corroborada \\
\hline $\begin{array}{l}\text { h2: Ausência de Corrupção } \\
\text { (Força Política) }\end{array}$ & + & $\varnothing$ & $\varnothing$ & Rejeitada (não sig.) \\
\hline $\begin{array}{l}\text { h3: Liberdade de investimento } \\
\text { (Força Econômica) }\end{array}$ & + & $\varnothing$ & $\varnothing$ & Rejeitada (não sig.) \\
\hline $\begin{array}{l}\text { h4: Disponibilidade de Terras } \\
\text { Agricultáveis }\end{array}$ & + & - & - & Rejeitada (sig.) \\
\hline h5: Produtividade da Terra & - & $\varnothing$ & $\varnothing$ & Rejeitada (não sig.) \\
\hline
\end{tabular}

Fonte: o próprio autor

Pelos resultados, pode-se inferir que o investidor buscará investir em ambientes institucionais que garantam seus direitos de uso e realização do recurso (BARZEL, 1997; FOSS, FOSS, 2005; KIM, MAHONEY, 2007), apesar da presença de corrupção ou com as dificuldades ligadas a liberdade de investimento. Por vezes, estes investidores têm forte poder de barganha (LIPPMAN, RUMELT, 2003), que sobrepõe quaisquer barreiras existentes no ambiente institucional, 'capturando' o Estado e suas instituições, para atenderem a seus interesses particulares (SAES, 1997; STIGLER, 1971). Muito disto pode ser observado nos casos de Moçambique (onde o governo atua como agente fiscalizador e consultor para novos investimentos), e mesmo no Brasil (onde "laranjas" são usados para a aquisição de terras por extranacionais).

Já no que se refere aos recursos, conclui-se que em alguns países, os investidores buscarão ambientes com brechas de produtividade, as quais podem ser exploradas por eles, a fim de obterem rendas superiores, ainda que tais inferências não possam ser amplamente generalizadas dadas as limitações dos resultados obtidos na técnica csQCA. No que se refere à disponibilidade de terras agricultáveis não foi possível chegar-se a uma conclusão definitiva. As análises qualitativas apontam que maiores investimentos ocorreriam em países com maiores disponibilidades de terra, porém as análises quantitativas indicam que é justamente a diminuição gradativa desta disponibilidade que faz com que os investimentos aumentem. Dadas as limitações existentes na análise qualitativa, já mencionadas anteriormente, pode-se inferir de forma contra intuitiva que dentre outras razões, é justamente a diminuição desta disponibilidade (aumento da raridade do recurso) que faz com que os investimentos aumentem, devido o aumento do valor das terras. 
Por fim, pode-se constatar que tanto a literatura presente na NEI quanto na TBR expõem fatores determinantes na atração do investimento externo direto, ainda que hajam variáveis contra intuitivas nos resultados além de variáveis mais pertinentes do que outras para os investidores.

\section{1 - Contribuições, Limitações e Sugestões para Estudos Futuros}

Uma das principais contribuições desse estudo foi o uso de uma nova abordagem estatística para o tratamento de dados qualitativos que permitiram obter relações entre os determinantes do investimento externo direto em terras nos países em desenvolvimento. Além de servir de modelo para a realização de outras pesquisa institucionais comparativas com informações qualitativas, outra importante contribuição foi o questionamento da lógica institucional, ao verificar-se que a captura do Estado pode levar à seleção adversa dos investimentos. Esse achado, que merece maior aprofundamento, pode ser importante na formação de políticas públicas capazes de trazerem desenvolvimento econômico aos Estados e suas populações.

O estudo encontra limitações principalmente no recorte efetuado. A amostra de países da América Latina e África Sub Saariana ${ }^{63}$ com uma variabilidade ao longo de onze anos pode mostrar-se insatisfatória para inferências generalizantes. Ademais, questões metodológicas relativas a problemas como presença de contradições nas análises csQCA; e de baixa variabilidade e não consideração de simultaneidade nos modelos de painel de efeito fixo consistem também em importantes limitações do estudo.

Por fim, apresentam-se como sugestões para estudos futuros a ampliação da pesquisa de campo com a presença de mais estudos em profundidade, bem como a busca pela atualização dos dados, e formulação de novos modelos e hipóteses que, ao serem testadas, contribuam

\footnotetext{
${ }^{63}$ Havendo sido incluídos de 51 a 69 países nos modelos quantitativos de painel de dados.
} 
para o melhor entendimento desse fenômeno e para o desenvolvimento destas localidades e de seus cidadãos. 


\section{REFERÊNCIAS BIBLIOGRÁFICAS}

ALSTON, L.; EGGERTSSON, T.; NORTH, D. Empirical Studies in Institutional Change. 1st. ed. Cambridge: Cambridge University Press, 1996.

AMAL, M.; SEABRA, F. Determinantes do Investimento Direto Externo (IDE) na América Latina : Uma Perspectiva Institucional. Economia, v. 8, n. 2, p. 231-247, 2007.

AOKI, M. Endogenizing institutions and institutional changes. Journal of Institutional Economics, v. 3, n. 01.

BACEN. Dados sobre Investimentos Estrangeiros Diretos no Brasil. Disponível em: $<$ http://www.bcb.gov.br/rex/ied/port/ingressos/htms/index3.asp?idpai=INVEDIR>. Acesso em: 26 jul. 2012.

BANCO MUNDIAL. Rising global interest in farmland: can it yield sustainable and equitable benefits? Methodology. World Bank Publications. Washington DC, setembro de 2010.

BARNEY, J. B. Firm resources and sustained competitive advantage. Journal of management, v. 17, n. 1, p. 99, 1991.

BARNEY, J. B.; CLARK, D. N. Resource-Based Theory Creating and Sustaining Competitive Advantages. 1st. ed. Oxford, New York: Oxford University Press, 2007.

BARZEL, Y. Economic analysis of property rights. 2nd. ed. Cambridge: Cambridge University Press, 1997.

BRASIL. Lei n. 4.504, de 30 de novembro de 1964. Dispõe sobre o estatuto da Terra e dá outras providências. Disponível em: <http://www.planalto.gov.br/ccivil_03/leis/L4504.htm>. Acesso em: 26 jul. 2012.

Lei n. 5.709, de 7 de outubro de 1971. Regula a Aquisição de Imóvel Rural por Estrangeiro Residente no País ou pessoa Jurídica Estrangeira Autorizada a Funcionar no Brasil, e dá outras Providências. Disponível em: < http://www.planalto.gov.br/ccivil_03/leis/L5709.htm>. Acesso em: 26 jul. 2012. 
Lei n. 6.746, de 10 de dezembro de 1979. Altera o disposto nos arts. 49 e 50 da Lei n.4504, de 30 de novembro de 1964 (Estatuto da Terra), e dá outras providências. Disponível em: <http://www.planalto.gov.br/ccivil_03/leis/1970-1979/L6746.htm>. Acesso em: 26 jul. 2012.

Advocacia-geral da União. Parecer no LA - 01/2010. Brasília: AGU. Disponível em:<http://www.agu.gov.br/sistemas/site/PaginasInternas/NormasInternas/AtoDetalhado.aspx ?idAto=258351\&ID_SITE $>$. Acesso em 27 jul. 2012.

Constituição da República Federativa do Brasil: promulgada em 5 de outubro de 1988. Organização do texto: Juarez de Oliveira. 4. ed. ed. São Paulo: Saraiva, 1990. (Série Legislação Brasileira)., 1988.

BROUSSEAU, E.; RAYNAUD, E. Climbing the Hierarchical Ladders of Rules: the Dynamics of Institutional Framework. En: 11TH annual conference international society for new institutional economics (ISNIE) 21-23 jun. 2007. Anais. Reykjavík. 2007.

BROUSSEAU, E.; SCHEMEIL, Y.; SGARD, J. Constitutions, States and Development. October. 2009, Paris. Disponível em: $<$ http://www.ie.ufrj.br/datacenterie/pdfs/seminarios/pesquisa/texto0704.pdf>, Acesso em 03 mar.2013.

CASSON, M. An Entrepreneurial Theory of the Firm. In: Foss, N.; Volker, M. (Eds.) Competence, governance, and entrepreneurship: advances in economic strategy research. New York, Oxford: Oxford University Press, 2005.

CEPAGRI. Dados sobre processo de aplicação de projeto e direito à terra em Moçambique. Dados. Maputo: CEPAGRI, 2011.

CLEEVE, E. The Eclectic Paradigm and Foreign Direct Investment in Sub- Saharan Africa. Em: 10TH Annual Conference IAABD. Anais. 2009.

CPI. Dados sobre investimentos aprovados por setor 2009. Dados. Maputo: CPI, 2009.

CRONQVIST, L. Presentation of TOSMANA. Louvain-La-Neuve and Leuven. 2003.

CRONQVIST, L. Tosmana - TOol for SMAll-N Analysis Version 1.3 beta. Comparative and General Pharmacology. Working Paper, 2007. 
CÂMARA DOS DEPUTADOS. Relatório da Subcomissão destinada a, no prazo de 180 dias, analisar e propor medidas sobre o processo de aquisição de áreas rurais e suas utilizações, no Brasil, por pessoas físicas e jurídicas estrangeiras - SUBESTRA. Disponível em: <http://www2.camara.gov.br/atividade -legisl ativa/comissoes/comissoespermanentes/capadr/subcomissoes/subestra-relatorio-aprovado>. Acesso em: 13 jun. 2012.

DAHL, R. A. Poliarquia. 1st. ed. São Paulo: ed. USP, 1997.

DAVISON, W. Ethiopia Says It May Grant Additional Land to Karuturi Global. Bloomberg, v. 05 may, 2011.

DUNNING, J. H. The Eclectic (OLI) Paradigm of International Production: Past, Present and Future. International Journal of the Economics of Business, v. 8, n. 2, p. 173-190, doi:10.1080/13571510110051441, 2001.

DYER, J. H.; SINGH, H. The relational view: Cooperative strategy and sources of interorganizational competitive advantage. Academy of Management Review, 23(4), pp. 660679, 1998.

FAO. FAO statistical yearbook 2010. Disponível em: <http://www.fao.org/economic/ess/ess-publications/ess-yearbook/ess-yearbook2010/en/>. Acesso em: 7 set. 2011.

FAO. Trends and Impacts of Foreign Investment in Developing Country Agriculture. . Roma. Disponível em: 〈http://www.maff.go.jp/j/kokusai/kokkyo/toushi/pdf/faoeibun1.pdf>, 2012a.

FAO. The State of Food and Agriculture 2012. Roma. 2012b.

FOOD: THE SILENT TSUNAMI. The Economist, p. 1-2, 2008.

FOSS, K.; FOSS, N. J.; KLEIN, P. G.; KLEIN, S. K. The Entrepreneurial Organization of Heterogeneous Capital. Journal of Management Studies, v. 44, n. 7, p. 1165-1186, doi:10.1111/j.1467-6486.2007.00724.x, 2007.

FOSS, K.; FOSS, N. J. Resources and transaction costs: how property rights economics furthers the resource-based view. Strategic Management Journal, v. 26, n. 6, p. 541-553, doi:10.1002/smj.465, 2005. 
HAMILTON, B. H.; NICKERSON, J. A. Correcting for Endogeneity in Strategic Management. Working Paper. 2001.

HANNEMANN, G. Novo “ rei da soja ” no Brasil é argentino. Folha de São Paulo, v. 21 aug., n. Mercado, 2011.

HEAD, B. For South Korea, it is 99 years of farming. Daily Nation, v. 11 Jan, 2009.

HERITAGE FOUNDATION. Investment Freedom, Index of Economic Freedom. Disponível em: <http://www.heritage.org/index/investment-freedom>. Acesso em: 23 ago. 2011a.

HERITAGE FOUNDATION. Property Rights, Index of Economic Freedom. Disponível em: <http://www.heritage.org/index/Property-Rights>. Acesso em: 23 ago. 2011b.

HERITAGE FOUNDATION. Freedom from Corruption, Index of Economic Freedom. Disponível em: <http://www.heritage.org/index/Freedom-from- Corruption>. Acesso em: 23 ago. 2011c.

HUNT, E. K. História do Pensamento Econômico. 2 ed ed. Rio de Janeiro: Elsevier/Campus, 2005.

KHAN, S. Farmland investment fund is seeking more than Dh 1bn. The National, v. 12 sept., 2009.

KEYNES, J. M. Teoria Geral do Emprego, do Juro e da Moeda; Inflação e Deflação. São Paulo: Abril Cultural, (Os Economistas), 1983.

KIM, J.; MAHONEY, J. T. Appropriating economic rents from resources: an integrative property rights and resource-based approach. International Journal of Learning and Intellectual Capital, v. 4, n. 1/2, p. 11-28, 2007.

LAZZARINI, S. G. Capitalismo de laços: os donos do Brasil e suas conexões. Campus/Elsevier, 2011.

LIJPHART, A. Modelos de democracia; desempenho e padrões de governo em 36 países. Rio de Janeiro: Civilização Brasileira, 2003 
LIPPMAN, S. A.; RUMELT, R. P. A bargaining perspective on resource advantage. Strategic Management Journal, v. 24, n. 11, p. 1069-1086, doi:10.1002/smj.345, 2003.

LIPSET, S. M. Political Man: The Social Bases of Politics. New York: Doubleday, 1960.

MOÇAMBIQUE. Artigo 21 da Lei $n^{0} 3$ de 24 de Junho de 1993. Lei de Investimentos. Legislação sobre investimentos, 1993.

MUJICA DIJO QUE EN SU GOBIERNO NO SE VENDERÁN TIERRAS A OTROS PAÍSES. El País, 2010.

NORTH, D. C. Institutions, Economic Growth and Freedom: An Historical Introduction,' in M.A. Walker (Ed) Freedom Democracy and Economic Welfare I,. Em: INTERNATIONAL SYMPOSIUM, VANCOUVER: THE FRASER INSTITUTE. Anais. Vancouver. 1986.

NORTH, D. C. Institutions, Institutional Change and Economic Performance. First ed. Cambridge: Cambridge University Press, 1990.

NORTH, D. C.; WALLIS, J. J.; WEINGAST, B. R. Violence and Social Orders. First ed. New York: Cambridge University Press, 2009.

OCDE. OCDE-FAO Agricultural Outlook 2009-2018. . Paris. Disponível em: <http://www.fao.org/es/esc/common/ecg/599/en/OECD_Highlights.pdf>, 2009.

PETERAF, M. A. The Cornerstone of Competitive Advantage: A Resource-Based View. Strategic Management Journal, v. 14, n. 3, p. 179-191, 1993.

PIERPONT, B. Democracy, Property Rights and FDI in Developing Countries A Regional Analysis. Working Paper, 2007.

PNUD. Relatório de Desenvolvimento Humano 2010 Edição do $20^{\circ}$ Aniversário A Verdadeira Riqueza das Nações: Vias para o Desenvolvimento Humano. New York: Programa das Nações Unidas para o Desenvolvimento, 2010.

PRAHALAD, C. K. A riqueza na base da pirâmide. Porto Alegre: Bookman, 2005. p. 391

PRETTO, J. M. Imóveis rurais sob propriedade de estrangeiros no Brasil. Brasília. Disponível em: <http://coptec.org.br/biblioteca/Realidade Brasileira/Artigos/terras na mao de ESTRANGEIROS-pretto.pdf>, 2009. 
REYDON, B. P. Mercados de Terras Agrícolas e Determinantes de seus Preços no Brasil: Um Estudo de Casos. UNICAMP - Campinas. 1992.

REYDON, B. P.; CORnÉliO, F. N. M. Mercados de Terra no Brasil Estrutura e Dinâmica. Brasília: PCT MDA/IIAC, 2006.

REYDON, B. P.; FERNANDES, V. B. Land Grab ou Aquisição de terras: lições partindo da América Latina e do Brasil. Working Paper, 2012.

RICARDO, D. Princípios de Economia Política e Tributação. Terceira e ed. São Paulo: Nova Cultural Ltda., 1996.

RIHOUX, B.; RAGIN, C. C. Configurational Comparative Methods Qualitative Comparative Analysis (QCA) and Related Techniques. Applied So ed. London and Thousand Oaks: SAGE Publications, Inc., 2009.

ROBBINS, L. An Essay on the Nature and Significance of Economic Science. 2 Edition ed. London: Macmillan, 1945.

SAES, M. S. M. A racionalidade econômica da regulamentação no mercado brasileiro de café. $1^{\text {a }}$ edição ed. São Paulo: ANNABLUME/ FAPESP, 1997.

SCHUMPETER, J. A. Capitalismo, Socialismo, Democracia. Rio de Janeiro: Fundo de Cultura, 1961.

SERVEN, L.; SOLIMANO, A. Debt Crisis, Adjustment Policies and Capital Formation in Developing Countries: Where Do We Stand? World Development, v. 21, n. 1, p. 127-140, 1993.

STIGLER, G. J. The Theory of Economic Regulation. Journal of Economics and Management Science, v. 2, n. 1, p. 3-21, 1971.

THE CHINESE AND ARABS ARE BUYING POOR COUNTRIES' FARMS ON A COLOSSAL SCALE. BE WARY OF THE RESULTS. The Economist, 2009.

UNAC JUSTIÇA AMBIENTAL. Os senhores da terra, Análise Preliminar do fenômeno de usurpação de terras em Moçambique. Maputo. 2011. 
WERNERFELT, B. A resource-based view of the firm. Strategic Management Journal, v. 5, n. 2, p. 171-180, doi:10.1002/smj.4250050207, 1984.

The Resouce-Based View of teh Firm: Ten Years After. Strategic Management Journal, v. 16, n. 3, p. 171-174, 1995.

WHATEVER HAPPENED TO THE FOOD CRISIS? Whatever happened to the food crisis? The Economist, 2009.

WILKINSON, J.; REYDON, B.; SABBATO, A. Dinâmica do mercado de terras na América Latina: o caso do Brasil. Santiago: FAO/Escritório Regional, dezembro de 2010

WILliAMSON, O. E. The Economic Institutions of Capitalism: Firms, Markets, Relations, Contracting. New York: The Free Press, 1985. v. 98 Strategizing, Economizing, and Economic Organization. Strategy Management Journal, v. 12, n. Fundamental Research Inssues, p. 75-94, 1991.

—. The Mechanisms of Governance. New York, Oxford: Oxford University Press, 1996. p. 442 - The New Institutional Economics: Taking Stock, Looking Ahead. Journal of Economic Literature, v. XXXVIII, n. September, p. 595-613, 2000. Transaction Cost Economics: The Precursors. Economic Affairs, 2008.

WOOLDRIDGE, J. M. Introdução à Econometria, uma abordagem moderna. $5^{\mathrm{a}}$ ed ed. São Paulo: Pioneira Thomson Learning, 2006. 


\section{ANEXO 1 \\ Anexo 1 - Premissas Metodológicas: Técnica csQCA e Software Tosmana}

A ideia fundamental da análise comparativa qualitativa crip-set (cs-QCA) está em desenvolver 'pontos de inflexão' que possibilitem distinguir os casos analisados, transformando-os em variáveis dicotômicas; ou seja, transformando-os em álgebra Booleana. Por meio deste recurso, consegue-se realizar comparações lógicas entre os casos por meio de expressões, nas quais o "1" (um) representa a presença da variável a ser analisada e o "0" (zero) representa sua ausência. Dessa forma, é possível verificar a existência de condições suficientes e/ou necessárias para se alcançar um determinado Outcome [O].

Uma das críticas a esta forma de representação, ou simplificação, reside no fato de que o uso da álgebra Booleana, apesar de não gerar perdas significantes na precisão dos dados, depende muito da clareza, transparência e justificativa teórica para a definição dos 'pontos de inflexão'. Pode-se afirmar que o grande desafio que o pesquisador encontra nesta metodologia está na definição clara e justificada de limiares não artificiais, os quais possam segregar os dados de maneira fidedigna as premissas teóricas.

Conforme já ressaltado, a técnica cs-QCA utiliza a álgebra Booleana transformando todas as variáveis em dummies, inclusive a variável resultado (Outcome). Assim sendo, o resultado do modelo se constitui por meio das expressões lógicas baseadas em operações matemáticas simples, a saber:

"E” lógico representado por [*]

“Ou” lógico representado por $[+]$

Com esta linguagem básica, é possivel construir sentenças lógicas e elaborar complexas gamas de operações (RIHOUX, RAGIN, 2009). Em seu livro, Rihoux e Ragin (2009) apresentam alguns exemplos:

$$
\mathrm{R} * \mathrm{~B} * \mathrm{I}+\mathrm{R} * \mathrm{~B} * \mathrm{i} \rightarrow \mathrm{O}
$$


A expressão acima significa que: a presença de $\mathrm{R}$, combinada com a presença de $\mathrm{B}$, combinada com a presença de I; $\mathrm{Ou}$, a presença de $\mathrm{R}$, combinada com a presença de $\mathrm{B}$; combinada com a ausência de I; leva ao resultado O.

Isto é:

Note-se que não importa o resultado $(1,0)$ de $\mathrm{I}$, se ocorrerem as condições $\mathrm{R}$ e $\mathrm{B}$ sempre ocorrerá o resultado $\mathrm{O}$. Pode-se inferir, portanto, que:

\section{$\mathrm{R} * \mathrm{~B} \rightarrow \mathrm{O}$ (expressão reduzida)}

Portanto, para que se consiga enxergar as expressões lógicas advindas da análise do software, requer-se a construção uma tabela dicotômica de dados como base das análises. Contudo, é importante compreender como análisar os resultados decorrentes do modelo. Abaixo apresenta-se a Tabela 8, que visa explicar melhor como o modelo opera.

\section{Tabela 8 - Explicação para as Expressões Lógicas}

$\mathbf{O}=\mathbf{A} * \mathbf{C}+\mathbf{B} * \mathbf{c}$ (nenhuma das condições é necessária ou suficiente por si só para que o resultado seja atingido; implica diferentes combinações de mais de uma condição);

$\mathbf{O}=\mathbf{A} * \mathbf{C}+\mathbf{B} * \mathbf{C}$ (neste caso, $\mathbf{C}$ é uma condição necessária uma vez que ocorre em duas combinações possíveis da sequência, mas não é por si suficiente para $\mathrm{O}$, tal como deve ser combinada com outras condições);

$\mathbf{O}=\mathbf{A} * \mathbf{C}$ (Nesta situação, ambas A e C são necessárias, mas não suficientes por si sós, elas devem ser combinadas para formarem uma condição suficiente, dessa forma pode-se dizer que A e C são condições "estratégicas");

$\mathbf{O}=\mathbf{A}+\mathbf{B} * \mathbf{c}$ (aqui A é suficiente mas não é necessária, uma vez que a combinação $\mathrm{B} * \mathrm{c}$ também conduz a um resultado $\mathrm{O}$ );

$\mathbf{O}=\mathbf{B}$ (neste caso, B é necessária e, ao mesmo tempo suficiente para alcançar O). 